



\section{Ontwikkeling van een rekentool om de ammoniakemissie uit vleeskuikenstallen te kunnen voorspellen}

Andre Aarnink, Jan van Harn, Klaas Banken en Nico Ogink

Dit onderzoek is uitgevoerd door Wageningen Livestock Research, in opdracht van en gefinancierd door het Ministerie van Economische Zaken, in het kader van het Beleidsondersteunend onderzoek thema 'Agro - Programma Stikstof' (projectnummer BO-20-004-022).

Wageningen Livestock Research

Wageningen, november 2016

Rapport 990 
Aarnink, A.J.A., J. van Harn, K. Blanken en N.W.M. Ogink, 2016. Ontwikkeling van een rekentool om de ammoniakemissie uit vleeskuikenstallen te kunnen voorspellen. Wageningen Livestock Research, Rapport 990 blz. 72.

\section{Samenvatting}

Wageningen Livestock Research heeft gedurende vier ronden onderzoek uitgevoerd naar het effect van voersamenstelling op de strooiselkarakteristieken (drogestofgehalte, stikstofgehalte,

ammoniumgehalte, $\mathrm{pH}$, temperatuur en rulheid) en de ammoniakemissie uit vleeskuikenstallen. Het doel van dit onderzoek was enerzijds meer inzicht te verkrijgen in de relaties tussen voersamenstelling, strooiselkarakteristieken en ammoniakemissie en anderzijds het ontwikkelen en valideren van een ammoniakemissie rekentool/-model voor vleeskuikens. In dit rapport worden de resultaten van dit onderzoek en de ontwikkelde ammoniakemissie rekentool beschreven.

\section{Summary}

Wageningen Livestock Research performed a study in which the effect of feed composition on litter characteristics ( $\mathrm{pH}$, temperature, dry matter, nitrogen and ammonium content) and ammonia emission was investigated. The objective of this study was to gain knowledge in the relationships between feed composition, litter characteristics and ammonia emission from broiler houses. Based on this knowledge an ammonia emission model was developed and validated. This report describes the results of the experimental research and the developed ammonia emission model.

Dit rapport is gratis te downloaden op http://dx.doi.org/10.18174/397953

of op www.wur.nl/livestock-research (onder Wageningen Livestock Research publicaties).

\section{(C) 2016 Wageningen Livestock Research}

Postbus 338, 6700 AH Wageningen, T 03174839 53, E info.livestockresearch@wur.nl, www.wur.nl/livestock-research. Wageningen Livestock Research is onderdeel van Wageningen University \& Research.

Wageningen Livestock Research aanvaardt geen aansprakelijkheid voor eventuele schade voortvloeiend uit het gebruik van de resultaten van dit onderzoek of de toepassing van de adviezen.

Alle rechten voorbehouden. Niets uit deze uitgave mag worden vermenigvuldigd en/of openbaar gemaakt worden door middel van druk, fotokopie, microfilm of op welke wijze dan ook zonder voorafgaande toestemming van de uitgever of auteur.

De certificering volgens ISO 9001 door DNV onderstreept ons kwaliteitsniveau. Op als onze onderzoeksopdrachten zijn de Algemene Voorwaarden van de Animal Sciences Group van toepassing. Deze zijn gedeponeerd bij de Arrondissementsrechtbank Zwolle. 


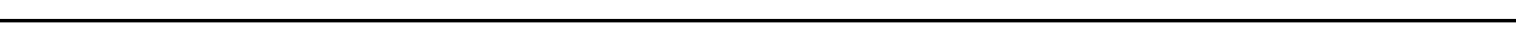




\section{Inhoud}

$\begin{array}{lr}\text { Woord vooraf } & 5\end{array}$

$\begin{array}{ll}\text { Samenvatting } & 7\end{array}$

$\begin{array}{llr}1 & \text { Inleiding } & 9\end{array}$

$\begin{array}{lll}1.1 & \text { Algemeen } & 9\end{array}$

$\begin{array}{lll}1.2 & \text { Doelstelling } & 9\end{array}$

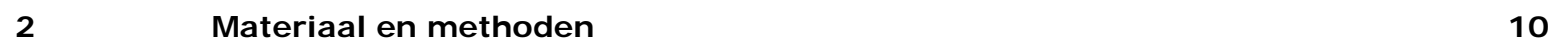

$\begin{array}{lll}2.1 & \text { Algemeen } & 10\end{array}$

$\begin{array}{lll}2.2 & \text { Materiaal } & 10\end{array}$

2.2.1 Accommodatie 10

2.2.2 Diermateriaal 10

2.2.3 Proefbehandelingen 11

2.2.4 Verlichting 13

2.2.5 Klimaat 13

2.2.6 Entingen 13

2.2.7 Strooisel 13

$\begin{array}{lll}2.3 & \text { Methoden } & 14\end{array}$

$\begin{array}{ll}\text { 2.3.1 Waarnemingen } & 14\end{array}$

$\begin{array}{ll}\text { 2.3.2 Statistische analyse } & 17\end{array}$

$3 \quad$ Resultaten en discussie $r$

$\begin{array}{lll}3.1 & \text { Voer } & 19\end{array}$

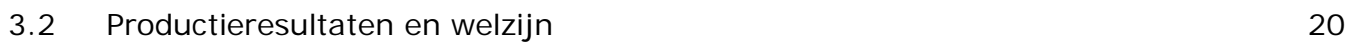

3.2.1 Effect kaliumgehalte $\quad 20$

$\begin{array}{ll}3.2 .2 \text { Effect eiwitgehalte } & 23\end{array}$

$\begin{array}{lll}3.3 & \text { Feces- en strooiselsamenstelling } & 24\end{array}$

$\begin{array}{llr}4 & \text { Beschrijving rekentool } & 28\end{array}$

4.1 Gewichtsverloop vleeskuikens en voer en wateropname 30

4.2 Hoeveelheid en samenstelling van de uitgescheiden mest 33

$\begin{array}{lll}4.3 & \text { Processen in het strooisel } & 41\end{array}$

4.4 Berekening van de ammoniakemissie $\quad 45$

$\begin{array}{llr}5 & \text { Algemene discussie } & 48\end{array}$

$6 \quad$ Conclusies $r 51$

$7 \quad$ Aanbevelingen $\quad 52$

$\begin{array}{lr}\text { Literatuur } & 53\end{array}$ 
Bijlage 1 Samenstelling basismelen start- en groei-/ eindvoeders in ronde 1 en 2

Bijlage 2 Samenstelling voeders ronde 3

Bijlage 3 Voersamenstelling (ronde 4)

57

Bijlage 4 Klimaatinstellingen

59

Bijlage 5 Gerealiseerde temperaturen, relatieve luchtvochtigheden en ventilatiedebieten per klimaatcel

Bijlage 6 Werkwijze boxmetingen project 4413801750 'Strooiselkwaliteit' Klimaatstal DB-CVI

67

Bijlage 7 Productieresultaten per voerprogramma (Ronde 3 en 4) 


\section{Woord vooraf}

In het kader van de Programmatische Aanpak Stikstof (PAS) wordt de inzet van voer- en managementmaatregelen en aanvullende technische maatregelen voorbereid. Het gaat hierbij om maatregelen die leiden tot minder ammoniakemissie uit de veehouderij via voer- en/of managementmaatregelen. Binnen dit kader is een onderzoek uitgevoerd waarbij de relatie tussen de strooiselkarakteristieken (drogestofgehalte, $\mathrm{pH}$, temperatuur, stikstof- en ammoniumstikstofgehalte) en de ammoniakemissie is onderzocht. Doelstelling van dit onderzoek was enerzijds het vaststellen van de relatie tussen strooiselkarakteristieken en ammoniakemissie en anderzijds het ontwikkelen en valideren van een ammoniakemissie rekentool/-model voor vleeskuikens. In het voor u liggende rapport worden de resultaten van het experimenteel onderzoek met vleeskuikens beschreven waarbij de relatie tussen strooiselkarakteristieken en ammoniakemissie werd onderzocht. Daarnaast wordt in dit rapport tevens het ontwikkelde ammoniakemissiemodel beschreven.

Dit onderzoek is uitgevoerd en gefinancierd binnen het beleidsondersteunende onderzoek thema "Agro - Programma Stikstof" (projectnummer BO-20-004-022) van het Ministerie van Economische Zaken. De auteurs bedanken Saskia Burgers van PRI-Biometris voor de statistische ondersteuning, Peter Groot Koerkamp voor zijn inbreng bij de totstandkoming van het rekenmodel en de dierverzorgers van DB-CVI.

Dr.ir. N.W.M. Ogink

Coördinator Beleidsondersteunend Onderzoek 


\section{Samenvatting}

Wageningen Livestock Research heeft onderzoek uitgevoerd naar het effect van het stalklimaat en het drogestofgehalte van de uitgescheiden mest op de strooiselkarakteristieken ( $\mathrm{pH}$, temperatuur, drogestof-, stikstof- en ammoniumgehalte en rulheid van het strooisel) en de ammoniakemissie. Het doel van dit onderzoek was enerzijds inzicht te verkrijgen in de relaties tussen omgevingsklimaat, mest- en strooiselkarakteristieken en ammoniakemissie en anderzijds het ontwikkelen en valideren van een ammoniakemissie rekentool voor vleeskuikens.

Het onderzoek omvatte in totaal vier volledige vleeskuikenproductieronden in twee klimaatcellen van de klimaatstal van WUR-CVI. In deze klimaatstal is het mogelijk de temperatuur, relatieve luchtvochtigheid en het ventilatiedebiet in de cellen nauwkeurig te regelen. Om verschillen in het drogestofgehalte en/of het ammoniumgehalte van de uitgescheiden mest te creëren werden voeders met een verschillend kalium- en/of eiwitgehalte gebruikt.

In de eerste twee ronden werd het effect van de relatieve luchtvochtigheid van de stallucht en het ventilatiedebiet onderzocht. Daarnaast werden, om verschillen in het drogestofgehalte van de uitgescheiden mest te creëren, voeders met een verschillend kaliumgehalte (K-gehalte) verstrekt (range: 8 - $11 \mathrm{~g} \mathrm{~K} / \mathrm{kg}$ voer). Aangezien in de eerste twee ronden het drogestofgehalte van het strooisel heel laag was, zijn in ronde 3 en 4 aanvullende metingen gedaan met lagere K-gehalten van het voer. De resultaten van ronde 4 zijn vooral gebruikt voor kalibratie van de modelparameters, terwijl de resultaten van alle ronden zijn gebruikt voor validatie van het model.

In elke klimaatcel werden 8 grondhokken (oppervlak: 1,5 $\mathrm{m}^{2}$ ) met strooisel (witte houtkrullen: 2 $\mathrm{kg} / \mathrm{m}^{2}$ ) geplaatst, d.i. 16 hokken in totaal. In elk hok werden 25 vleeskuikenhaantjes van een commerciële herkomst opgezet ( 17 kuikens $/ \mathrm{m}^{2}$ ); per ronde werden dus (16 hokken $\times 25$ dieren=) 400 vleeskuikenhanen gebruikt. De lengte van de productieperiode bedroeg in de eerste drie ronden 35 dagen, de vierde productieperiode omvatte het leeftijdstraject 0 - 42 dagen.

De eerste drie dagen werd de stal continu verlicht, daarna werd tot het einde van de ronde een dag/nacht schema gehanteerd van 18 uur licht en 6 uur donker per etmaal (18L:6D). In het onderstaande schema wordt de proefopzet van alle ronden schematisch weergegeven.

\begin{tabular}{|c|c|c|c|c|}
\hline & Ronde 1 & Ronde 2 & Ronde 3 & Ronde 4 \\
\hline Lengte productieronde (dagen) & 35 & 35 & 35 & 42 \\
\hline Aantal dieren & 400 & 400 & 400 & 400 \\
\hline Aantal hokken & 16 & 16 & 16 & 16 \\
\hline Relatieve luchtvochtigheid (\%) & 50 en 70 & 50 & 50 en 60 & 50 \\
\hline $\begin{array}{l}\text { Ventilatiedebiet }\left(\mathrm{m}^{3} / \mathrm{kg} \text { levend }\right. \\
\text { gewicht) }\end{array}$ & 1 en 2 & 1 & 1 & 1 \\
\hline Kaliumgehalte $(\mathrm{g} / \mathrm{kg})$ & $8,9,10$ en 11 & $8,9,10$ en 11 & 7 en 8,5 & 7 en 9 \\
\hline Ruw eiwitgehalte $(\mathrm{g} / \mathrm{kg})$ & normaal & normaal & normaal en hoog & normaal en laag \\
\hline
\end{tabular}

Naast het vaststellen van de effecten op de productieparameters (groei, voerverbruik, waterverbruik voerconversie en uitval) en de ernst en voorkomen van hakdermatitis en voetzoollaesies werd op 20/21, 27/28 en 34/35 dagen leeftijd de ammoniakemissie bepaald via de zogenaamde dynamische box methode. In de vierde ronde werd naast deze tijdstippen ook nog op 41/42 dagen leeftijd de ammoniakemissie bepaald. 
Naast de ammoniakemissie werden op deze dagen de volgende strooiselkarakteristieken vastgesteld: $\mathrm{pH}$, temperatuur, drogestof-, totaal stikstof- en ammoniumstikstofgehalte.

Uit de analyse van de resultaten van de experimenten en uit de modelberekeningen en -validatie kunnen we het volgende concluderen:

- $\mathrm{Er}$ is een grote variatie in de ammoniakemissie tussen de verschillende ronden. Het grootste verschil in ammoniakemissie was tussen ronden 3 en 4 . De ammoniakemissie in ronde 3 was bijna een factor 10 hoger dan in ronde 4. Deze verschillen konden slechts voor een deel worden verklaard met de huidige variabelen in het model (ammoniumgehalte, $\mathrm{pH}$, temperatuur, luchtsnelheid (ventilatiedebiet) en rulheid van het strooisel).

- Het eiwit- en het K-gehalte hadden geen significant (lineair) effect op de ammoniakemissie.

- Van de variabelen die, naar verwachting, de emissie vanuit de bron (het strooisel) beïnvloeden hebben de $\mathrm{pH}$ (regressiecoëfficiënt (r.c.) $=0.250$ (s.e. 0.072); $\mathrm{P}<0.001$ ), rulheid van het strooisel (r.c. $=0.112$ (s.e. 0.020); P<0.001) en het box-debiet (luchtsnelheid over het emitterend oppervlak; r.c. $=0.0223$ (s.e. 0.0039); $\mathrm{P}<0.001$ ) de sterkste invloed op de ammoniakemissie. De effecten van temperatuur (r.c. $=0.075$ (s.e. 0.035); $P=0.032$ ) en Ntot-gehalte (r.c. $=-0.030$ (s.e. 0.017); $\mathrm{P}=0.078$ ) van het strooisel zijn minder sterk. Het effect van $\mathrm{NH4-N}$-gehalte was niet significant ( $r . c$. $=0.052$ (s.e. 0.060); $P=0.383$ ).

- Een hoger K-gehalte in het voer heeft een negatief effect op de productieresultaten, de strooiselkwaliteit en de voetzoollaesiescore

- Het verstrekken van een voerprogramma met een verhoogd eiwitgehalte, maar met eenzelfde aminozurenpatroon, leidde niet tot een verhoogde wateropname of water/voer verhouding; ook de overige productieresultaten werden hierdoor niet beïnvloed. Het resulteerde wel in een toename van het aantal en ernst van hakdermatitis en voetzoollaesies.

- Het verstrekken van een voerprogramma met een verlaagd eiwitgehalte, maar met eenzelfde aminozurenpatroon, had geen aantoonbaar effect op de productieresultaten. Wel verslechterde de voerconversie enigszins. Het verstrekken van een laag eiwitvoer had geen effect op de ernst en voorkomen van voetzoollaesies en hakdermatitis.

- De ammoniakemissie blijkt met het huidige model nog niet goed voorspeld te kunnen worden. Daarvoor is beter inzicht nodig in de snelheid van urinezuuromzetting en de snelheid waarin de ammoniak vervluchtigt uit het strooisel, mede in afhankelijkheid van de $\mathrm{pH}$ en de rulheid van het strooisel.

Aanbevolen wordt om extra onderzoek te doen naar de snelheid van de urinezuuromzetting in strooisel en deze te relateren aan de karakteristieken van de stal en van de vleeskuikens (o.a. herkomst en broederijomstandigheden). 


\section{$1 \quad$ Inleiding}

\subsection{Algemeen}

In het kader van PAS is er behoefte aan de ontwikkeling van voer- en managementmaatregelen en aanvullende technische maatregelen die worden toegepast om de uitstoot van ammoniak te verminderen (hier verder PAS-maatregelen genoemd). PAS-maatregelen moeten leiden tot minder ammoniakemissie uit de veehouderij via voer- en managementaanpassingen. De PAS-maatregelen zijn hiermee een aanvulling op de mogelijkheden die de bestaande emissiearme huisvestingsmaatregelen in bijlage 1 bij de Regeling ammoniak en veehouderij (Rav) bieden, en staan opgenomen in bijlage 2 van de Rav. De aanvraag en toetsing van deze categorie maatregelen vindt plaats via de Technische adviescommissie Rav.

Voer- en managementmaatregelen kunnen een hele range aan maatregelen omvatten (zie voor de pluimveehouderij o.a. het rapport van Harn et al. (2012). Het gaat hierbij om verschillende typen maatregelen, maar ook om verschillende niveaus binnen een bepaald type maatregel, bijvoorbeeld eiwitgehalte van het voer of gehalte aan verzurende Ca-zouten. Het zou veel tijd en geld kosten om al deze maatregelen en combinaties van maatregelen afzonderlijk te bemeten op de ammoniakemissie. Daarom is het belangrijk om een rekentool/model te ontwikkelen om de effecten van dit type maatregelen en hun gecombineerde toepassing te kunnen schatten.

Hiervoor is kennis / input nodig met betrekking tot welke variabelen de ammoniakemissie kunnen beïnvloeden en in welke richting deze beïnvloeding is. In 2012/2013 is voor pluimvee hiermee een start gemaakt. In een experimenteel onderzoek werd onder gecontroleerde omstandigheden de samenhang tussen het drogestof(ds)-gehalte van de uitgescheiden mest, de strooiselkwaliteit/karakteristieken (ds-gehalte, $\mathrm{pH}$, strooiseltemperatuur, rulheid, totaal stikstof- en ammoniumstikstofgehalte van het strooisel) en de ammoniakemissie bestudeerd. Het ds-gehalte van de uitgescheiden mest werd hierbij gecontroleerd via het kaliumgehalte (K-gehalte) in het voer. Uit dit onderzoek kwamen een aantal relaties tussen strooiselkarakteristieken drogestof- en ammoniumgehalte en $\mathrm{pH}$, en de ammoniakemissie naar voren (Van Harn e.a., 2014). De range in dsgehalte van strooisel in dit experimentele onderzoek kwam niet geheel overeen met de range zoals die in de praktijk wordt waargenomen. In dit experimentele onderzoek werd met name gemeten bij lagere ds-gehalten. Derhalve is het belangrijk te onderzoeken of de gevonden relaties ook gelden voor hogere ds-gehalten van het strooisel. Daarnaast is het van belang om het inzicht in de afzonderlijke effecten van ds-gehalte van het strooisel en het ventilatiedebiet op stalniveau op de ammoniakemissie te vergroten. In praktijkstallen zijn deze twee altijd met elkaar verstrengeld. Om deze redenen werd in 2014/2015 nieuw experimenteel onderzoek uitgevoerd, eveneens bestaande uit twee ronden, met als uiteindelijke doel te komen tot een rekenmodel waarmee de ammoniakemissie kan worden berekend/geschat op basis van een aantal inputfactoren. In dit rapport worden de opzet en de resultaten van alle vier de ronden van het experimentele onderzoek integraal geanalyseerd en beschreven en de huidige stand van zaken van het rekenmodel toegelicht.

\subsection{Doelstelling}

De doelstelling van dit onderzoek is tweeledig:

1. Het vaststellen van het effect van het kalium- en ruw eiwitgehalte van het voer op de strooiselkwaliteit/-karakteristieken (ds-gehalte, $\mathrm{pH}$, strooiseltemperatuur, rulheid, totaal stikstof en ammonium stikstof gehaltes van het strooisel) en de ammoniakemissie.

2. Het ontwikkelen van een rekentool om het effect van voermaatregelen op de ammoniakemissie te kunnen voorspellen. 


\section{Materiaal en methoden}

\section{$2.1 \quad$ Algemeen}

Om verschillen te kunnen creëren in temperatuur $(T)$ en relatieve luchtvochtigheid (RV) in de stal, zodat het effect van het buitenklimaat op de strooiselkenmerken kon worden gesimuleerd, werd dit onderzoek uitgevoerd in twee klimaatcellen. Daarnaast werden, om verschillen in het ds-gehalte van de uitgescheiden mest te creëren, voeders met een verschillend K-gehalte gebruikt. In totaal besloeg het onderzoek vier ronden.

In de eerste ronde werd het effect van de relatieve luchtvochtigheid bestudeerd en het vochtgehalte van de uitgescheiden mest op de ammoniakemissie bestudeerd. Er werden hiertoe metingen uitgevoerd bij twee relatieve luchtvochtigheidsinstellingen (50 en 75\%) en vier K-gehalten van het $\operatorname{voer}(8,910$ en $11 \mathrm{~g} \mathrm{~K} / \mathrm{kg})$.

In de tweede ronde is het effect van het ventilatiedebiet en het vochtgehalte van de uitgescheiden mest onderzocht. Hiertoe werden ammoniakemissiemetingen uitgevoerd bij twee ventilatiedebieten ( 1 en $2 \mathrm{m3} / \mathrm{kg}$ lichaamsgewicht) en voeders met een verschillend K-gehalte (8, 910 en $11 \mathrm{~g} \mathrm{~K} / \mathrm{kg}$ ).

In de derde en vierde ronde werden ammoniakemissiemetingen uitgevoerd bij voeders die verschilden in ruw eiwit gehalte ( 2 niveaus; ronde 3: normaal en hoog en ronde 4: normaal en laag) en K-gehalte ( 2 niveaus: 7 en $9 \mathrm{~g} \mathrm{~K} / \mathrm{kg}$ ).

\section{$2.2 \quad$ Materiaal}

\subsubsection{Accommodatie}

Het onderzoek werd uitgevoerd in twee cellen van de klimaatstal 160 van WUR-CVI, Runderweg, Lelystad. In elke cel ( $35 \mathrm{~m} 2$ ) stonden acht grondhokken (oppervlakte: 1,5 m2) met strooisel (witte houtkrullen: $2 \mathrm{~kg} / \mathrm{m} 2$ ) opgesteld (zie Figuur 1). In deze klimaatcellen kan zowel de temperatuur als de relatieve luchtvochtigheid nauwkeurig worden gecontroleerd. De geconditioneerde lucht komt binnen via een gaatjesplafond en wordt afgevoerd via een ventilator in de achtergevel van de cel/ruimte. De cellen werden verlicht met 8 dimbare led lampen(Glow led bulb 7W 2700K Dimmable) per cel.

\subsubsection{Diermateriaal}

In alle ronden werden telkens 400 haankuikens van het type Ross 308 opgezet, 25 vleeskuikens per grondhok. De eerste drie ronden omvatte het leeftijdstraject van 0 - 35 dagen, terwijl de vierde ronde het leeftijdstraject van 0 - 42 dagen omvatte. Binnen een ronde werden kuikens gebruikt van dezelfde herkomst (moederdieren). De eendagskuikens werden geleverd door Probroed \& Sloot te Meppel.

Type: $\quad$ Ross 308 vleeskuikens (gallus gallus)

Geslacht: mannelijk (haantjes)

Leeftijd ouderdieren: Ronde 1: 54 weken; Ronde 2: 44 weken; Ronde 3: 37 weken; Ronde 4: 42 weken

Aantal/ronde: $\quad 400$

Leverancier: $\quad$ Probroed \& Sloot, Meppel, Nederland

De kuikens werden op de broederij gesekst en willekeurig verdeeld over de hokken. 


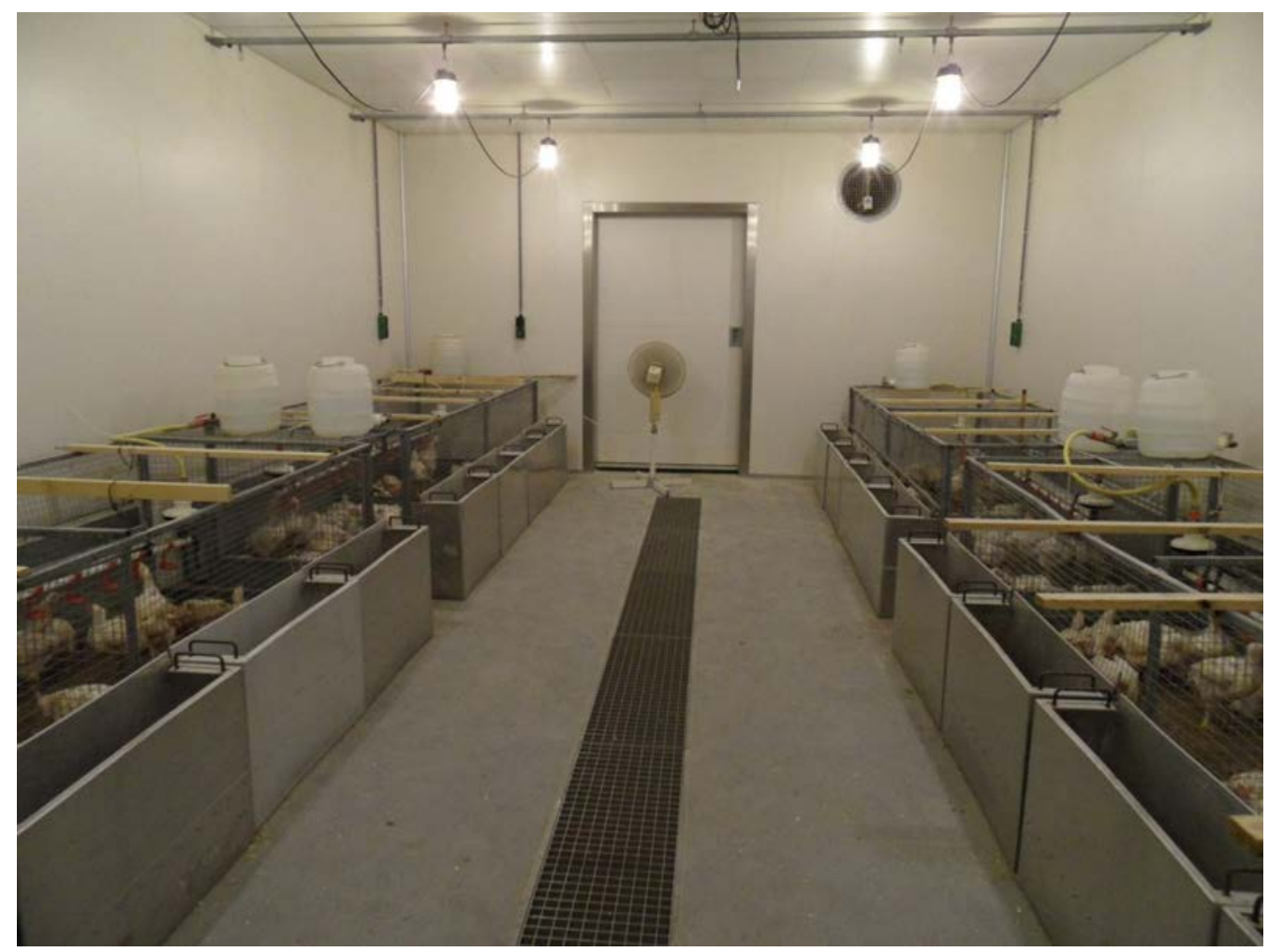

Figuur 1 De kuikens werden gehuisvest in twee klimaatcellen met elk 8 grondhokken (oppervlakte $1,5 \mathrm{~m}^{2}$ per hok).

\subsubsection{Proefbehandelingen}

\section{Ronde 1}

In de eerste ronde werden de volgende behandelingsfactoren onderzocht:

1. K-gehalte voer (4 instellingen: $8,9,10$ en $11 \mathrm{~g} / \mathrm{kg}$ )

2. Relatieve luchtvochtigheid (RV) stallucht ( 2 instellingen: 50 en $75 \%$ ) De ventilatie stond in beide klimaatcellen ingesteld op $1 \mathrm{~m}^{3} / \mathrm{kg}$ per uur.

Tabel 1 Schematische opzet van het onderzoek (ronde 1)

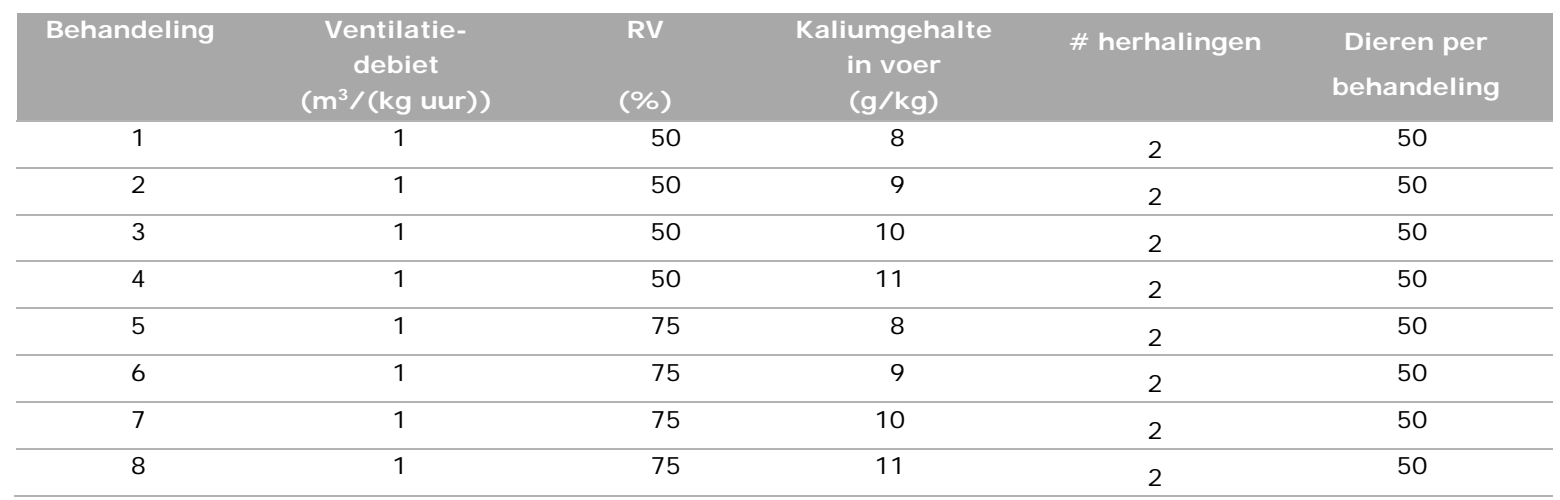

\section{Ronde 2}

In de tweede ronde werden de volgende behandelingsfactoren onderzocht:

1. K-gehalte voer (4 instellingen: $8,9,10$ en $11 \mathrm{~g} / \mathrm{kg}$ )

2. Ventilatie debiet ( 2 instellingen: 1 en $2 \mathrm{~m}^{3} / \mathrm{kg}$ per uur)

De relatieve luchtvochtigheid (RV) was in beide klimaatcellen ingesteld op $50 \%$. 
Tabel 2 Schematische opzet van het onderzoek (ronde 2)

\begin{tabular}{|c|c|c|c|c|c|}
\hline 2 & 1 & 50 & 9 & 2 & 50 \\
\hline 3 & 1 & 50 & 10 & 2 & 50 \\
\hline 5 & 2 & 50 & 8 & 2 & 50 \\
\hline 6 & 2 & 50 & 9 & 2 & 50 \\
\hline 7 & 2 & 50 & 10 & 2 & 50 \\
\hline 8 & 2 & 50 & 11 & 2 & 50 \\
\hline
\end{tabular}

$\underline{\text { Ronde } 3}$

In de derde ronde werden de volgende behandelingsfactoren onderzocht:

1. Ruw eiwitgehalte voer ( 2 instellingen: normaal/hoog)

2. K-gehalte voer ( 2 instellingen: 7,0 en $8,5 \mathrm{~g} \mathrm{~K} / \mathrm{kg}$ )

3. RV stallucht ( 2 instellingen: 50 en $60 \%$ )

De ventilatie stond in beide klimaatcellen ingesteld op $1 \mathrm{~m}^{3} / \mathrm{kg}$ per uur.

Tabel 3 Schematische opzet van het onderzoek (ronde 3)

\begin{tabular}{|c|c|c|c|c|c|c|}
\hline Behandeling & $\begin{array}{c}\text { Ventilatie- } \\
\text { debiet } \\
\text { ( } \mathrm{m}^{3} / \mathrm{kg} / \text { uur) }\end{array}$ & $\begin{array}{c}\text { RV } \\
(\%)\end{array}$ & $\begin{array}{c}\text { Kalium- } \\
\text { gehalte in } \\
\text { voer }(\mathbf{g} / \mathbf{k g})\end{array}$ & $\begin{array}{c}\text { Ruw eiwit } \\
\text { in voer }\end{array}$ & \# herhalingen & $\begin{array}{l}\text { Dieren per } \\
\text { behandeling }\end{array}$ \\
\hline 1 & 1 & 50 & 7,0 & Normaal & 2 & 50 \\
\hline 2 & 1 & 50 & 8,5 & Normaal & 2 & 50 \\
\hline 3 & 1 & 50 & 7,0 & Hoog & 2 & 50 \\
\hline 5 & 1 & 60 & 7,0 & Normaal & 2 & 50 \\
\hline 6 & 1 & 60 & 8,5 & Normaal & 2 & 50 \\
\hline 7 & 1 & 60 & 7,0 & Hoog & 2 & 50 \\
\hline 8 & 1 & 60 & 8,5 & Hoog & 2 & 50 \\
\hline
\end{tabular}

$\underline{\text { Ronde } 4}$

In de vierde ronde werden de volgende behandelingsfactoren onderzocht:

1. Ruw eiwitgehalte voer ( 2 instellingen: normaal/laag)

2. K-gehalte voer ( 2 instellingen: 7,0 en $9,0 \mathrm{~g} \mathrm{~K} / \mathrm{kg}$ )

De ventilatie stond in beide klimaatcellen ingesteld op $1,2 \mathrm{~m}^{3} / \mathrm{kg}$ per uur en de RV-instellingen waren voor beide klimaatcellen gelijk.

In alle ronden, met uitzondering van de vierde ronde, werd een tweefasen voedering toegepast. Gedurende de eerste 10 dagen ontvingen de kuikens een startvoer, en van dag 11 tot en met 35 dagen een groei-/afmestvoer. In de vierde ronde werd een 3-fasenvoeding toegepast; van 0 - 10 dagen ontvingen de kuikens startvoer, van 11 - 32 dagen een groeivoer en van 33 - 42 dagen werd een eindvoer verstrekt. In de vierde ronde was een marker (titaniumoxide) aan het voer toegevoegd om de (verse) mestproductie van de kuikens te kunnen bepalen. Dit is een standaard methode binnen Wageningen Livestock Research om de verse mestproductie te bepalen. Titaniumoxide wordt namelijk volledig uitgescheiden door het dier. Deze methode is ook beschreven in de volgende artikelen: (Short et al., 1996) en (Morgan et al., 2014).

Het voer werd geproduceerd en geleverd door Research Diet Services BV te Wijk bij Duurstede. Alle voeders werden gepelleteerd (startvoeders: $2,5 \mathrm{~mm}$ en groei- en eindvoeders: $3 \mathrm{~mm}$ ). De samenstelling en de berekende nutriëntengehalten van de voeders staan vermeld in bijlagen 1 (ronde 1 en 2 ), bijlage 2 (ronde 3 ) en bijlage 3 (ronde 4 ). 
Tabel 4 Schematische opzet van het onderzoek (ronde 4)

\begin{tabular}{ccccccc} 
Behandeling & $\begin{array}{c}\text { Ventilatie- } \\
\text { debiet } \\
\left(\mathrm{m}^{3} / \mathrm{kg} / \text { uur }\right)\end{array}$ & $\begin{array}{c}\text { RV } \\
(\%)\end{array}$ & $\begin{array}{c}\text { Kalliumgehalte } \\
\text { in voer } \\
(\mathrm{g} / \mathrm{kg})\end{array}$ & $\begin{array}{c}\text { Ruw eiwit } \\
\text { in voer }\end{array}$ & $\begin{array}{c}\text { Nieren per } \\
\text { herhalingen }\end{array}$ \\
\hline 1 & 1,2 & 50 & 7,0 & Normaal & 4 & 100 \\
\hline 2 & 1,2 & 50 & 9,0 & Normaal & 4 & 4 \\
\hline 3 & 1,2 & 50 & 7,0 & Laag & 4 \\
\hline 4 & 1,2 & 50 & 9,0 & Laag & 400 \\
\hline
\end{tabular}

Binnen een klimaatcel werden de voerbehandelingen willekeurig verloot over de grondhokken. Voer en water werden gedurende de gehele proefperiode ( 0 - 35 dagen) onbeperkt aangeboden aan de kuikens.

\subsubsection{Verlichting}

De vleeskuikens kregen de eerste 2 dagen continu licht (24L:0D). Daarna werd een dag/nachtschema gehanteerd van 18L:6D. De lichtsterkte bedroeg de gehele proefperiode 20 lux.

\subsubsection{Klimaat}

\section{Ronde 1}

De temperatuur bij opzet van de kuikens bedroeg $34^{\circ} \mathrm{C}$. De temperatuur werd geleidelijk afgebouwd naar $20^{\circ} \mathrm{C}$ op 28 dagen leeftijd. Deze temperatuur werd tot het einde van de proef aangehouden. In de ene klimaatcel werd een relatieve luchtvochtigheid (RV) aangehouden van $50 \%$, in de andere een RV van $75 \%$. De ventilatie was ingesteld op $1 \mathrm{~m}^{3}$ per kilogram lichaamsgewicht per uur.

\section{Ronde 2}

In de tweede ronde werd eenzelfde temperatuurschema als in de eerste ronde gehanteerd. In tegenstelling tot in de eerste ronde werd in de tweede ronde in beide klimaatcellen dezelfde RV aangehouden (50\%) en werd er een verschil in minimum ventilatiedebiet aangehouden (resp. 1 en 2 $\mathrm{m}^{3}$ /uur per kg lichaamsgewicht).

\section{Ronde 3 en 4}

In de derde en vierde ronde werd hetzelfde temperatuurschema gehanteerd als in ronde 2 . In ronde 4 hadden de vleeskuikens een leeftijdstraject van 0 - 42 dagen en in deze ronde werd de temperatuur vanaf dag 35 afgebouwd van $20^{\circ} \mathrm{C}$ naar $19^{\circ} \mathrm{C}$ op dag 42 . Het ventilatiedebiet was ingesteld op $1,0 \mathrm{~m}^{3}$ per kilogram lichaamsgewicht per uur.

In bijlage 4 worden de ingestelde temperatuur, relatieve luchtvochtigheden en ventilatiedebiet per dag en per ronde weergegeven. In bijlage 5 worden de gerealiseerde temperaturen, relatieve luchtvochtigheden en ventilatiedebieten vermeld.

\subsubsection{Entingen}

De kuikens zijn op de broederij gevaccineerd tegen Infectieuze Bronchitis (IB primer), waarna ze op 14 en 21 dagen werden gevaccineerd tegen respectievelijk Newcastle Disease (Clone 30) en Gumboro (D78).

\subsubsection{Strooisel}

Als strooiselmateriaal werden witte houtkrullen gebruikt ( $3 \mathrm{~kg} /$ grondkooi $=2 \mathrm{~kg} / \mathrm{m}^{2}$ ). 


\subsection{Methoden}

\subsubsection{Waarnemingen}

$\underline{\text { Voer }}$

Alle voeders werden geanalyseerd op: droge stof, ruw eiwit, ruw vet, ruwe celstof, as, calcium, fosfor en kalium. In de vierde ronde werd tevens de hoeveelheid marker (titaniumoxide) in het voer bepaald. De analyses zijn uitgevoerd door NutriControl, Postbus 107, 5460 AC Veghel.

\section{Ammoniakmetingen}

Op dag 20, 21, 27, 28, 34, 35 en in ronde 4 ook op dag 41 en 42 dagen werd via de zogenaamde dynamische boxmethode per hok de ammoniakemissie bepaald (Figuur 2). Bij dynamische boxmetingen wordt een doos over het emitterend strooiseloppervlak geplaatst. Bij de toepassing in deze cellen werd lucht vanuit de centrale gang van de klimaatstal over het emitterend oppervlak van de meetbox aangezogen door een ventilator en in de klimaatcel geblazen. De ammoniakconcentraties van de ingaande lucht en uitgaande lucht van de box werden gemeten m.b.v. multigas monitoren (Innova's van het type 1312). Daarnaast werd ter controle (halverwege elke meting) de ammoniakconcentratie tevens gemeten met Kitagawa gasdetectiebuisjes (type No. 105SD $0.2-20$ ppm). De gegevens van deze gasdetectiebuisjes zijn niet gebruikt in de analyses. Tevens werd het ventilatiedebiet gemeten. Het product van het ventilatiedebiet en de concentratie bij de uitlaat geeft de emissie weer vanaf de bemeten oppervlakte. De dynamische box meetmethode is primair ontwikkeld om emissieverschillen vast te stellen en niet om absolute stalemissies te bepalen zoals bedoeld in de Regeling ammoniak en veehouderij (Rav).
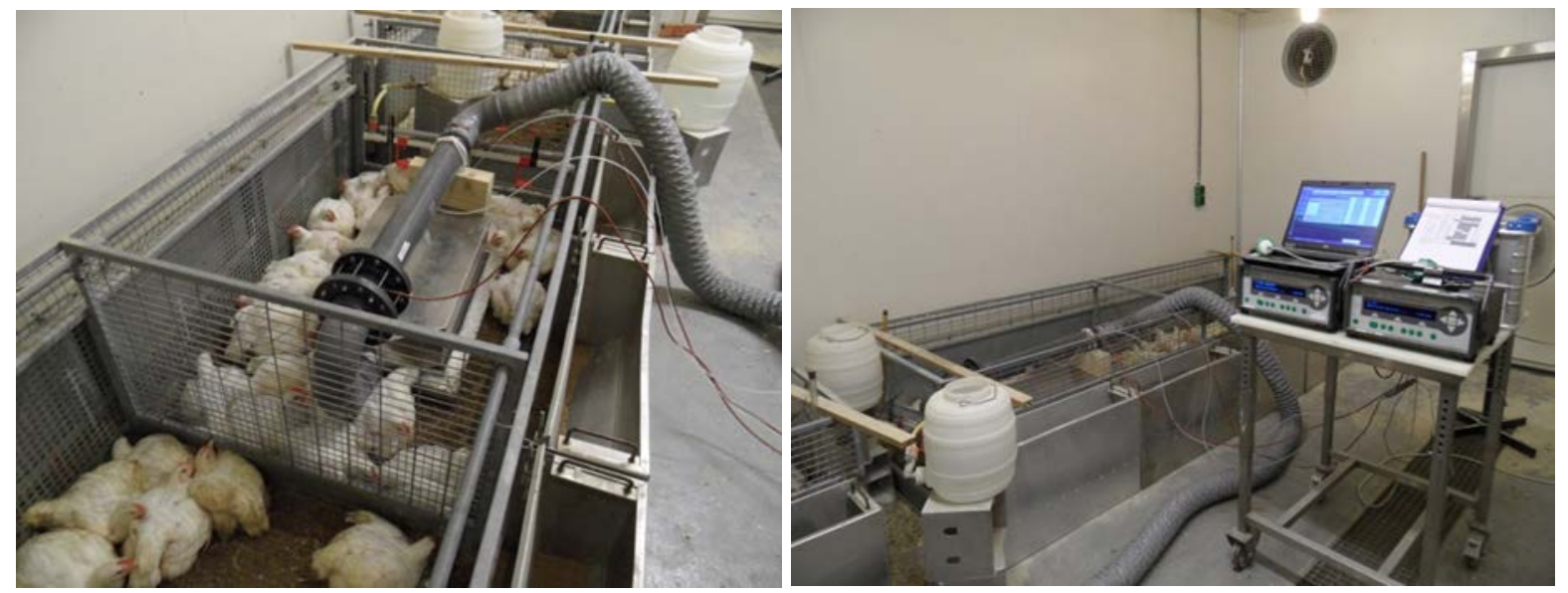

Figuur 2 Ammoniakemissie meting via de dynamische box meetmethode.

Ervan uitgaande dat gedurende de meting het ventilatiedebiet en de ammoniakvervluchtiging vanaf het gemeten oppervlak constant blijven, zal na enige tijd een evenwichtsconcentratie in de meetbox worden bereikt (stabilisatietijd). In de praktijk gebeurt dit na enkele minuten. Een verdere beschrijving van de meetmethodiek m.b.v. de dynamische meetbox (fluxkamer) is te vinden in Mosquera et al. (2010).

Voor dit onderzoek is een speciale kleinere meetbox ontwikkeld welke geschikt is voor het meten van gassen in kleine hokken. De maten van de box zijn $60 \times 40 \times 15 \mathrm{~cm}(\mathrm{l} \times \mathrm{b} \times \mathrm{h})$. Het oppervlak van de box is $0,24 \mathrm{~m}^{2}$ en de inhoud is $0,036 \mathrm{~m}^{3}$. De netto ammoniakemissie werd als volgt bepaald:

$Q=\frac{\left(D \cdot\left(C_{u i t}-C_{i n}\right)\right)}{A}$

Waarin: $Q$ is de ammoniakemissie $\left(\mathrm{mg} /\left(\right.\right.$ uur. $\left.\mathrm{m}^{2}\right)$ )

$D$ is het ventilatiedebiet ( $\mathrm{m}^{3} /$ uur)

$C_{\text {in }}$ is de ammoniakconcentratie van de ingaande lucht $\left(\mathrm{mg} / \mathrm{m}^{3}\right)$

cuit is de ammoniakconcentratie van de uitgaande lucht $\left(\mathrm{mg} / \mathrm{m}^{3}\right)$

A is het meetoppervlak (= oppervlakte meetbox) $\left(\mathrm{m}^{2}\right)$ 
Aan de ventilator in de uitgaande luchtstroom was een meetwaaier gekoppeld voor regeling van de ventilator en vastlegging van het debiet. De meetwaaier gaf een puls-signaal. Met een bekende factor is het aantal pulsen om te rekenen naar een aantal omwentelingen per minuut. Het puls-signaal werd iedere 2 minuten vastgelegd in een datalogger van het type Koenders CR10. Met de ijklijn van de ventilator (figuur Bijlage 6) en het vastgelegde puls-signaal $(P$, in $H z)$ is het debiet (D) in $\mathrm{m}^{3} / \mathrm{uur}$ berekend: $D=0,668 * P$.

In de eerste meetronde bedroeg het ventilatiedebiet (luchtstroom over het meetoppervlak) in de meetbox ca. $20 \mathrm{~m}^{3} /$ uur. In de overige drie meetronden werd gemeten bij twee debieten: ca. 20 en 40 $\mathrm{m}^{3} /$ uur. Bij deze debieten wordt de lucht met een gemiddelde snelheid van respectievelijk ca. 0,2 en $0,4 \mathrm{~m} / \mathrm{s}$ over het strooisel geleid. Op de eerste meetdag in een bepaalde week werden hokken 1 - 4 en hokken 13 - 16 bemeten bij de lage luchtsnelheid en de hokken 5 - 8 en hokken 9 - 12 bemeten bij de hoge luchtsnelheid ( 1 hok per behandeling bij lage luchtsnelheid en 1 hok per behandeling bij hoge luchtsnelheid). Op de tweede meetdag van de week was dit precies andersom.

Zoals eerder aangeven werd de ammoniakconcentratie van de in- en uitgaande lucht gemeten met twee Innova's van het type 1312. Dit zijn multigas monitoren met een foto-akoestisch meetprincipe. Deze meetmethode is gebaseerd op het effect van infrarood licht op gassen. Als een gas wordt blootgesteld aan infrarood licht met een golflengte die dat gas absorbeert zal een deel van het licht worden geabsorbeerd. Als gevolg hiervan krijgt een aantal moleculen een hoger energieniveau wat leidt tot een stijging van temperatuur en druk. Valt het infrarood licht weg dan zullen de moleculenweer terugvallen naar hun oorspronkelijke energieniveau en de temperatuur en druk zullen weer dalen.

Wanneer een gas pulserend wordt belicht ontstaat een steeds wisselende druk die resulteert in een geluidsgolf die met behulp van microfoons kan worden gedetecteerd. De concentratie van het gas in een monster wordt dan door de sterkte van het signaal bepaald. Elke monitor nam elke twee minuten een luchtmonster ter analyse. Ammoniakconcentraties zijn vastgelegd in ppm (parts per million) en later omgerekend naar $\mathrm{mg} / \mathrm{m}^{3}$ en wel als volgt: $\mathrm{NH}_{3}$-concentratie (in $\mathrm{mg} / \mathrm{m}^{3}$ ) $=\mathrm{NH}_{3}$-concentratie (in ppm) * 17/24. Hierin is 17 de molaire massa van ammoniak ( $\mathrm{g} / \mathrm{mol})$ en 24 het molaire volume van lucht $\left(\mathrm{dm}^{3} / \mathrm{mol}\right)$ bij $20^{\circ} \mathrm{C}$ en 1 bar. Het molaire volume van lucht is enigszins temperatuur afhankelijk, maar dit is vrijwel te verwaarlozen $\left(1,7 \%\right.$ verschil bij een verhoging of verlaging met $5^{\circ} \mathrm{C}$ ).

In bijlage 6 wordt de gehanteerde werkwijze tijdens de boxmetingen beschreven.

\section{Samenstelling verse feces}

In de derde en vierde ronde werden er per hok wekelijks verse mest/feces monsters genomen. Hiertoe werd gedurende 2 - 4 uur (tijd is afhankelijk van de hoeveelheid mest die geproduceerd wordt, omdat voor de analyses minimaal 30 gram materiaal nodig is) een teflon mestverzamelplaat in elk hok gelegd. Na deze 2 - 4 uur werd alle op deze plaat geproduceerde mest verwijderd, in een (gecodeerd) plasticzakje gedaan, waarna het monster direct werd ingevroren. In de verse mestmonsters werden de volgende analyses gedaan: droge stof, as, totaal stikstof, ammoniumstikstof en kalium. In de vierde ronde werd tevens het titaniumoxide gehalte bepaald, dit om de hoeveelheid geproduceerde verse mest te bepalen. De analyses werden verricht door het Servicelab van Wageningen Livestock Research.

Bepaling strooiselkarakteristieken

Op de meetlocaties werd direct na de emissiemeting m.b.v. een infrarood thermometer (Testo 830T4) de oppervlakte (infrarood) en inwendige strooiseltemperatuur (steekvoeler) gemeten. Daarnaast werd de rulheid van het strooisel visueel beoordeeld (zie tabel 5), door steeds dezelfde persoon, en werd op negen plaatsen een strooiselmonster genomen. Deze negen monsters werden gepoold tot één monster (ca. $200 \mathrm{~g}$ strooisel) per hok, waarna op het laboratorium de pH werd bepaald en de navolgende analyses werden verricht: droge stof, as, kalium, totaal stikstof en ammonium stikstof. Deze analyses werden verricht door het Servicelab van Wageningen Livestock Research. 
Tabel 5 Beoordelingscriteria rulheid strooisel

\begin{tabular}{cl} 
Waardering & Omschrijving \\
2 & Volledig dichtgeslagen strooisel, één grote plaat/koek \\
3 & $80-90 \%$ van het strooiseloppervlak is dichtgeslagen \\
4 & $70-80 \%$ van het strooiseloppervlak is dichtgeslagen \\
5 & $60-70 \%$ van het strooiseloppervlak is dichtgeslagen \\
6 & $50-60 \%$ van het strooiseloppervlak is dichtgeslagen \\
7 & $40 \%$ van het strooiseloppervlak is dichtgeslagen \\
8 & $30 \%$ van het strooiseloppervlak is dichtgeslagen \\
9 & $10 \%$ van het strooiseloppervlak is dichtgeslagen \\
10 & Volledig rul strooisel, beginnende plaatjes vorming \\
\hline
\end{tabular}

Gebruikte analysemethode(n):

WI 4.25-107 Monstervoorbehandeling door drogen na toevoeging van wijnsteenzuur. Stapelbare mest met een geschat ds-gehalte van tenminste $30 \%$

WI 4.25-109 Monstervoorbehandeling door malen. Dierlijke mest met een geschat ds-gehalte van tenminste $85 \%$

WI 4.25-103 Bepaling van het gehalte aan opgelost ammoniumstikstof in dierlijke mest. Destillatie methode

WI 4.25-104 Destructie van dierlijke mest t.b.v. NPK-analyses

WI 4.25-105 De bepaling van (totaal) stikstof in destruaten verkregen volgens WI 4.25-104.

Destillatie methode

WI 4.25-106 De bepaling van opgelost fosfaat in destruaten verkregen volgens WI 4.25-104.

Fotometrische methode

WI 4.25-111 Bepaling van het gehalte aan droge stof in dierlijke mest. Gravimetrische methode

WI 4.25-112 Bepaling van het gehalte aan organische stof in dierlijke mest. Gravimetrische methode

WI 4.25-113 Bepaling van de $\mathrm{pH}$. De $\mathrm{pH}$ is gemeten na verdunning van $1+4$ van het monster met demiwater

Voetzoollaesies en hakdermatitis

In de eerste drie ronden werd op 35 dagen leeftijd, steeds door dezelfde ervaren beoordelaar, bij alle nog aanwezige dieren in een hok visueel de incidentie en ernst van hakdermatitis (schaal 0, 1, 2, 3 en 4) en voetzoollaesies (schaal 0,1 en 2) vastgesteld. In de vierde ronde vond deze beoordeling plaats op 42 dagen leeftijd. In tabel 6 is een omschrijving van de scores voor hakdermatitis en voetzoollaesies gegeven. Op basis van de individuele scores per hok werd zowel voor hakdermatitis als voetzoollaesies een score berekend. De score voor hakdermatitis (HDS) is berekend als:

$H D S=\frac{((\text { aantal dieren score } 0 \text { of } 1 * 0)+(\text { aantal dieren score } 2 * 0,5)+(\text { aantal dieren score } 3 * 1)(\text { aantal dieren score } 4 * 2))}{n \text { totaal }} * 100$ (1)

waarbij ' $n$ totaal' het totaal aantal beoordeelde dieren is. De HDS kan dus variëren van 0 (alle dieren hebben een score 0 of 1 ) tot 200 (alle dieren hebben een score 4).

De score voor voetzoollaesies (VZL-score) werd als volgt berekend:

VZL-Score $=\frac{((\text { aantaldierenscore } 0 * 0)+(\text { aantaldierenscore } 1 * 0,5)+(\text { aantaldierenscore } 2 * 2))}{n \text { totaal }} * 100$

waarbij ' $n$ totaal' het totaal aantal beoordeelde dieren is. De VZL-score kan dus variëren van 0 (alle dieren hebben een score 0 ) tot 200 (alle dieren hebben een score 2). 


\begin{tabular}{|c|c|}
\hline Tabel 6 & $\begin{array}{l}\text { Beoordelingssystematiek voor de visuele beoordeling van de ernst van hakdermatitis en } \\
\text { voetzoollaesies. }\end{array}$ \\
\hline Parameter & Scoringsklassen + omschrijving \\
\hline Hakdermatitis & $\begin{array}{l}0-4 \text {, waarbij } 0=\text { geen hakirritatie, } 1=\text { lichte/geringe roodverkleuring hak; } 2= \\
\text { ernstige roodverkleuring / geringe aantasting opperhuid hak, geen wond zichtbaar } \\
\text { en } 3=\text { aantasting opperhuid hak, zwartverkleuring, klein oppervlak, } 4=\text { ernstige } \\
\text { aantasting opperhuid hak, zwartverkleuring, groot oppervlak, wond (Welfare } \\
\text { Quality, 2009). }\end{array}$ \\
\hline Voetzoollaesies & $\begin{array}{l}0-2 \text {, waarbij } 0=\text { geen/lichte voetzoolirritatie; } 1 \text { =matige/milde voetzoolirritatie } \\
\text { (hyperkeratose en verkleuring van het weefsel, maar nog geen ontstekingen en } \\
\text { nog geen aantasting van de opperhuid) en } 2=\text { ernstige voetzoolirritatie(aantasting } \\
\text { van de opperhuid, onderhuidse ontstekingen). Beoordelingsmethodiek conform } \\
\text { Zweedse methode (Berg, 1998). }\end{array}$ \\
\hline
\end{tabular}

\section{Productieresultaten}

De groei, het voer- en het waterverbruik werden per voerfase bepaald. In Ronde $1 \mathrm{t} / \mathrm{m} 3$ werd alleen op dag10 overgeschakeld van voer (startvoer naar groei-/afmestvoer) en in Ronde 4 op twee momenten, op dag 10 van start- naar groeivoer en op dag 32 naar eindvoer. Daarnaast werd dagelijks de uitval/selectie en gewicht van uitval/selectie genoteerd. Op deze wijze konden de productieresultaten (groei, voeropname, voerconversie, waterverbruik, water/voer verhouding en uitval) per voerfase en over de gehele productieperiode worden berekend. In deze rapportage worden de behaalde resultaten over de volledige productieronde beschreven. Tevens werd over de volledige productieperiode (ronde 1-3: 0 - 35 dagen en ronde 4: 0 - 42 dagen) het productiegetal berekend. Het productiegetal is een maatstaf voor de behaalde technische resultaten. Voor de berekening van het productiegetal is gebruikt gemaakt van de volgende productiegegevens:

o Dagelijkse groei

o Voerconversie

o Uitval

De formule voor het productiegetal is zo opgesteld dat (financieel) gunstige resultaten van deze parameters (groei, voerconversie en uitval) de waarde van het productiegetal doen stijgen. D.w.z. een hogere daggroei en/of een lagere voerconversie en/of een lagere uitval resulteren in een hoger productiegetal. Het productiegetal is als volgt berekend:

Productiegetal $=((100-$ uitvalspercentage $) \times$ daggroei in gram $) /($ voerconversie $x 10)$

\section{Klimaat}

De afdelingstemperaturen en RV werden continu geregistreerd via de centrale computer. Daarnaast werd de temperatuur en relatieve luchtvochtigheid van de ingaande en uitgaande lucht geregistreerd m.b.v. een ATAL ATV-11A datarecorder (T-range: $-30{ }^{\circ} \mathrm{C}-70^{\circ} \mathrm{C}$; RV-range: $0-100 \%$ ).

\subsubsection{Statistische analyse}

De gevonden productieresultaten, hakdermatitis- en voetzoollaesiescore van ronde 1 en 2 zijn geanalyseerd met behulp ANOVA gebruikmakend van het onderstaande statistische model.

$Y=\mu+$ ronde $/$ klimaatcel + kalium $+\varepsilon_{\text {error }}$

Waarin: $\quad \mathrm{Y}$ is de responsparameter (groei, voerconversie, uitval, voetzoollaesiescore, etc.);

$\mu$ is het algemeen gemiddelde;

ronde/klimaatcel is het ronde-effect en daarbinnen effect van klimaatcel;

kalium is het effect kaliumgehalte van het voer (4 factor-niveaus: $8,9,10$ of $11 \mathrm{~g} \mathrm{~K} / \mathrm{kg}$ )

$\varepsilon_{\text {error }}$ is de niet verklaarde restvariatie. 
De gevonden productieresultaten, hakdermatitis- en voetzoollaesiescore van ronde 3 en 4 zijn afzonderlijk geanalyseerd met behulp ANOVA gebruikmakend van het onderstaande statistische model.

$Y=\mu+$ ronde $/$ klimaatcel + kalium + eiwit + kalium.eiwit $+\varepsilon_{\text {error }}$

Waarin: $\quad \mathrm{Y}$ is de responsparameter (groei, voerconversie, uitval, voetzoollaesiescore, etc.);

$\mu$ is het algemeen gemiddelde

ronde/klimaatcel is het blokeffect van ronde en daarbinnen (blok)effect van klimaatcel;

kalium is het effect van kaliumgehalte van het voer ( 2 factor-niveaus: 7 en $9 \mathrm{~g} \mathrm{~K} / \mathrm{kg}$ );

eiwit is het effect van het ruw eiwitgehalte van het voer (ronde 3: 2 factor-niveaus, normaal en hoog; ronde 4:

2 factor-niveaus, normaal en laag);

kalium. eiwit is het interactie-effect tussen kalium en ruw eiwitgehalte voer;

$\varepsilon$ error is de niet verklaarde restvariatie.

Alle analyses zijn uitgevoerd met het statistische pakket Genstat ${ }^{\mathrm{TM}}$ Release 17.

Het effect van eiwit- en K-gehalte van het voer op de feces- en strooiselsamenstelling en de ammoniakemissie in alle vier ronden is bepaald door het gemiddelde van de gehalten aan eiwit en kalium in het voer over de gehele groeiperiode als continue variabelen op te nemen in het statistisch model:

$Y=$ constante + ronde + cel + ronde.cel + ronde.dagnr + eiwit + kalium + Eerror

Waarin: $\quad Y=$ te verklaren variabele

ronde, cel, ronde.cel = hoofdeffecten van ronde en cel en de interactie hiertussen

ronde.dagnr $=$ interactie- effect van ronde en dagnummer

eiwit $=$ het lineaire effect van eiwitgehalte van het voer $(\mathrm{g} / \mathrm{kg})$

kalium $=$ het lineaire effect van kaliumgehalte van het voer $(\mathrm{g} / \mathrm{kg})$

$\varepsilon_{\text {error }}=$ de restvariatie

Voorgaande analyse is uitgevoerd met de REML procedure van Genstat (Genstat Committee, 2014).

Met de REML procedure is tevens het effect van strooiselsamenstelling en het ventilatiedebiet in de meetbox op de ammoniakemissie geanalyseerd. Voor deze analyse is de ammoniakemissie eerst getransformeerd naar log-schaal. Het model zag er als volgt uit:

$L N(Y)=$ constante + ronde + cel + ronde.cel + ronde.dagnr + Ntot $+N H 4-N+p H+$ rulheid +

debiet $+\varepsilon_{\text {error }}$

Waarin: $\quad Y$ is de ammoniakemissie, op log-schaal geanalyseerd $\left(\mathrm{mg} /\left(\mathrm{m}^{2}\right.\right.$. uur $)$ )

ronde, cel, ronde.cel zijn de hoofdeffecten van ronde en cel en de interactie hiertussen

ronde.dagnr is het interactie-effect van ronde en dagnummer

Ntot is het lineaire effect van totaal stikstofgehalte van het strooisel $(\mathrm{g} / \mathrm{kg})$

$\mathrm{NH} 4-\mathrm{N}$ is het lineaire effect van het ammoniumstikstofgehalte van het strooisel $(\mathrm{g} / \mathrm{kg})$

$\mathrm{pH}$ is het lineaire effect van de zuurgraad van het strooisel (-)

rulheid is het lineaire effect van de rulheid van het strooisel (score van 1 - 10)

debiet is het ventilatiedebiet in de meetbox over het emitterend oppervlak $\left(\mathrm{m}^{3} / \mathrm{uur}\right)$ 


\section{Resultaten en discussie}

\section{$3.1 \quad$ Voer}

Tabel 7 Geanalyseerde ruw eiwit- en kaliumgehalten van de verschillende voeders in ronde 1 en 2. Tussen () staat de beoogde waarde vermeld

\begin{tabular}{llrrrr} 
No. & Voerbehandeling & Ruw eiwitgehalte $(\mathrm{g} / \mathrm{kg})$ & \multicolumn{1}{c}{ Kaliumgehalte $(\mathrm{g} / \mathrm{kg})$} \\
\hline 1 & & $0-10 \mathrm{dgn}$. & $11-35 \mathrm{dgn}$. & \multicolumn{1}{c}{0 -10 dgn. } & \multicolumn{1}{c}{$11-35$ dgn. } \\
\hline 2 & Normaal ruw eiwit, $8 \mathrm{~g} / \mathrm{kg}$ kalium & $218(220)$ & $208(205)$ & $8,8(8,0)$ & $8,7(8,0)$ \\
\hline 3 & Normaal ruw eiwit, $9 \mathrm{~g} / \mathrm{kg}$ kalium & $216(220)$ & $206(205)$ & $10,0(9,0)$ & $9,2(9,0)$ \\
\hline 4 & Normaal ruw eiwit, $10 \mathrm{~g} / \mathrm{kg}$ kalium & $224(220)$ & $209(205)$ & $10,8(10,0)$ & $10,5(10,0)$ \\
\hline
\end{tabular}

Uit tabel 7 blijkt dat de geanalyseerde ruw eiwitgehalten van zowel de start- als de groeivoeders goed overeenkomen met de beoogde waarden (range verschil: -4 tot $+4 \mathrm{~g} / \mathrm{kg}$ ). Uit tabel 7 blijkt verder dat de geanalyseerde K-gehalten van zowel de start- ( 0 - 10 dgn.) als de groei-/eindvoeders (11 - 35 dgn.) hoger zijn dan beoogd (range verschil: $+0,2$ tot $+1,0 \mathrm{~g} / \mathrm{kg}$ ). De verschillen tussen de beoogde en geanalyseerde K-gehalten zijn waarschijnlijk veroorzaakt door een hoger K-gehalte van de gebruikte sojaschroot t.o.v. het CVB tabellenboek. Geen van de gebruikte grondstoffen waren vooraf geanalyseerd.

In het vervolg van dit rapport zal voor de verschillende kaliumbehandelingen steeds de beoogde (berekende) K-gehalten worden aangegeven.

Tabel 8 Geanalyseerde ruw eiwit- en kaliumgehalten van de verschillende voeders in ronde 3. Tussen () staat de beoogde waarde vermeld

\begin{tabular}{llrrrr} 
No. & Voerbehandeling & Ruw eiwitgehalte $(\mathrm{g} / \mathrm{kg})$ & \multicolumn{2}{c}{ Kaliumgehalte $(\mathrm{g} / \mathrm{kg})$} \\
\hline & & $0-10 \mathrm{dgn}$. & $11-35 \mathrm{dgn}$. & $0-10 \mathrm{dgn}$. & $11-35 \mathrm{dgn}$. \\
\hline 1 & Hoog ruw eiwit, laag kalium & $236(235)$ & $200(205)$ & $7,3(7,0)$ & $7,7(7,0)$ \\
\hline 2 & Hoog ruw eiwit, normaal kalium & $238(235)$ & $206(205)$ & $9,0(8,5)$ & $9,2(8,5)$ \\
\hline 3 & Normaal ruw eiwit, laag kalium & $222(220)$ & $195(200)$ & $7,4(7,0)$ & $7,1(7,0)$ \\
\hline 4 & Normaal ruw eiwit, normaal kalium & $222(220)$ & $198(200)$ & $8,8(8,5)$ & $8,7(8,5)$ \\
\hline
\end{tabular}

In tabellen 8 en 9 worden de geanalyseerde en beoogde ruw eiwit- en K-gehalten vermeld van respectievelijk de derde en vierde ronde. Hieruit blijkt dat de geanalyseerde eiwit- en K-gehalten van de verschillende voeders goed overeenkomen met de beoogde gehalten (range verschil eiwitgehalte: 5 tot $+3 \mathrm{~g} / \mathrm{kg}$ in ronde 3 en -3 tot 0 in ronde 4 ; range verschil $\mathrm{K}$-gehalte: $+0,1$ tot $+0,7 \mathrm{~g} / \mathrm{kg}$ in ronde 3 en $-0,4$ tot $+0,1$ in ronde 4 ).

In het vervolg van dit rapport zal voor de verschillende kaliumbehandelingen steeds de beoogde Kgehalten worden aangegeven. Het ruw eiwitgehalte zal worden aangeduid met het niveau (normaal, hoog, laag). 
Tabel 9 Geanalyseerde ruw eiwit- en kaliumgehalten van de verschillende voeders in ronde 4.

Tussen () staat de beoogde waarde vermeld

\begin{tabular}{|c|c|c|c|c|c|c|c|}
\hline & \multirow[t]{2}{*}{ Voerbehandeling } & \multicolumn{3}{|c|}{ Ruw eiwitgehalte ( g/ kg) } & \multicolumn{3}{|c|}{ Kaliumgehalte ( $\mathrm{g} / \mathrm{kg}$ ) } \\
\hline & & $\begin{array}{l}0-10 \\
\text { dgn. }\end{array}$ & $\begin{array}{l}11-32 \\
\text { dgn. }\end{array}$ & $\begin{array}{l}\text { 33-42 } \\
\text { dgn. }\end{array}$ & $\begin{array}{l}0-10 \\
\text { dgn. }\end{array}$ & $\begin{array}{l}11-32 \\
\text { dgn. }\end{array}$ & $\begin{array}{l}33-42 \\
\text { dgn. }\end{array}$ \\
\hline 1 & Normaal ruw eiwit, laag kalium & $\begin{array}{l}219 \\
(220)\end{array}$ & $\begin{array}{l}202 \\
(205)\end{array}$ & $\begin{array}{l}182 \\
(185)\end{array}$ & $\begin{array}{l}7,1 \\
(7,0)\end{array}$ & $\begin{array}{l}6,9 \\
(7,0)\end{array}$ & $\begin{array}{l}6,8 \\
(7,0)\end{array}$ \\
\hline 2 & Normaal ruw eiwit, normaal kalium & $\begin{array}{l}218 \\
(220)\end{array}$ & $\begin{array}{l}204 \\
(205)\end{array}$ & $\begin{array}{l}183 \\
(185)\end{array}$ & $\begin{array}{l}8,9 \\
(9,0)\end{array}$ & $\begin{array}{l}9,0 \\
(9,0)\end{array}$ & $\begin{array}{l}8,6 \\
(9,0)\end{array}$ \\
\hline 3 & Laag ruw eiwit, laag kalium & $\begin{array}{l}197 \\
(200)\end{array}$ & $\begin{array}{l}184 \\
(185)\end{array}$ & $\begin{array}{l}164 \\
(165)\end{array}$ & $\begin{array}{l}6,8 \\
(7,0)\end{array}$ & $\begin{array}{l}7,1 \\
(7,0)\end{array}$ & $\begin{array}{l}6,7 \\
(7,0)\end{array}$ \\
\hline 4 & Laag ruw eiwit, normaal kalium & $\begin{array}{l}200 \\
(200)\end{array}$ & $\begin{array}{l}184 \\
(185)\end{array}$ & $\begin{array}{l}162 \\
(165)\end{array}$ & $\begin{array}{l}8,9 \\
(9,0)\end{array}$ & $\begin{array}{l}8,8 \\
(9,0)\end{array}$ & $\begin{array}{l}8,6 \\
(9,0)\end{array}$ \\
\hline
\end{tabular}

\subsection{Productieresultaten en welzijn}

In deze paragraaf worden de effecten van het eiwit- en K-gehalte van het voer op de productieresultaten (eindgewicht, groei, uitval, voerconversie, voerverbruik, waterverbruik en water/voerverhouding), de hakdermatitisscore en voetzoollaesiesscore beschreven. Zowel in ronde 3 als 4 bleek dat er op geen van de responskenmerken een interactie effect aanwezig was tussen het kalium- en het ruw eiwitgehalte van het voer. Om deze reden worden de resultaten per hoofdeffect (kalium- of ruw eiwitgehalte) beschreven. In Bijlage 7 zijn de productieresultaten voor elke behandelingscombinatie gegeven.

\subsubsection{Effect kaliumgehalte}

De kuikens die de voeders ontvingen met de hoogste twee K-gehalten groeiden significant minder snel, waardoor deze op 35 dagen leeftijd een duidelijk lager eindgewicht hadden dan de kuikens die de voeders met de laagste twee K-gehalten kregen (Tabel 10). Het K-gehalte in het voer had geen effect op het uitvalspercentage. De voerconversie verslechterde bij een $\mathrm{K}$-gehalte van $10 \mathrm{~g} / \mathrm{kg}$ en hoger. De voeropname laat dezelfde tendens zien als de groei, lagere voeropnames bij hogere K-gehalten. Het waterverbruik werd niet significant beïnvloed door het $\mathrm{K}$-gehalte van het voer. Aangezien het waterverbruik niet verschilde en de voeropname afnam bij een toenemend K-gehalte van het voer nam de water/voer verhouding significant toe bij een hoger K-gehalte van het voer. Het productiegetal, een maat voor het behaalde technische resultaat, werd significant beïnvloed door het K-gehalte. Het laagste productiegetal werd gevonden bij de groep met het hoogste K-gehalte (11 $\mathrm{g} / \mathrm{kg}$ ), gevolgd door de groep met $10 \mathrm{~g} \mathrm{~K}$ per $\mathrm{kg}$. Terwijl de groepen met het laagste K-gehalte in het voer het hoogste productiegetal hadden.

De kuikens die het voer kregen met het laagste $\mathrm{K}$-gehalte hadden de laagste voetzoollaesiescore. Er waren geen significante verschillen in de voetzoollaesiescore van de kuikens die de voeders met 9, 10 of $11 \mathrm{~g}$ kalium per kilogram ontvingen. De hakdermatitisscore lijkt toe te nemen bij het toenemen van het $\mathrm{K}$-gehalte in het voer. De hakdermatitisscore van de groep die het voer kregen met het laagste Kgehalte was significant lager dan die van de groepen die het voer kregen met de hoogste twee kaliumniveaus. Het verschil in hakdermatitisscore tussen de beide groepen met de laagste K-gehalten was niet significant. 


\begin{tabular}{|c|c|c|c|c|}
\hline $\begin{array}{l}\text { Het effect van } \\
\text { (ronde } 1 \text { en } 2 \text { ) }\end{array}$ & e op de $p$ & resultate & leeskuike & 35 dagen \\
\hline \multirow[t]{2}{*}{ Kenmerk } & \multicolumn{4}{|c|}{ Kaliumgehalte voer ( $\mathbf{g} / \mathbf{k g})$} \\
\hline & 8 & 9 & 10 & 11 \\
\hline Eindgewicht $(\mathrm{g})$ & $2219^{a}$ & $2185^{a}$ & $2001^{b}$ & $1872^{b}$ \\
\hline Groei $(\mathrm{g})$ & $2174^{\mathrm{a}}$ & $2139^{a}$ & $1955^{b}$ & $1826^{b}$ \\
\hline Uitval (\%) & 4,0 & 5,6 & 5,6 & 5,6 \\
\hline Voerconversie (g/g) & $1,521^{b}$ & $1,511^{b}$ & $1,595^{\text {a }}$ & $1,608^{a}$ \\
\hline Voerverbruik (g) & $3297^{a}$ & $3211^{a b}$ & $3099^{b}$ & $2931^{c}$ \\
\hline Water/voer verhouding $(\mathrm{kg} / \mathrm{kg})$ & $1,89^{c}$ & $1,97^{\mathrm{c}}$ & $2,07^{b}$ & $2,19^{\mathrm{a}}$ \\
\hline Waterverbruik (ml) & 6214 & 6302 & 6381 & 6396 \\
\hline Productiegetal (-) & $392^{a}$ & $382^{a}$ & $331^{b}$ & $306^{c}$ \\
\hline Voetzoollaesiescore (-) & $156^{b}$ & 173 ab & $197^{\text {a }}$ & $198^{\mathrm{a}}$ \\
\hline Hakdermatitisscore (-) & $117^{c}$ & $143^{b c}$ & $165^{a b}$ & $188^{a}$ \\
\hline
\end{tabular}

Verschillende letters in superscript geven significante verschillen aan $(P \leq 0,05)$

Tabel 11 Het effect van kaliumgehalte op de productieresultaten van vleeskuikens 0 - 35 dagen (ronde 3)

\begin{tabular}{|c|c|c|}
\hline Kenmerk & \multicolumn{2}{|c|}{ Kaliumgehalte ( $\mathrm{g} / \mathrm{kg}$ ) } \\
\hline Eindgewicht (g) & $2437^{a}$ & $2317^{b}$ \\
\hline Groei (g) & $2394^{a}$ & $2274^{b}$ \\
\hline Voerconversie (g/g) & 1,398 & 1,401 \\
\hline Voerverbruik (g) & $3348^{a}$ & $3186^{b}$ \\
\hline Water/voer $(\mathrm{kg} / \mathrm{kg})$ & $1,67^{b}$ & $1,82^{a}$ \\
\hline Hakdermatitisscore (-) & $5^{\text {(b) }}$ & $22^{(a)}$ \\
\hline
\end{tabular}

Verschillende letters geven significante verschillen aan $(P \leq 0,05)$; Verschillende letters tussen () geven een tendens weer $(0,10<P \leq 0,05)$

Kuikens die het lage K-gehalte in het voer ontvingen hadden een hogere groei en dus eindgewicht op 35 dagen leeftijd in vergelijking met de kuikens die het hoge K-gehalte in het voer ontvingen (Tabel 11). Uit Tabel 11 blijkt verder dat de kuikens met het lage K-gehalte in het voer een lagere uitval, een hoger voerverbruik, een lagere water/voerverhouding en een hoger productiegetal hadden in vergelijking met de kuikens met het hoge K-gehalte in het voer. De kuikens met het lage K-gehalte in het voer hadden een lagere voetzoollaesiescore en tevens was er een tendens naar een lagere hakdermatitisscore. Opvallend zijn de lage scores voor voetzoollaesies en hakdermatitis in ronde 3 ten opzichte van ronden 1 en 2 , maar ook ten opzichte van ronde 4 (zie Tabel 12). De belangrijkste oorzaak ligt waarschijnlijk bij de verschillen in gemeten rulheid van het strooisel. In ronde 3 werd het meest rulle strooisel gemeten (zie resultaten paragraaf 3.3). 


\begin{tabular}{|c|c|c|}
\hline $\begin{array}{l}\text { Het e } \\
\text { (rond }\end{array}$ & en van vle & lagen \\
\hline \multirow[t]{2}{*}{ Kenmerk } & \multicolumn{2}{|c|}{ Kaliumgehalte ( $\mathbf{g} / \mathbf{~ k g})$} \\
\hline & 7 & 9 \\
\hline Begingewicht (g) & 44 & 45 \\
\hline Eindgewicht $(\mathrm{g})$ & $3132^{a}$ & $2959^{b}$ \\
\hline Groei (g) & $3088^{a}$ & $2914^{b}$ \\
\hline Uitval (\%) & 4,7 & 3,6 \\
\hline Voerconversie $(\mathrm{g} / \mathrm{g})$ & 1,571 & 1,610 \\
\hline Voerverbruik (g) & $4851^{\text {(a) }}$ & $4688^{(b)}$ \\
\hline Water/voer & $1,63^{b}$ & $1,71^{a}$ \\
\hline Waterverbruik (ml) & 7915 & 8005 \\
\hline Productiegetal & $446^{a}$ & $415^{b}$ \\
\hline Hakdermatitisscore & $72 \mathrm{~b}$ & $130 a$ \\
\hline
\end{tabular}

Verschillende letters geven significante verschillen aan $(P \leq 0,05)$

Verschillende letters tussen () geven een tendens weer $(0,10<P \leq 0,05)$

In ronde 4 zien we vergelijkbare effecten van het $\mathrm{K}$-gehalte in het voer op de productieresultaten als in ronde 3 , met dit verschil dat het $\mathrm{K}$-gehalte in deze ronde geen significant effect had op de uitval (Tabel 12). Kuikens die het lage K-gehalte in het voer ontvingen hadden een hoger eindgewicht, een hogere groei, een lagere water/voer verhouding en een hoger productiegetal in vergelijking met de kuikens die het hoge $\mathrm{K}$-gehalte in het voer ontvingen $(P \leq 0,05)$. De kuikens met het lage $K$-gehalte in het voer hadden ook in deze ronde minder voetzoollaesies en hakdermatitis $(P \leq 0,05)$.

Enting (2009) geeft aan dat een verhoogd K-gehalte in het voer leidt tot een verhoogde water/voer verhouding en een vermindering van de strooiselkwaliteit. Dit komt overeen met de in dit onderzoek gevonden resultaten. De slechte strooiselkwaliteit, vooral bij de kuikens die voeders ontvingen met de hogere K-gehalten, was hoogstwaarschijnlijk ook de oorzaak van de slechtere productieresultaten (lager productiegetal, m.n. de lagere groei en slechtere voerconversie) bij deze groepen. Van Harn en de Jong (2013) vonden in hun studie, waarbij het strooisel stelselmatig nat werd gemaakt ook duidelijk verminderde productieresultaten (lagere groei, lager voer- en waterverbruik, slechtere voerconversie en lager productiegetal). Naast sterk verminderde productieresultaten vonden zij ook meer huidaandoeningen (meer borstirritaties, meer hakdermatitis en meer voetzoollaesies) en een verminderde locomotie bij de kuikens op het natte strooisel. Deze auteurs wijten de verminderde productieresultaten aan de verminderde locomotie als gevolg van de ernst van voetzoollaesies. Bij ernstige voetzoollaesies wordt lopen pijnlijk. Het kuiken zal daarom minder vaak naar het voer en water lopen, met als gevolg verminderde productieresultaten.

Samenvattend effect K-gehalte voer

In zijn algemeenheid kan worden geconcludeerd dat, binnen de onderzochte bandbreedte van het Kgehalte, de groei afneemt en de voerconversie en de water/voer verhouding toenemen bij een toenemend K-gehalte van het voer. Het K-gehalte lijkt geen effect te hebben op het uitvalspercentage. In hoeverre de afnemende groei een direct gevolg is van het hogere K-gehalte in het voer valt niet te zeggen. Het is goed mogelijk dat het $\mathrm{K}$-gehalte een indirect effect heeft via de strooiselkwaliteit, namelijk dat de verminderde groei wordt veroorzaakt door de slechtere strooiselkwaliteit en dien ten gevolge ernstiger problemen met voetzoollaesies waardoor het lopen van de kuikens pijnlijker wordt en de kuikens minder vaak naar het voer en water gaan. Een bijkomend effect van de slechtere strooiselkwaliteit is de verminderde mate van comfort a.g.v. een nat (en koud) ligbed. Kuikens worden smerig en nat en in (grote) stallen zie je een slechte verdeling van de kuiken in de stal (de natte plakken worden vermeden). 


\subsubsection{Effect eiwitgehalte}

In de derde en vierde ronde is naast het effect van het $\mathrm{K}$-gehalte van het voer, het effect van het eiwitgehalte van het voer onderzocht. Het blijkt dat het effect van het eiwitgehalte op de productieresultaten van vleeskuikens beperkt is. Het verstrekken van voeders met een iets hoger eiwitgehalte maar eenzelfde aminozurenpatroon dan gebruikelijk (ronde 3) had geen aantoonbaar effect op de groei, voerconversie en uitval, het resulteerde alleen in een significant hoger waterverbruik en een hogere water/voerverhouding. De hogere wateropname en dito water/voer verhouding resulteerde in een verminderde (natter en minder rul) strooiselkwaliteit. De slechtere strooiselkwaliteit bij kuikens die het voerprogramma kregen met het verhoogde eiwitgehalte resulteerde in een significant hogere hakdermatitis- en voetzoollaesiescore.

\begin{tabular}{|c|c|c|c|}
\hline Tabel 13 & \multicolumn{3}{|c|}{$\begin{array}{l}\text { Het effect van eiwitgehalte (re) op de productieresultaten van vleeskuikens } 0 \text { - } 35 \\
\text { dagen (ronde } 3 \text { ) }\end{array}$} \\
\hline \multicolumn{2}{|l|}{ Kenmerk } & normaal re & hoog re \\
\hline \multicolumn{2}{|c|}{ Begingewicht $(\mathrm{g})$} & 42 & 43 \\
\hline \multicolumn{2}{|c|}{ Eindgewicht (g) } & 2334 & 2420 \\
\hline \multicolumn{2}{|l|}{ Groei $(\mathrm{g})$} & 2292 & 2377 \\
\hline \multicolumn{2}{|l|}{ Uitval (\%) } & 3,5 & 6,5 \\
\hline \multicolumn{2}{|c|}{ Voerconversie (g/g) } & 1,401 & 1,399 \\
\hline \multicolumn{2}{|c|}{ Voerverbruik (g) } & 3211 & 3323 \\
\hline \multicolumn{2}{|c|}{ Water/voer (kg/kg) } & $1,67^{b}$ & $1,82^{a}$ \\
\hline \multicolumn{2}{|c|}{ Waterverbruik (ml) } & $5370^{b}$ & $6047^{a}$ \\
\hline \multicolumn{2}{|c|}{ Productiegetal (-) } & 451 & 454 \\
\hline \multicolumn{2}{|c|}{ Voetzoollaesiescore (-) } & $15^{\mathrm{b}}$ & $46^{a}$ \\
\hline \multicolumn{2}{|c|}{ Hakdermatitisscore (-) } & $4^{b}$ & $23^{a}$ \\
\hline
\end{tabular}

Verschillende letters geven significante verschillen aan $(P \leq 0,05)$

In de vierde ronde werd het effect van het verlagen van het eiwitgehalte op de productieresultaten onderzocht. Het bleek dat het verstrekken van een voerprogramma met een verlaagd eiwitgehalte, maar met eenzelfde aminozurenpatroon, geen aantoonbaar effect had op de groei, de uitval, het waterverbruik en water/voer verhouding. Wel is de voerconversie slechter bij het voerprogramma met het verlaagde eiwitgehalte. Het verlagen van het eiwitgehalte leidde niet tot minder voetzoollaesies en hakdermatitis.

Tabel 14 Het effect van eiwitgehalte (re) op de productieresultaten van vleeskuikens 0 - 42 dagen (ronde 4)

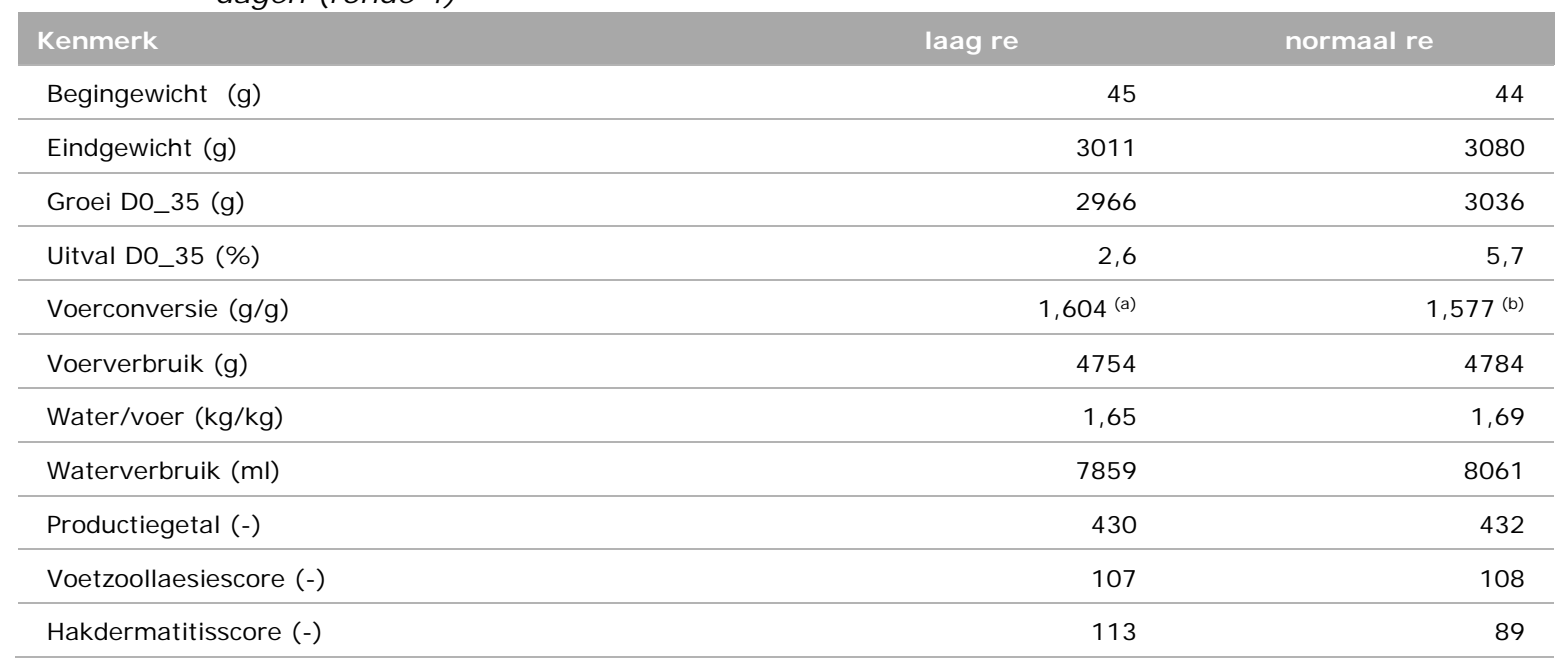

Verschillende letters tussen () geven een tendens weer $(0,10<\mathrm{P} \leq 0,05)$

Het verstekken van voeders met een verlaagd eiwitgehalte, al of niet aangevuld met vrije (essentiële) aminozuren, resulteerde in verschillende studies in slechtere productieresultaten, met name groei en 
voerconversie werden negatief beïnvloed (Dozier et al., 2008; Elwinger \& Svensson, 1996; Gates et al., 2000; Van Harn \& Van Middelkoop, 1996). Er zijn echter ook studies bekend waarbij geen verslechtering van de productieresultaten werd gevonden (o.a. (Holsheimer et al., 1993) en (Namroud et al., 2008)). Daarnaast vonden een aantal onderzoekers een lagere wateropname en een betere strooiselkwaliteit bij laag eiwitvoeders. Dit resulteerde weer in minder huidirritaties zoals hakdermatitis en voetzoollaesies (Nagaraj et al., 2007; Van Harn \& de Jong, 2012).

\section{Samenvattend effect eiwitgehalte voer}

- Het verstrekken van een voerprogramma met een verhoogd eiwitgehalte, maar met eenzelfde aminozurenpatroon, leidde tot een verhoogde wateropname en water/voer verhouding, de overige productieresultaten werden niet beïnvloed. Het resulteerde wel in een toename van het aantal en de ernst van hakdermatitis en voetzoollaesies.

- Het verstrekken van een voerprogramma met een verlaagd eiwitgehalte, maar met eenzelfde aminozurenpatroon, had geen aantoonbaar effect op de productieresultaten. Wel verslechterde de voerconversie enigszins. Het verstrekken van een laag eiwitvoer had geen effect op de ernst en voorkomen van voetzoollaesies en hakdermatitis.

\subsection{Feces- en strooiselsamenstelling}

In tabel 15 wordt de gemiddelde rulheid van het strooisel, de hoeveelheid strooisel(mest) aan het eind, de feces- en strooiselsamenstelling en de ammoniakemissie gegeven voor de verschillende experimentele ronden. 
Tabel 15 Gemiddelde feces- en strooiselsamenstelling, de strooiselhoeveelheid en de ammoniakemissie voor de verschillende ronden in het onderzoek. Tussen haakjes zijn de standaard deviaties weergegeven

\begin{tabular}{|c|c|c|c|c|c|}
\hline \multirow[t]{2}{*}{ Kenmerk } & \multicolumn{5}{|c|}{ Ronde } \\
\hline & 1 & 2 & 3 & $4(5 w)^{a)}$ & $4(6 w)^{a)}$ \\
\hline \multicolumn{6}{|l|}{ Feces-samenstelling } \\
\hline \multirow[t]{2}{*}{ Ds-gehalte uitgescheiden mest $(\mathrm{g} / \mathrm{kg})$} & - & - & 264 & 287 & 289 \\
\hline & & & $(46,2)$ & $(33,0)$ & $(34,5)$ \\
\hline \multirow[t]{2}{*}{ As-gehalte uitgescheiden mest $(\mathrm{g} / \mathrm{kg})$} & - & - & 37,4 & 41,3 & 41,4 \\
\hline & & & $(8,58)$ & $(5,92)$ & $(5,77)$ \\
\hline \multirow[t]{2}{*}{ Ntot-gehalte uitgescheiden mest $(\mathrm{g} / \mathrm{kg})$} & - & - & 14,5 & 12,2 & 12,5 \\
\hline & & & $(2,57)$ & $(2,48)$ & $(2,58)$ \\
\hline \multirow[t]{2}{*}{$\mathrm{NH} 4-\mathrm{N}$-gehalte uitgescheiden mest $(\mathrm{g} / \mathrm{kg})$} & - & - & 0,870 & 0,772 & 0,806 \\
\hline & & & $(0,428)$ & $(0,261)$ & $(0,276)$ \\
\hline \multirow[t]{2}{*}{$\mathrm{K}$-gehalte uitgescheiden mest $(\mathrm{g} / \mathrm{kg})$} & - & - & 8,09 & 6,86 & 7,02 \\
\hline & & & $(2,26)$ & $(1,53)$ & $(1,52)$ \\
\hline \multicolumn{6}{|l|}{ Stooiselkarakteristieken en -samenstelling } \\
\hline \multirow[t]{2}{*}{ Rulheid strooisel (score $0-10$ ) } & 2,58 & 3,92 & 6,29 & 5,15 & 4,30 \\
\hline & $(2,60)$ & $(2,37)$ & $(2,97)$ & $(3,31)$ & $(3,37)$ \\
\hline \multirow{2}{*}{$\begin{array}{l}\text { Hoeveelheid strooisel(mest) eind groeiperiode } \\
(\mathrm{kg} / \mathrm{hok})\end{array}$} & 42,6 & 46,8 & 25,0 & - & 44,0 \\
\hline & $(2,42)$ & $(3,98)$ & $(4,76)$ & & $(6,18)$ \\
\hline \multirow[t]{2}{*}{$\mathrm{pH}$ strooisel (-) } & 8,33 & 6,17 & 7,12 & 7,16 & 6,84 \\
\hline & $(0,41)$ & $(0,77)$ & $(0,55)$ & $(0,59)$ & $(0,86)$ \\
\hline \multirow[t]{2}{*}{ Ds-gehalte strooisel ( $\mathrm{g} / \mathrm{kg}$ ) } & 347 & 319 & 526 & 551 & 514 \\
\hline & $(81,3)$ & $(46,2)$ & $(102)$ & $(121)$ & $(106)$ \\
\hline \multirow[t]{2}{*}{ As-gehalte strooisel ( $\mathrm{g} / \mathrm{kg})$} & 60,2 & 53,4 & 68,3 & 67,6 & 68,2 \\
\hline & $(10,8)$ & $(9,5)$ & $(11,6)$ & $(9,71)$ & $(10,0)$ \\
\hline \multirow[t]{2}{*}{ Ntot-gehalte strooisel (g/kg) } & 12,4 & 14,9 & 22,4 & 17,8 & 18,5 \\
\hline & $(3,85)$ & $(2,71)$ & $(3,33)$ & $(2,77)$ & $(2,99)$ \\
\hline \multirow[t]{2}{*}{$\mathrm{NH} 4-\mathrm{N}$-gehalte strooisel $(\mathrm{g} / \mathrm{kg})$} & 3,11 & 3,21 & 2,84 & 1,88 & 2,30 \\
\hline & $(1,02)$ & $(0,95)$ & $(0,93)$ & $(0,83)$ & $(1,16)$ \\
\hline \multirow[t]{2}{*}{ P-gehalte strooisel $(\mathrm{g} / \mathrm{kg})$} & 4,14 & 3,63 & - & - & - \\
\hline & $(0,772)$ & $(0,695)$ & & & \\
\hline \multirow[t]{2}{*}{$\mathrm{K}$-gehalte strooisel $(\mathrm{g} / \mathrm{kg})$} & - & - & 15,1 & 11,1 & 11,4 \\
\hline & & & $(2,49)$ & $(2,40)$ & $(2,24)$ \\
\hline \multicolumn{6}{|l|}{ Ammoniakemissie } \\
\hline \multirow[t]{2}{*}{ NH3-emissie ( $\mathrm{g} / \mathrm{d}$ per vleeskuiken) } & 0,667 & 0,361 & 1,464 & 0,175 & 0,151 \\
\hline & $(0,222)$ & $(0,264)$ & $(0,853)$ & $(0,117)$ & $(0,111)$ \\
\hline
\end{tabular}

a) Om een goede vergelijking met de andere ronden mogelijk te maken zijn de gemiddelden ook berekend na 5 weken groeiperiode. De gehele groeiperiode duurde 6 weken in ronde 4 , terwijl dit 5 weken was in ronden 1 - 3 .

Uit tabel 15 blijkt dat er grote verschillen zijn tussen de verschillende ronden voor wat betreft de feces- en strooiselsamenstelling en strooiselhoeveelheid en ammoniakemissie. Gedurende de eerste twee ronden was het strooisel zeer nat. Het ds-gehalte van het strooisel was gedurende deze ronden beduidend lager dan in ronden 3 en 4 en de rulheid was veel slechter (lagere score). De hoeveelheid strooisel(mest) was aan het eind van ronde 1 en 2 dan ook veel groter dan in ronde 3 . In ronde 4 is de hoeveelheid niet gemeten na 5 weken, maar na 6 weken groeiperiode was de hoeveelheid strooisel(mest) vergelijkbaar met de hoeveelheden in ronde 1 en 2 na 5 weken.

Het as-gehalte is enigszins verhoogd in ronde 3 en 4 en het Ntot-gehalte is beduidend hoger in ronden 3 en 4 . Het NH4- $\mathrm{N}$-gehalte van het strooisel is echter lager in ronde 3 en 4 ten opzichte van de eerste twee ronden. De $\mathrm{pH}$ van het strooisel varieerde sterk tussen de verschillende ronden. In ronde 1 was deze het hoogst met een gemiddelde waarde van 8,33 en in ronde 2 het laagst met een gemiddelde waarde van 6,17. De pH's in ronden 3 en 4 waren vergelijkbaar met gemiddelde waarden van respectievelijk 7,12 en 7,16. Tussen de gehalten van de feces in ronden 3 en 4 zitten geen opvallende verschillen. Het meest opvallende in tabel 15 is het grote verschil in ammoniakemissie tussen de 
verschillende ronden, waarbij het meest extreme verschil werd gevonden tussen ronden 3 en 4 . Deze twee ronden waren vrijwel geheel vergelijkbaar qua behandelingen. Desondanks was de gemiddelde ammoniakemissie in ronde 3 bijna een factor 10 hoger dan in ronde 4 . Ook ronden 1 en 2 waren zeer vergelijkbaar ten aanzien van de ingestelde behandelingen en ook hier zien we een vrij groot verschil in ammoniakemissie (ca. een factor 2).

De lineaire effecten van eiwit- en K-gehalte op de feces- en strooiselsamenstelling en - hoeveelheid en op de ammoniakemissie zijn weergegeven in tabel 16.

Tabel 16 Lineaire effecten van eiwit- en kaliumgehalte $(\mathrm{g} / \mathrm{kg})$ op de rulheid van het strooisel, op de feces- en strooiselsamenstelling en - hoeveelheid en op de ammoniakemissie. Tussen haakjes is de standaard fout van de regressiecoëfficiënt weergegeven. Tevens zijn de Pwaarden van de regressiecoëfficiënten weergegeven, waarbij de coëfficiënten die significant verschillend zijn van nul $(P<0,05)$ vet zijn gedrukt.

\begin{tabular}{|c|c|c|}
\hline Kenmerk & Eiwitgehalte & Kaliumgehalte \\
\hline Rulheid strooisel (score 0 - 10) & $-0,0048(0,0158) ; P=0,763$ & $-1,028(0,1054) ; \mathbf{P}<\mathbf{0 , 0 0 1}$ \\
\hline $\begin{array}{l}\text { Hoeveelheid strooisel(mest) eind } \\
\text { groeiperiode }(\mathrm{kg} / \mathrm{hok})\end{array}$ & $0,0276(0,0913) ; P=0,466$ & $2,010(0,5355) ; \mathbf{P}<\mathbf{0 , 0 0 1}$ \\
\hline $\mathrm{pH}$ strooisel & $0,0002(0,0063) ; P=0,976$ & $-0,003(0,042) ; P=0,940$ \\
\hline Ds-gehalte strooisel $(\mathrm{g} / \mathrm{kg})$ & $-1,042(0,6226) ; P=0,096$ & $-39,62(4,330) ; \mathbf{P}<\mathbf{0 , 0 0 1}$ \\
\hline As-gehalte strooisel $(\mathrm{g} / \mathrm{kg})$ & $-0,228(0,086) ; \mathbf{P}<\mathbf{0 , 0 0 1}$ & $-5,54(0,57) ; \mathbf{P}<\mathbf{0 , 0 0 1}$ \\
\hline Ntot-gehalte strooisel ( $\mathrm{g} / \mathrm{kg})$ & $0,111(0,024) ; \mathbf{P}<\mathbf{0 , 0 0 1}$ & $-2,02(0,16) ; \mathbf{P}<\mathbf{0 , 0 0 1}$ \\
\hline NH4-N-gehalte strooisel ( g/kg) & $0,0343(0,0069) ; \mathbf{P}<\mathbf{0 , 0 0 1}$ & $-0,345(0,046) ; \mathbf{P}<\mathbf{0 , 0 0 1}$ \\
\hline P-gehalte strooisel $(\mathrm{g} / \mathrm{kg})$ & $-0,0053(0,0319) ; P=0,868$ & $-0,428(0,052) ; \mathbf{P}<\mathbf{0 , 0 0 1}$ \\
\hline K-gehalte strooisel $(\mathrm{g} / \mathrm{kg})$ & $-0,0363(0,0227) ; P=0,113$ & $0,416(0,208) ; \mathbf{P}=\mathbf{0 , 0 4 9}$ \\
\hline Ds-gehalte uitgescheiden mest $(\mathrm{g} / \mathrm{kg})$ & $0,200(0,365) ; P=0,584$ & $-11,8(3,3) ; \mathbf{P}<\mathbf{0 , 0 0 1}$ \\
\hline As-gehalte uitgescheiden mest $(\mathrm{g} / \mathrm{kg})$ & $-0,0632(0,064) ; P=0,329$ & $-1,62(0,58) ; \mathbf{P}=\mathbf{0 , 0 0 6}$ \\
\hline Ntot-gehalte uitgescheiden mest $(\mathrm{g} / \mathrm{kg})$ & $0,115(0,020) ; \mathbf{P}<\mathbf{0 , 0 0 1}$ & $-0,827(0,180) ; \mathbf{P}<\mathbf{0 , 0 0 1}$ \\
\hline NH4- $\mathrm{N}$-gehalte uitgescheiden mest $(\mathrm{g} / \mathrm{kg})$ & $0,0090(0,0019) ; \mathbf{P}<\mathbf{0 , 0 0 1}$ & $-0,134(0,017) ; \mathbf{P}<\mathbf{0 , 0 0 1}$ \\
\hline K-gehalte uitgescheiden mest $(\mathrm{g} / \mathrm{kg})$ & $-0,0184(0,0105) ; P=0,084$ & $0,682(0,095) ; \mathbf{P}<\mathbf{0 , 0 0 1}$ \\
\hline NH3-emissie (mg/(m².uur)) & $-3,76(2,29) ; P=0,101$ & $-10,4(15,0) ; P=0,488$ \\
\hline
\end{tabular}

Uit tabel 16 blijkt dat het K-gehalte in het voer invloed heeft op vrijwel alle feces- en strooiselvariabelen. Dit heeft waarschijnlijk vooral met het feit te maken dat een hoger K-gehalte zorgt voor een verhoogde wateropname en meer wateruitscheiding met de feces en daarmee voor meer water in het strooisel. Dit heeft effect op alle concentraties in zowel de feces als het strooisel.

Het eiwitgehalte beïnvloedt de verschillende variabelen op een zelfde wijze als het K-gehalte, namelijk een hoger eiwitgehalte in het voer geeft lagere concentraties van de verschillende componenten in zowel de feces als het strooisel, waarschijnlijk ook als gevolg van een hogere wateruitscheiding. De hoeveelheid strooisel(mest) neemt om voorgaande reden dan ook toe bij hogere eiwit- en K-gehalten. Een hoger eiwitgehalte in het voer geeft hogere Ntot en $\mathrm{NH} 4-\mathrm{N}$ gehalten van de uitgescheiden mest en het strooisel. Hogere K-gehalten in het voer geeft hogere K-gehalten van de uitgescheiden mest en het strooisel. Opvallend is dat zowel het eiwit- als het K-gehalte geen significant effect hebben op de ammoniakemissie uit het strooisel. Analyse van de ammoniakemissie op log-schaal laat hetzelfde beeld zien. De gemiddelde ammoniakemissie per $\mathrm{m}^{2}$ strooiseloppervlakte was $476 \mathrm{mg} /\left(\mathrm{m}^{2}\right.$.uur).

Er was een sterk ronde-effect op de ammoniakemissie $(P<0,001)$ met emissies van 463, 250, 1016 en $101 \mathrm{mg} /\left(\mathrm{m}^{2}\right.$.uur) voor respectievelijk ronde $1 \mathrm{t} / \mathrm{m} \mathrm{4}$. Er was een significant verschil in het verloop van de ammoniakemissie tijdens de verschillende ronden $(P<0,001)$. De lineaire regressiecoëfficiënten voor de ammoniakemissie met dagnummer waren respectievelijk 12,2 voor ronde 1, 13,8 voor ronde 2, - 38, 9 voor ronde 3 en $-5,0$ voor ronde 4 (s.e.d. 7,5).

De analyse van de effecten van strooiselsamenstelling en ventilatiedebiet in de meetbox op de natuurlijke logaritme van de ammoniakemissie geeft de regressie-coëfficiënten zoals weergegeven in tabel 17. 
Tabel 17 Lineaire effecten van strooiselsamenstelling en ventilatiedebiet in de meetbox op de natuurlijke logaritme van de ammoniakemissie

\begin{tabular}{lcc} 
Variabele & Regressie-coëfficënt (s.e.) & P-waarde \\
\hline Rulheid strooisel (-) & $0,112(0,020)$ & $<0,001$ \\
\hline pH strooisel $(-)$ & $0,250(0,072)$ & $<0,001$ \\
\hline Ntot strooisel $(\mathrm{g} / \mathrm{kg})$ & $-0,030(0,017)$ & 0,078 \\
\hline NH4-N strooisel $(\mathrm{g} / \mathrm{kg})$ & $0,052(0,060)$ & 0,383 \\
\hline Temp. strooisel $\left({ }^{\circ} \mathrm{C}\right)^{1)}$ & $0,075(0,035)$ & 0,032 \\
\hline Ventilatiedebiet meetbox $\left(\mathrm{m}^{3} / \mathrm{uur}\right)$ & $0,0223(0,0039)$ & $<0,001$
\end{tabular}

1) Niet gemeten in ronde 1

Uit deze analyse blijkt dat de effecten van rulheid en $\mathrm{pH}$ van het strooisel sterk significant waren. Rulheid en ds-gehalte van het strooisel zijn sterk verstrengeld met elkaar, echter rulheid verklaart een veel groter deel van de variatie in ammoniakemissie dan ds-gehalte. Bij elke verbetering van de strooiselkwaliteit met 1 eenheid in de rulheidsscore steeg de ammoniakemissie met ca. $11 \%$ en bij elke stijging van de $\mathrm{pH}$ met 1 eenheid steeg de ammoniakemissie met ca. $25 \%$ en. Het Ntot en het $\mathrm{NH} 4-\mathrm{N}$ gehalte van het strooisel hadden beiden geen significant effect op de ammoniakemissie. Het effect van strooiseltemperatuur was net significant, bij elke stijging van de temperatuur met $1^{\circ} \mathrm{C}$ steeg de ammoniakemissie met ca. 7,5\%. Het ventilatiedebiet in de meetbox had een sterk effect op de ammoniakemissie, bij elke $1 \mathrm{~m}^{3} /$ uur stijging van het ventilatiedebiet steeg de ammoniakemissie met ca. 2,2\%. Ook in deze analyse werd echter het overgrote deel van de variatie verklaard door verschillen tussen ronden $(P<0,001)$. Ook was er een significant interactie-effect tussen ronde en dagnummer $(\mathrm{P}<0,001)$. 


\section{$4 \quad$ Beschrijving rekentool}

Om het effect van voermaatregelen op de ammoniakemissie te kunnen bepalen moet de rekentool gericht zijn op het doorrekenen van de gehele keten van voeropname door het vleeskuiken, het metabolisme in het vleeskuiken, de uitscheiding door het vleeskuiken en de veranderingen in het strooisel als gevolg van stalklimaat en fysisch/chemische/biologische processen, zoals omzettingen en vervluchtiging. In figuur 4 wordt de opbouw van de rekentool schematisch weergegeven, met daarin de belangrijkste input, output en te berekenen modelvariabelen.

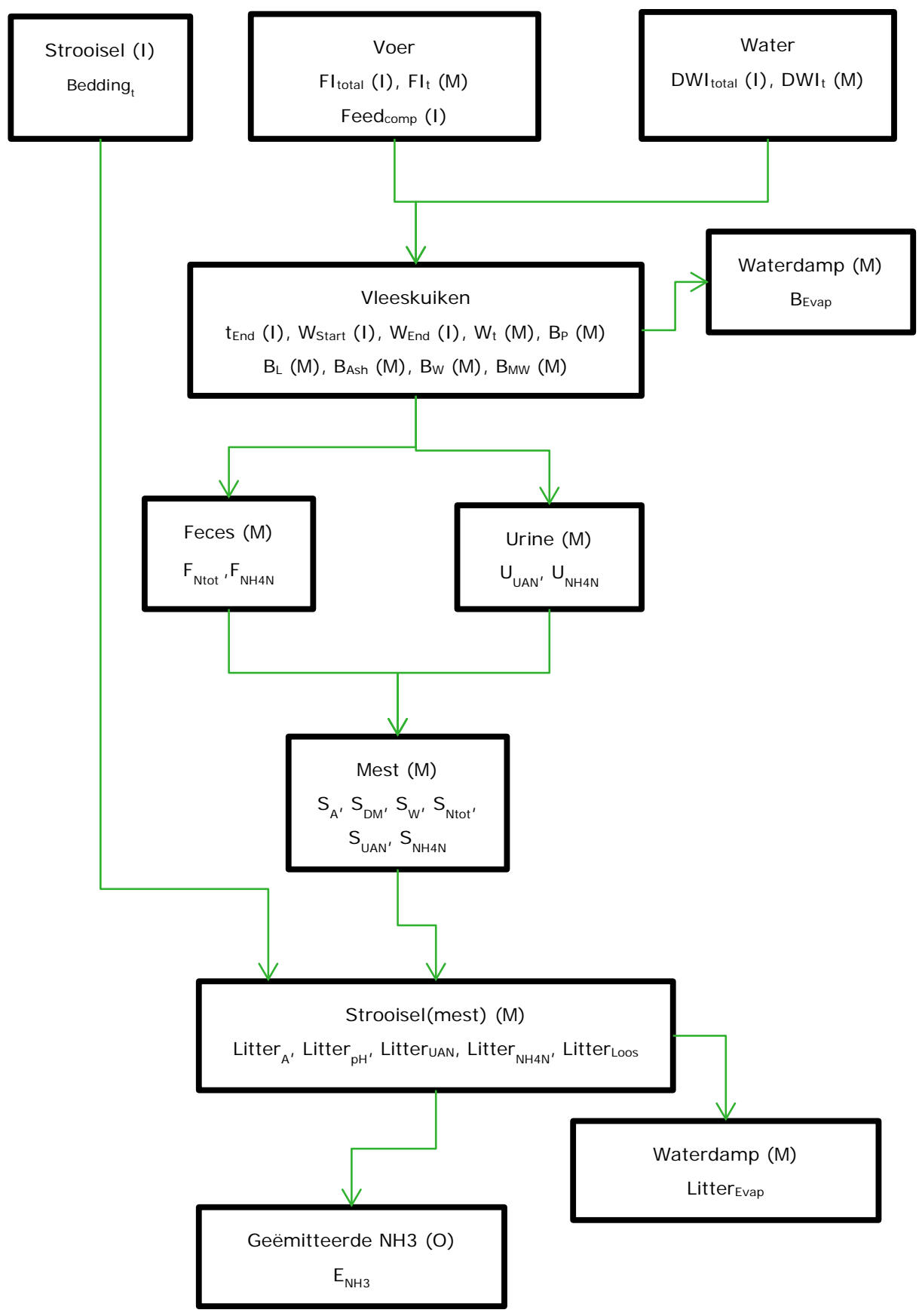

Figuur 4 Schematische weergave van de opbouw van de rekentool voor ammoniakemissie uit vleeskuikenstallen waarin de belangrijkste input $(\mathrm{I})$, output $(\mathrm{O})$ en intern te berekenen modelvariabelen (M) zijn weergegeven. Voor uitleg van de symbolen zie tabel 18. 
Tabel 18 De betekenis van de gebruikte symbolen in figuur 4. Alles is uitgedrukt per vleeskuiken, voor zover relevant

\begin{tabular}{|c|c|c|c|}
\hline Symbool & Betekenis & Symbool & Betekenis \\
\hline BAsh & Aanzet anorganische stof $(\mathrm{kg} / \mathrm{d})$ & LitterLoos & Rulheid strooisel(mest) (-) \\
\hline $\mathrm{B}_{\mathrm{L}}$ & Vetaanzet $(\mathrm{kg} / \mathrm{d})$ & Litter $_{\mathrm{pH}}$ & $\mathrm{pH}$ strooisel(mest) (-) \\
\hline $\mathrm{Bp}_{\mathrm{p}}$ & Eiwitaanzet $(\mathrm{kg} / \mathrm{d})$ & $\mathrm{S}_{\mathrm{A}}$ & Mestproductie (feces + urine) $(\mathrm{kg} / \mathrm{d})$ \\
\hline $\mathrm{B}_{\mathrm{w}}$ & Wateraanzet $(\mathrm{kg} / \mathrm{d})$ & SDM & Drogestofuitscheiding in mest $(\mathrm{kg} / \mathrm{d})$ \\
\hline $\mathrm{DWI}_{\mathrm{t}}$ & Drinkwateropname op dag $\mathrm{t}(\mathrm{kg} / \mathrm{d})$ & $\mathrm{S}_{\text {Ntot }}$ & Totaal stikstof uitscheiding in mest $(\mathrm{kg} / \mathrm{d})$ \\
\hline $\mathrm{DWI}_{\text {total }}$ & $\begin{array}{l}\text { Totale drinkwateropname tijdens } \\
\text { groeiperiode }(\mathrm{kg})\end{array}$ & SUAN & $\begin{array}{l}\text { Urinezuur stikstof uitscheiding in mest } \\
(\mathrm{kg} / \mathrm{d})\end{array}$ \\
\hline $\mathrm{E}_{\mathrm{NH} 3}$ & Ammoniakemissie (mg/uur) & Sw & Wateruitscheiding in mest $(\mathrm{kg} / \mathrm{d})$ \\
\hline $\mathrm{F}_{\mathrm{NH} 4 \mathrm{~N}}$ & $\begin{array}{l}\text { Totaal ammoniumstikstof uitscheiding } \\
\text { via feces }(\mathrm{kg} / \mathrm{d})\end{array}$ & $t_{E n d}$ & Groeiperiode vleeskuikens (dagen) \\
\hline $\mathrm{F}_{\text {Ntot }}$ & $\begin{array}{l}\text { Totaal stikstof uitscheiding via feces } \\
(\mathrm{kg} / \mathrm{d})\end{array}$ & $U_{\text {Ntot }}$ & $\begin{array}{l}\text { Totaal stikstof uitscheiding via urine } \\
(\mathrm{kg} / \mathrm{d})\end{array}$ \\
\hline Litter $_{A}$ & Hoeveelheid strooisel(mest) (kg) & $\mathrm{W}_{\mathrm{t}}$ & Gewicht vleeskuiken op dag t (kg) \\
\hline LitterEvap & $\begin{array}{l}\text { Waterverdamping uit strooisel(mest) } \\
(\mathrm{kg} / \mathrm{d})\end{array}$ & & \\
\hline
\end{tabular}

1) v.c. = verteringscoëfficiënt

2) Voercomponenten: water, ruw-eiwit, ruw-vet, ruwe celstof, as, fosfor, kalium en overige koolhydraten.

Belangrijk bij de ontwikkeling van de rekentool was te bepalen welke informatie vanuit de vleeskuikenhouderij beschikbaar is om als input te dienen voor het model. Bij deze analyse zijn we uitgekomen op de volgende inputvariabelen:

- duur groeiperiode

- begin- en eindgewicht vleeskuikens

- totale voeropname over de hele groeiperiode

- totale wateropname over de hele groeiperiode

- voersamenstelling (gehalten aan ruw eiwit, ruw vet, ruwe celstof, as, fosfor, kalium en verteringscoëfficiënten van ruw(e) eiwit, ruw vet en ruwe celstof en overige koolhydraten) hoeveelheid strooiselmateriaal bij de start van de groeiperiode en eventueel tijdens de groeiperiode, maar dat is in de praktijk niet gebruikelijk

De rekentool voert de berekeningen uit over tijdsperioden van één dag en doet dit gedurende de gehele groeiperiode. Voor een aantal parameters in het model zijn kalibraties uitgevoerd op eigen meetdata. Dat wil zeggen dat de waarde van een parameter (b.v. een regressiecoëfficiënt) is aangepast op basis van de beste fit op de gemeten data. De gekalibreerde parameters zijn gekalibreerd met gegevens van ronde 4, aangezien van deze ronde de meeste gegevens beschikbaar waren (de mestproductie was alleen in deze ronde beschikbaar). 
De parameters voor het berekenen van de waterverdamping en de omzettingssnelheid van urinezuur zijn gekalibreerd met gegevens van alle ronden, omdat de variatie voor deze variabelen vooral tussen ronden aanwezig was en in veel mindere mate binnen een ronde. In de verschillende figuren worden steeds de resultaten van alle ronden weergegeven, dus zowel de resultaten van ronde 4 die vooral voor de kalibratie zijn gebruikt als van de andere ronden.

In de hiernavolgende paragrafen worden de verschillende schakels in de keten van de ontwikkelde rekentool beschreven. In paragraaf 3.1 wordt het gewichtsverloop van de vleeskuikens en de voer- en wateropname gemodelleerd, in paragraaf 3.2 de hoeveelheden en concentraties van de uitgescheiden componenten in de mest en in paragraaf 3.3 de processen die optreden in het strooisel. Er wordt in de paragrafen steeds aangegeven wanneer de vergelijkingen en parameter-waarden zijn verkregen door middel van kalibratie. Wanneer parameters in het rekenmodel zijn gekalibreerd, dan is dit gedaan met behulp van de kleinste kwadraten methode, volgens de volgende formule:

$G K_{\text {var }}=\sum_{1}^{n}\left(\frac{\left(\text { var }_{\text {gemeten }}-\text { var }_{\text {berekend }}\right)}{\text { var }_{\text {gemeten }}}\right)^{2} / n$

Waarin: GKvar is het gemiddelde kwadraat van het relatieve verschil tussen gemeten en berekende waarden

var $_{\text {gemeten }}$ is de gemeten waarde van de variabele

var berekend is de berekende waarde van de variabele

$\mathrm{n}$ is het aantal waarnemingen

De kleinste waarde van GKvar werd beschouwd als de beste fit voor de betreffende parameter of combinatie van parameters.

\subsection{Gewichtsverloop vleeskuikens en voer en wateropname}

Groeicurves worden vaak beschreven met een Gompertz-curve. Dit is een S-vormige curve met in het begin van de groeiperiode een exponentiële toename van het gewicht, vervolgens een afnemende toename, om tenslotte te stabiliseren op het volwassen eindgewicht. De Gompertz-curve ziet er als volgt uit:

$W_{t}=W_{m} \cdot \exp \left\{-\exp \left[-B\left(t-t^{*}\right)\right]\right\} / 1000$

Waarin: $W_{t}$ is het gewicht van het dier op tijdstip $t(\mathrm{~kg})$

$\mathrm{W}_{\mathrm{m}}$ is het volwassen eindgewicht van het dier $(\mathrm{kg})$

$B$ is een parameter die de vorm van de groeicurve bepaald (deze bepaalt de snelheid van het bereiken van het eindgewicht $\left(\right.$ dag $\left.^{-1}\right)$

$\mathrm{t}^{*}$ is het tijdstip waarop de groei maximaal is (dag)

$1000=$ omrekening van gram naar kilogram

Gous et al. (1999) hebben de parameters in de Gompertz-curve bepaald voor twee genotypen en voor hanen en hennen. Vleeskuikens zijn sinds 1999 echter genetisch alweer sterk veranderd, daarom hebben we de parameters van de Gompertz-curve op basis van de eigen metingen (in ronde 4) bepaald. In tabel 19 worden de geschatte parameters weergegeven en vergeleken met de waarden gegeven door Gous et al. (1999). Uit deze tabel blijkt dat de waarden van de parameters sterk zijn veranderd in de afgelopen jaren. De maximale groeisnelheid wordt op jongere leeftijd bereikt en het volwassen eindgewicht wordt sneller bereikt (hogere B). Ook het geschatte volwassen eindgewicht is veel hoger. Echter, deze schatting is zeer onnauwkeurig (hoge standaard deviatie).

Aangezien we het totale eindgewicht echter weten (= input), kunnen we één parameter van de Gompertz-curve schatten. Aangezien $W_{m}$ de grootste variatie laat zien en ook moeilijk te schatten is met data van vleeskuikens (ze bereiken het volwassen eindgewicht niet), maken we deze parameter variabel in het rekenmodel. Dit betekent dat $W_{m}$ zodanig wordt gefit dat het eindpunt van de groeicurve precies gelijk is aan het gemeten eindgewicht van de vleeskuikens (input in model). 
Tabel 19 Geschatte parameters van de Gompertz-curve (zie vergelijking 9), voor berekening van het gewicht van vleeskuiken, met behulp van eigen data uit ronde 4 en parameterwaarden van Gous et al. (1999). Tussen haakjes zijn de standaard deviaties weergegeven.

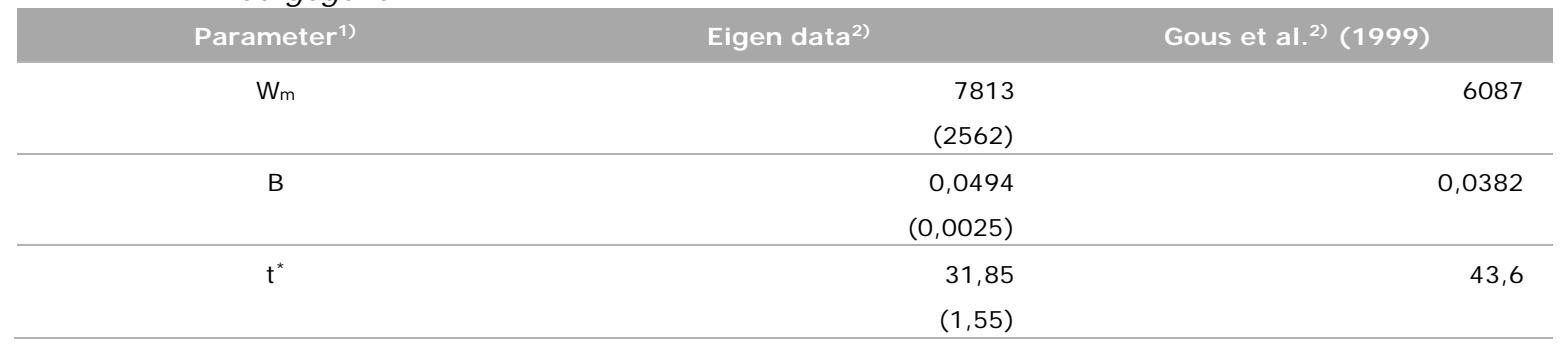

1) Voor verklaring van de variabelen zie formule 1.

2) Deze parameters berekenen het gewicht in gram. Voor omrekening naar kilogram wordt in formule 9 gedeeld door 1000

Tabel 20 Geschatte parameters van de Gompertz-curve (zie vergelijking 9), voor berekening van het verloop van de totale voer- en drinkwateropname, met behulp van eigen data uit ronde 4. Tussen haakjes zijn de standaard deviaties weergegeven.

\begin{tabular}{|c|c|c|}
\hline Parameter ${ }^{1)}$ & $\begin{array}{c}\text { Voeropname } 2) \\
\text { (g) }\end{array}$ & $\begin{array}{c}\text { Drinkwateropname }{ }^{2)} \\
\text { (g) }\end{array}$ \\
\hline \multirow[t]{2}{*}{$\mathrm{Fl}_{\mathrm{m}} / \mathrm{DWI} \mathrm{m}$} & 15000 & 36000 \\
\hline & $(5200)$ & $(8300)$ \\
\hline \multirow[t]{2}{*}{ B } & 0,0420 & 0,0406 \\
\hline & $(0,0022)$ & $(0,0031)$ \\
\hline \multirow[t]{2}{*}{$t^{*}$} & 41,90 & 40,91 \\
\hline & $(1,95)$ & $(3,26)$ \\
\hline
\end{tabular}

1) $\mathrm{FIm}$ en DWIm zijn de parameters voor voer- en drinkwateropname, vergelijkbaar met $\mathrm{W}_{\mathrm{m}}$ voor de groeicurve. In tegenstelling tot de groeicurve blijven de voer- en wateropname niet onder een bepaalde asymptoot, maar nemen op een gegeven moment min of meer lineair toe in de tijd. Voor verklaring van de overige variabelen zie formule 1.

2) Voor verdere modelberekeningen zijn de berekende voer- en wateropnames omgerekend van gram naar kilogram.

Het verloop van de totale voer- en drinkwateropname laat ook een S-vormig verloop zien. Daarom beschrijven we dit verloop ook met de Gompertz-curve. Een verschil met het verloop van het diergewicht is dat het diergewicht een asymptoot kent, namelijk bij het volwassen eindgewicht ( groei $=0$ ), terwijl de voer- en drinkwateropname per dag op een gegeven moment min of meer constant is en de totale voer- en drinkwateropname lineair toeneemt met de tijd. Voor vleeskuikens hoeft dit laatste deel van de curve echter niet beschreven te worden, omdat de dieren het volwassen gewicht niet bereiken, waardoor de Gompertz-curve ook voldoet voor beschrijving van de voer-en wateropname. De geschatte parameters van de curves voor voer- en wateropname worden gegeven in tabel 20. Ook bij deze curves kunnen we één parameter schatten, omdat we de totale voer- en wateropname gedurende de gehele groeiperiode als input benutten. Net als voor het gewichtsverloop, maken we de parameters $\mathrm{FI}_{\mathrm{m}}$ en $\mathrm{DWI}$ variabel in het rekenmodel.

Figuur 5 toont de $\mathrm{Y}=\mathrm{X}$ relatie tussen de berekende en de gemeten waarden van het cumulatieve gewicht (in gram) en de cumulatieve voer- en wateropname (in gram). De constanten verschilden niet significant van 0 en de regressiecoëfficiënten verschilden niet significant van 1 . Alle drie de curven hadden een $\mathrm{R}^{2}>0,998$. In figuur 6 wordt het gemiddelde verloop van de gemeten en berekende waarden gedurende de groeiperiode weergegeven. Hieruit blijkt dat het verloop van het gewicht en voer- en wateropname goed door de curves wordt beschreven. 


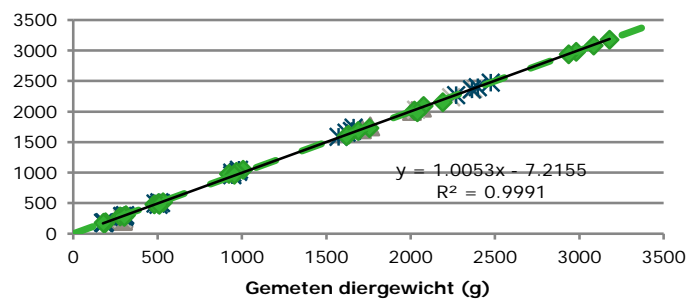

(a)

$\triangle \mathrm{R} 1 \times \mathrm{R} 2 \times \mathrm{R} 3 \bullet \mathrm{R} 4$

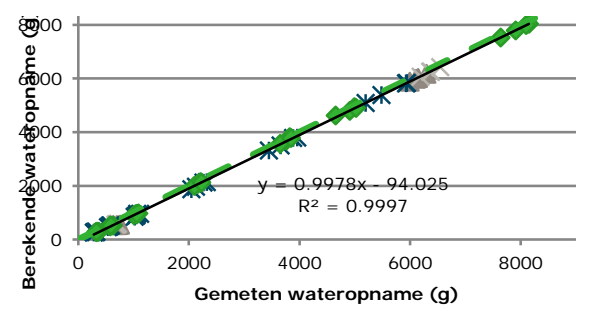

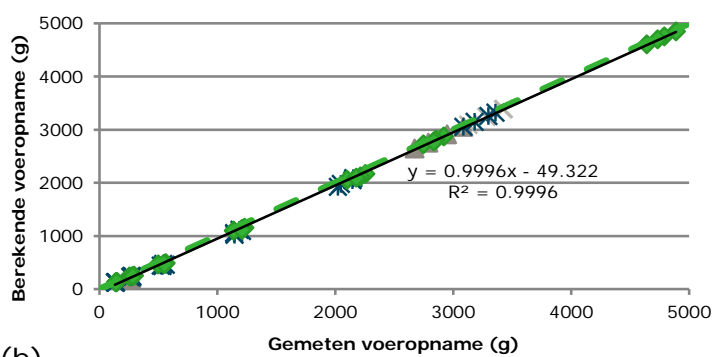

(b)

$\triangle \mathrm{R} 1 \times \mathrm{R} 2 \quad \times \mathrm{R} 3 \diamond \mathrm{R} 4$

(c)

Figuur 5 Vergelijking tussen berekende $(Y)$ en gemeten $(X)$ waarden voor het cumulatieve diergewicht (a), voeropname (b) en drinkwateropname (c) (g per vleeskuiken) in de verschillende ronden ( $R 1 \mathrm{t} / \mathrm{m} \mathrm{R} 4)$ ). Elk punt is het gemiddelde van 4 hokken met dezelfde behandeling. De dunne zwarte lijn is de regressielijn, waarvan de formule in de figuren is weergegeven, en de groene gestippelde lijn is de $Y=X$ lijn.

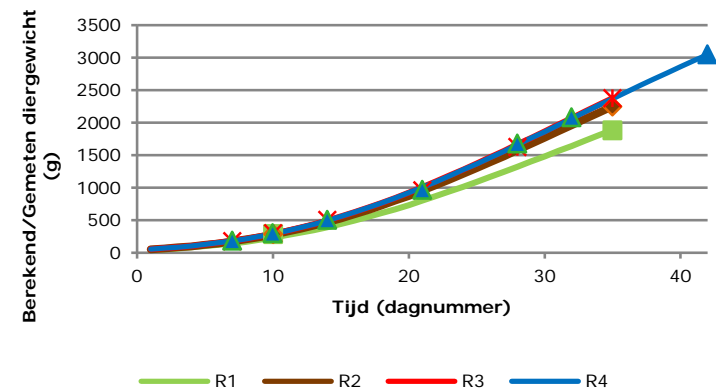

(a)

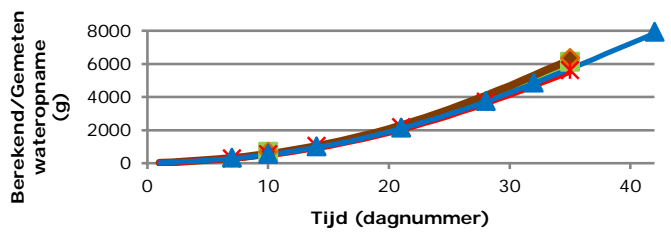

$\longrightarrow \mathrm{R} 1 \longrightarrow \mathrm{R} 2 \longrightarrow \mathrm{R} 3$

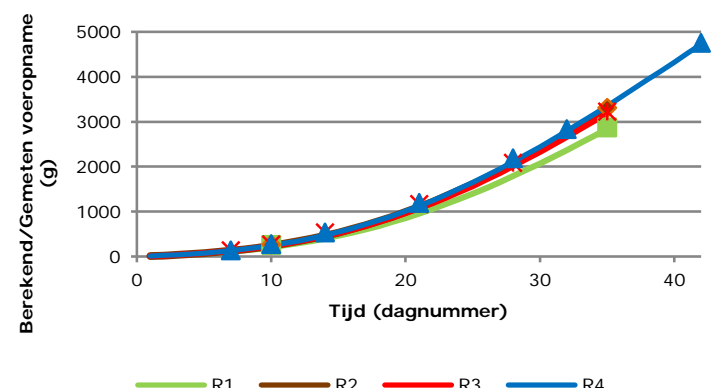

(b)

(c)

Figuur 6 Gemeten (punt) en berekend (lijn) verloop van het cumulatieve diergewicht (a), voeropname (b) en drinkwateropname (c) in g per vleeskuiken in de verschillende ronden ( $R 1 \mathrm{t} / \mathrm{m}$ R4). Elk punt is het gemiddelde van 4 hokken met dezelfde behandeling. In R1 en R2 is het gewicht tijdens de overgang en op het eind bepaald, terwijl dit in R3 en R4 wekelijks is gedaan. 


\subsection{Hoeveelheid en samenstelling van de uitgescheiden mest}

Om de hoeveelheid en de samenstelling van de uitgescheiden mest te bepalen wordt eerst de aanzet in het dier bepaald van eiwit, vet, as en water. De samenstelling van de groei wordt bepaald met behulp van de energie- en de massabalans. De waterverdamping door het dier wordt berekend uit de latente warmteafgifte.

In de hierna volgende formules wordt de energie- en massabalans gebruikt om de groeisamenstelling te berekenen. De eiwit- en de vetaanzet blijven uiteindelijk over als twee onbekenden die met behulp van de energie- en de massabalansformules kunnen worden berekend.

De hoeveelheid metaboliseerbare energie in het voer kan berekend worden uit de voersamenstelling (Anonymous, 2011), wat input is voor het model:

$M E_{\text {feed }}=15,56$ vre $+38,83$ vrvet $+17,32$ vok

Waarin: $\mathrm{ME}_{\mathrm{feed}}$ is het gehalte aan metaboliseerbare energie in het voer $(\mathrm{MJ} / \mathrm{kg})$

vre is het verteerbaar ruw-eiwit gehalte $(\mathrm{kg} / \mathrm{kg})$

vrvet is het verteerbaar ruw-vet gehalte $(\mathrm{kg} / \mathrm{kg})$

vok is het gehalte aan verteerbaar overige koolhydraten $(\mathrm{kg} / \mathrm{kg})$

De metaboliseerbare energieopname per dag is gelijk aan het gehalte in het voer maal de voeropname per dag. Deze energieopname is tevens gelijk aan de som van de energie voor onderhoud en de energie beschikbaar voor productie (groei in geval van de vleeskuikens) (Kielanowski, 1965):

$M E_{\text {intake }}=M E_{m}+M E_{\text {prod }}$

Waarin: $M E_{\text {intake }}$ is opname aan metaboliseerbare energie (MJ/d)

MEm is metaboliseerbare energie voor onderhoud $(\mathrm{MJ} / \mathrm{d})$

$\mathrm{ME}_{\text {prod }}$ metaboliseerbare energie beschikbaar voor groei (MJ/d)

De benodigde energie voor onderhoud $\left(\mathrm{MEm}_{\mathrm{m}}\right)$ kan als volgt worden berekend (Lopez \& Leeson, 2008):

$M E_{m}=155,3 W^{0,66} \cdot \frac{4,184}{1000}$

Waarin: $\quad M E_{m}$ is metaboliseerbare energie voor onderhoud $(\mathrm{MJ} / \mathrm{d}$ )

$\mathrm{W}$ is diergewicht, bepaald in formule $9(\mathrm{~kg})$

$4,184 / 1000$ is de omrekeningsfactor van kcal naar MJ

De metaboliseerbare energie voor groei kan als volgt worden berekend (Kielanowski, 1965):

$M E_{\text {prod }}=\frac{E_{P}}{k_{P}} \cdot B_{P}+\frac{E_{L}}{k_{L}} \cdot B_{L}$

Waarin: $\mathrm{ME}_{\text {prod }}$ is metaboliseerbare energie beschikbaar voor groei $(\mathrm{MJ} / \mathrm{d}$ )

$E_{P}$ is energie in eiwit $(\mathrm{MJ} / \mathrm{kg})$

$\mathrm{E}_{\mathrm{L}}$ is energie in vet $(\mathrm{MJ} / \mathrm{kg})$

$k_{P}$ is de efficiëntie van eiwitaanzet, de rest wordt omgezet in warmte (MJ/MJ)

$k_{L}$ is de efficiëntie van vetaanzet, de rest wordt omgezet in warmte (MJ/MJ)

$B_{P}$ is de eiwitaanzet $(\mathrm{kg} / \mathrm{d})$

$B_{L}$ is de vetaanzet $(\mathrm{kg} / \mathrm{d})$

Volgens Lopez en Leeson (2008) is de energie in aangezet vet gelijk aan 9,5 kcal/g ( $\left.E_{L}=39,75 \mathrm{MJ} / \mathrm{kg}\right)$ en de energie in aangezet eiwit 5,7 kcal/g $\left(E_{P}=23,85 \mathrm{MJ} / \mathrm{kg}\right)$. Volgens dezelfde auteurs is de energie-efficiëntie van eiwitaanzet $\left(k_{p}\right)$ 0,66 MJ / MJ en de energie-efficiëntie van vetaanzet $\left(k_{L}\right)$ 0,86 MJ/MJ. De eiwit- en vetaanzet kunnen nu met de volgende twee formules worden berekend:

$B_{P}=G \cdot f_{s c}-B_{L}-B_{A s h}-B_{W}$

Waarin: $B_{P}$ is de eiwitaanzet $(\mathrm{kg} / \mathrm{d})$

$\mathrm{G}$ is de groei $(\mathrm{kg} / \mathrm{d})$

$\mathrm{f}_{\mathrm{sc}}$ is de correctiefactor voor toename maagdarminhoud (-)

$B_{L}$ is de vetaanzet $(\mathrm{kg} / \mathrm{d})$

$B_{\text {Ash }}$ is de as-aanzet $(\mathrm{kg} / \mathrm{d})$

$B_{w}$ is de wateraanzet $(\mathrm{kg} / \mathrm{d})$ 
Vergelijking 13 kan herschreven worden zodanig dat de vetaanzet berekend kan worden uit de overige variabelen:

$B_{L}=\left(M E_{\text {prod }}-B_{P} \cdot \frac{E_{P}}{k_{P}}\right) /\left(\frac{E_{L}}{k_{L}}\right)$

Waarin: $B_{L}$ is de vetaanzet $(\mathrm{kg} / \mathrm{d})$

$\mathrm{ME}_{\text {prod }}$ is de metaboliseerbare energie beschikbaar voor groei $(\mathrm{MJ} / \mathrm{d}$ )

$B_{P}$ is de eiwitaanzet $(\mathrm{kg} / \mathrm{d})$

$E_{P} / E_{L}$ energie in eiwit en vet $(M J / k g)$

$\mathrm{k}_{\mathrm{P}}$ en $\mathrm{k}_{\mathrm{L}}$ efficiëntie-coëfficiënten voor eiwit- en vetaanzet, rest wordt omgezet in warmte (MJ/MJ)

De groei (G) kan bepaald worden uit de groeicurve. De toename van de maag- darminhoud ( $f_{s c}$ ) is afhankelijk van de leeftijd van de kuikens en is een bepaald percentage van de groei (Hancock et al., 1995); voor het groeitraject van 0-3, 4-10, 11-17, 18-eind zijn deze percentage respectievelijk 1,68, 3,94, 5,91 en 7,59\%. Volgens Gous et al. (1999) is de as-aanzet een bepaald percentage van de eiwitaanzet, namelijk $16,5 \%$.

$B_{A s h}=0,165 B_{P}$

Waarin: $\quad B_{A s h}$ is de as-aanzet $(\mathrm{kg} / \mathrm{d})$

$B_{p}$ is de eiwitaanzet $(\mathrm{kg} / \mathrm{d})$

$\mathrm{Er}$ is ook min of meer een vaste relatie tussen de eiwitaanzet en de aanzet van water. Volgens Gous et al. (1999) betreft dit een log-lineaire relatie die beschreven kan worden met de volgende formule:

$B_{W-\text { ratio }}=\exp \left(A+B \cdot B_{P}\right)$

Waarin: $\quad$ Bw_ratio is de verhouding tussen water- en eiwitaanzet (-)

$B_{p}$ is de eiwitaanzet $(\mathrm{kg} / \mathrm{d})$

Volgens Gous et al. (1999) zijn de parameters A en B afhankelijk van ras en sexe. Voor Ross ( $\overbrace{}^{\text {) }}$ x Arbor Acres ( + ) zijn de waarden voor hanen: $A=1,271$ en $B=0,917$; en voor hennen: $A=1,219$ en $B=0,897$. Deze regressielijn bleek echter slecht te fitten bij de eigen data, vooral in het begin van de groeiperiode werd de $\mathrm{N}$-excretie onderschat.

Daarom is op basis van eigen data van ronde 4 een regressielijn gefit. Hiervoor werd de $\mathrm{N}$-aanzet berekend uit het verschil tussen $\mathrm{N}$-opname en $\mathrm{N}$-excretie. De eiwitaanzet werd berekend door de $\mathrm{N}$-aanzet te vermenigvuldigen met 6,25. Met formules 11, 12 en 13 kon vervolgens de vet-aanzet worden berekend en met formule 16 de as-aanzet. Uiteindelijk kon met formule 14 de wateraanzet worden berekend. Het volgende model werd gefit op de data:

$B_{W-\text { ratio }}=A+C /(1+\operatorname{EXP}(-B *(L O G($ Dagnr $)-M)))$

Waarin: $\quad B_{W_{-}}$ratio is de verhouding tussen water- en eiwitaanzet (-)

De fit gaf de volgende coëfficiënten: $A=1,405$ (s.e. 1,07), $B=-1,920$ (s.e. 0,524), $C=5,277$ (s.e. 1,38 ), $M=$ 2,885 (s.e. 0,230 ). Deze fit verklaarde $88 \%$ van de variatie in de 'gemeten' verhouding tussen water- en eiwitaanzet. Zie figuur 7 voor twee voorbeelden van een fit met beide formules (17 en 18).
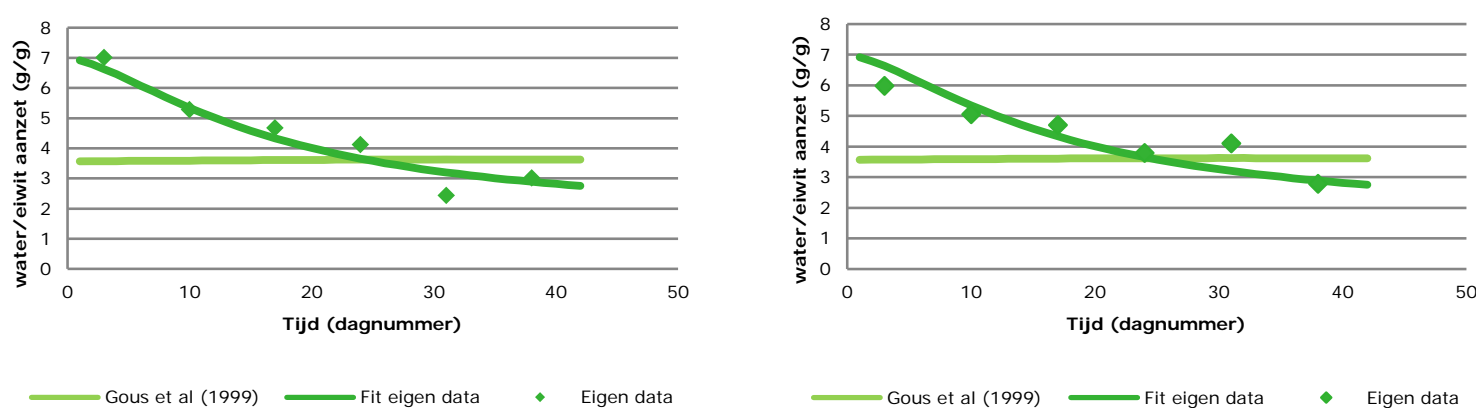

Figuur 7

Twee voorbeelden van de data-fit voor het verloop van de verhouding tussen water- en eiwitaanzet met formules gebaseerd op Gous et al. (1999; formule 17) en een eigen ontwikkelde formule gebaseerd op data uit ronde 4 (formule 18). De figuren laten de fit zien voor 2 van de 16 hokken (hok 1 en 2). 
De hoeveelheid water die uitgescheiden wordt in de mest van het vleeskuiken kan als volgt worden berekend:

$$
\begin{aligned}
& S_{W}=W I+B_{M W}-B_{W}-B_{\text {Evap }} \\
& W I=D W I+\text { Feed }_{W} \cdot F I
\end{aligned}
$$

Waarin: $S_{w}$ is de hoeveelheid uitgescheiden water in de mest $(\mathrm{kg} / \mathrm{d})$

$\mathrm{Wl}$ is de wateropname $(\mathrm{kg} / \mathrm{d})$

$B_{M W}$ is het gevormde metabolisch water (door oxidatie van organische stof), berekend in model $(\mathrm{kg} / \mathrm{d}$ )

$B_{w}$ is de wateraanzet, berekend in model $(\mathrm{kg} / \mathrm{d})$

BEvap is de waterverdamping, berekend in model $(\mathrm{kg} / \mathrm{d})$

DWI is de drinkwateropname, berekend met de Gompertz-curve $(\mathrm{kg} / \mathrm{d})$

Feedw is het watergehalte van het voer, input in het model $(\mathrm{kg} / \mathrm{kg})$

$\mathrm{FI}$ is de voeropname, berekend met de Gompertz-curve $(\mathrm{kg} / \mathrm{d})$

De hoeveelheid gevormd metabolisch water kan als volgt worden berekend uit de verteerde organische stofcomponenten en de aanzet van eiwit en vet (Aarnink et al., 1992):

$B_{M W}=0,556 \cdot(\operatorname{vrc}+$ vok $) \cdot F I+1,071 \cdot\left(\right.$ vrvet $\left.\cdot F I-B_{L}\right)+0,396 \cdot\left(\right.$ vre $\left.\cdot F I-B_{P}\right)$

Waarin: $\quad B_{M W}$ is de hoeveelheid gevormd metabolisch water $(\mathrm{kg} / \mathrm{d})$

vrc, vok, vrvet en vre zijn respectievelijk het gehalte in het voer aan verteerbare ruwe celstof, overige koolhydraten, ruw vet en ruw eiwit, dit zijn inputgegevens voor het model $(\mathrm{kg} / \mathrm{kg})$

$\mathrm{Fl}$ is de voeropname, berekend met de Gompertz-curve $(\mathrm{kg} / \mathrm{d})$

$B\llcorner$ en Bp zijn de vet- en eiwitaanzet $(\mathrm{kg} / \mathrm{d})$

De waterverdamping kan berekend worden uit de latente warmteafgifte:

$Q l=\left(1-f_{Q S}\right) \cdot Q t o t$

Waarin: QI is de latente warmteafgifte $(M J / d)$

$\mathrm{f}_{\mathrm{QS}}$ is het aandeel van de totale warmteproductie dat als sensibele warmte wordt afgegeven (MJ/MJ) Qtot is de totale warmteproductie (MJ/d)

Qtot kan berekend worden door de energie in de eiwit- en vetaanzet van de opgenomen metaboliseerbare energie (ME) af te trekken.

$Q$ tot $=M E-B_{P} \cdot E_{P}-B_{L} \cdot E_{L}$

Waarin: Qtot is de totale warmteproductie (MJ/d)

$M E$ is opname aan metaboliseerbare energie $(M J / d)$

$B_{p}$ is de eiwitaanzet $(\mathrm{kg} / \mathrm{d})$

$B_{L}$ is de vetaanzet $(\mathrm{kg} / \mathrm{d})$

$E_{p}$ is energie in eiwitaanzet $(\mathrm{MJ} / \mathrm{kg})$

$E_{L}$ is energie in vetaanzet $(\mathrm{MJ} / \mathrm{kg})$

Volgens de CIGR (CIGR, 2002) kan het aandeel sensibele warmteafgifte per geproduceerde HPU (heat producing unit $=1000$ Watt) op stalniveau als volgt worden berekend:

$f_{Q S-H P U}=0,61 \cdot(1000+20 \cdot(20-T i))-0,228 \cdot T i^{2}$

Waarin: $\quad f_{Q S-H P U}$ is het aandeel sensibele warmteafgifte per geproduceerde HPU (heat producing unit $=1000$ Watt $)(\mathrm{W} / \mathrm{kW})$ $\mathrm{Ti}$ is de omgevingstemperatuur van het $\operatorname{dier}\left({ }^{\circ} \mathrm{C}\right)$

Wij willen $f_{Q s}$ echter op dierniveau bepalen. Daarom is $f_{Q s}$ uit eigen data bepaald; de waterverdamping is bepaald door het totaal van wateraanzet ( $\mathrm{B}_{\mathrm{w}}$; berekend uit de gemeten $\mathrm{N}$-retentie, zie hierboven) en de gemeten waterhoeveelheid in de verse mest ( $\mathrm{Sw}_{w}$; berekend uit de mestproductie en ds-gehalte van de verse mest) af te trekken van het totaal van wateropname (drinkwater + voer; $W_{\text {total }}$ ) en metabolische water ( $B_{\text {Mw) }}$ (zie vergelijkingen $19 \mathrm{t} / \mathrm{m} \mathrm{21}$ ). In figuur 8 worden deze waarden weergegeven samen met de berekende waarden uit de ClGR-formule en de polynome regressielijn door de 'gemeten' waarden. Uit deze figuur blijkt dat er een groot verschil is tussen de regressiecurve van de eigen data en de CIGR curve. Dit wordt voor een deel veroorzaakt door de verdamping vanuit het strooisel, dat wordt meegenomen in de CIGR formule en voor een ander deel door het feit dat de groeifase (dagnummer) geen variabele is in de CIGR formule, waardoor er aan het begin van de groeiperiode een te lage $\mathrm{fQS}_{\mathrm{S}}$ lijkt te worden berekend als gevolg van een te hoge $T_{i}$ correctie. 


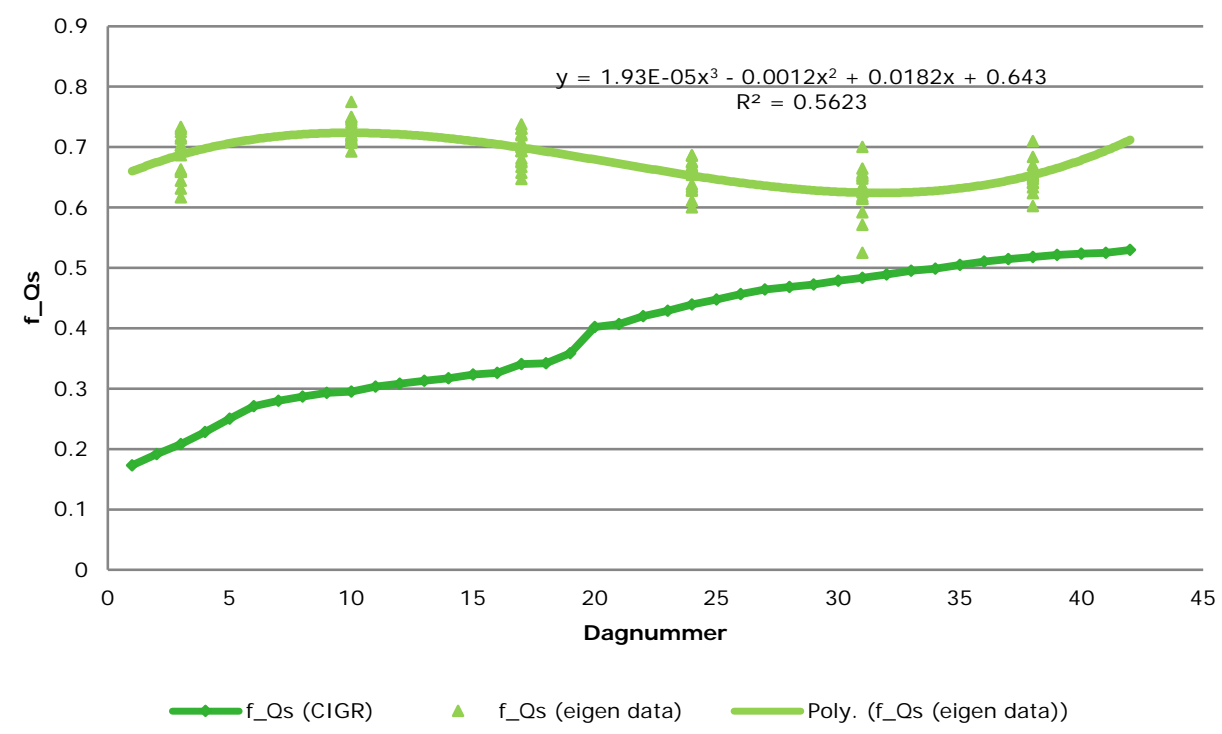

Figur 8 Het aandeel sensibele warmteafgifte in de totale warmteafgifte $\left(f_{Q s}\right)$ bepaald uit eigen data met een polynome regressielijn en berekend met de CIGR-formule

De waterverdamping kan nu worden berekend door QI te delen door de verdampingswarmte van water, die als volgt wordt berekend:

$c_{L}=2,497-0,0020 \cdot T_{b}$

Waarin: $\quad C_{L}$ is de verdampingswarmte van water bij $0^{\circ} \mathrm{C}(\mathrm{MJ} / \mathrm{kg})$

$\mathrm{T}_{\mathrm{b}}$ is de lichaamstemperatuur van het $\operatorname{dier}\left({ }^{\circ} \mathrm{C}\right)$

De uitscheiding van ds kan berekend worden door de onverteerde organische stof te sommeren met de hoeveelheid organische stof die uitgescheiden wordt via de urine en met het verschil tussen as-opname en as-aanzet.

$S_{D M}=$ Feed $_{O M} \cdot\left(1-v c_{O M}\right) \cdot F I+U_{O M}+F e e d_{A s h} \cdot F I-B_{A s h}$

Waarin: $S_{D M}$ is de uitgescheiden drogestof in de mest $(\mathrm{kg} / \mathrm{d})$

Feedom is het organische stof gehalte van het voer, input in model $(\mathrm{kg} / \mathrm{kg})$

vсom is de verteringscoëfficiënt van de organische stof, input in model $(\mathrm{kg} / \mathrm{kg})$

$\mathrm{FI}$ is de voeropname, berekend met de Gompertz-curve $(\mathrm{kg} / \mathrm{d})$

Uom is de uitgescheiden organische stof in de urine $(\mathrm{kg} / \mathrm{d})$

FeedAsh is het gehalte aan as in het voer, input in model $(\mathrm{kg} / \mathrm{kg})$

BAsh is de as-aanzet, berekend in formule $16(\mathrm{~kg} / \mathrm{d})$

Het gehalte aan organische stof in het voer is gelijk aan de som van de gehalten aan ruw eiwit, ruw vet, ruwe celstof en overige koolhydraten. De verteringscoëfficiënt van de organische stof kan worden berekend uit de verteerbaarheden van de hiervoor genoemde componenten. De uitgescheiden hoeveelheid organische stof met de urine wordt gelijk verondersteld aan de urinezuuruitscheiding:

$U_{O M}=\frac{168}{56} \cdot U_{U A N}$

Waarin: Uom is de uitgescheiden organische stof in urine $(\mathrm{kg} / \mathrm{d})$

UuAN is hoeveelheid uitgescheiden urinezuur-stikstof $(\mathrm{kg} / \mathrm{d})$

$168 / 56$ is de omrekening van $N$ naar urinezuur

De hoeveelheid uitgescheiden urinezuur- $\mathrm{N}$ kan berekend worden door de aangezette $\mathrm{N}$ af te trekken van de verteerde N. Hierbij wordt uitgegaan van de eiwitverteerbaarheid (input in model) en de eiwitaanzet (berekend). Voor de omrekening van eiwit naar $\mathrm{N}$ wordt de factor 6,25 gebruikt. Een klein deel van de $\mathrm{N}$ in de urine wordt uitgescheiden als ammonium (NH4-N). Ook in de feces is een klein deel van de uitgescheiden $\mathrm{N}$ aanwezig in de vorm van NH4- $\mathrm{N}$. Het model veronderstelt dat het percentage $\mathrm{N}$ in de vorm van $\mathrm{NH} 4-\mathrm{N}$ voor urine en feces gelijk is. Dit percentage is gekalibreerd met behulp van eigen data in ronde 4. De beste fit werd verkregen bij een percentage van $6 \%$. De totale hoeveelheid uitgescheiden $\mathrm{N}$ wordt berekend door de $\mathrm{N}$-aanzet af te trekken van de $\mathrm{N}$-opname. Ook de hoeveelheden uitgescheiden as, $\mathrm{P}$ en $\mathrm{K}$ worden op deze manier berekend. De P-aanzet is volgens forfaitaire 
gehalten (tabel 7 mineralenboekhouding) gelijk aan 0,00441 kg P/kg groei. De K-aanzet is gekalibreerd op eigen data en gelijk aan $0,00287 \mathrm{~kg} \mathrm{~K} / \mathrm{kg}$ groei. De totale uitscheiding van (verse) mest wordt berekend door de uitscheiding van water $\left(\mathrm{S}_{w}\right)$ en drogestof $\left(\mathrm{S}_{\mathrm{DM}}\right)$ bij elkaar op te tellen.

Op basis van de formules beschreven in paragrafen 4.1 en 4.2 kunnen de uitgescheiden hoeveelheden mest, ds, as, $\mathrm{N}$, P en K worden berekend. In figuur 9 worden de gemeten en de berekende waarden voor ronde 4 (alleen in deze ronde is de mestproductie gemeten door toevoeging van titaniumoxide aan het voer, zie par. 2.2.3) met elkaar vergeleken in $\mathrm{Y}=\mathrm{X}$ figuren. Voor $\mathrm{P}$ hebben we geen meetgegevens en deze is daarom niet opgenomen in figuur 9 . Uit de regressie-analyses blijkt dat de $R^{2}$ van de regressielijnen varieert van 0,93 tot 0,98 . De laagste $R^{2}$-waarden zijn gevonden voor Ntot en $\mathrm{NH} 4-\mathrm{N}\left(R^{2}=0,93\right)$. Voor alle variabelen was de constante in de regressielijn niet significant verschillend van 0 . De regressiecoëfficiënt was significant $(\mathrm{P}<0,05)$ verschillend van 1 voor as, Ntot en $\mathrm{NH} 4-\mathrm{N}$. Opvallend is dat alle regressiecoëfficiënten, behalve $\mathrm{K}$, lager zijn dan 1 . Dit wordt vooral veroorzaakt doordat een aantal hoge waarden, met een hoge hefboomwerking, onder de $Y=X$ lijn liggen. Bij normale regressie hebben deze hoge waarden een relatief grote invloed op de regressielijn. In het rekenmodel zijn de parameters bepaald met behulp van de kleinste kwadraten methode op basis van relatieve verschillen. Hierdoor hebben lage waarden een even groot effect op de regressielijn dan hoge waarden.
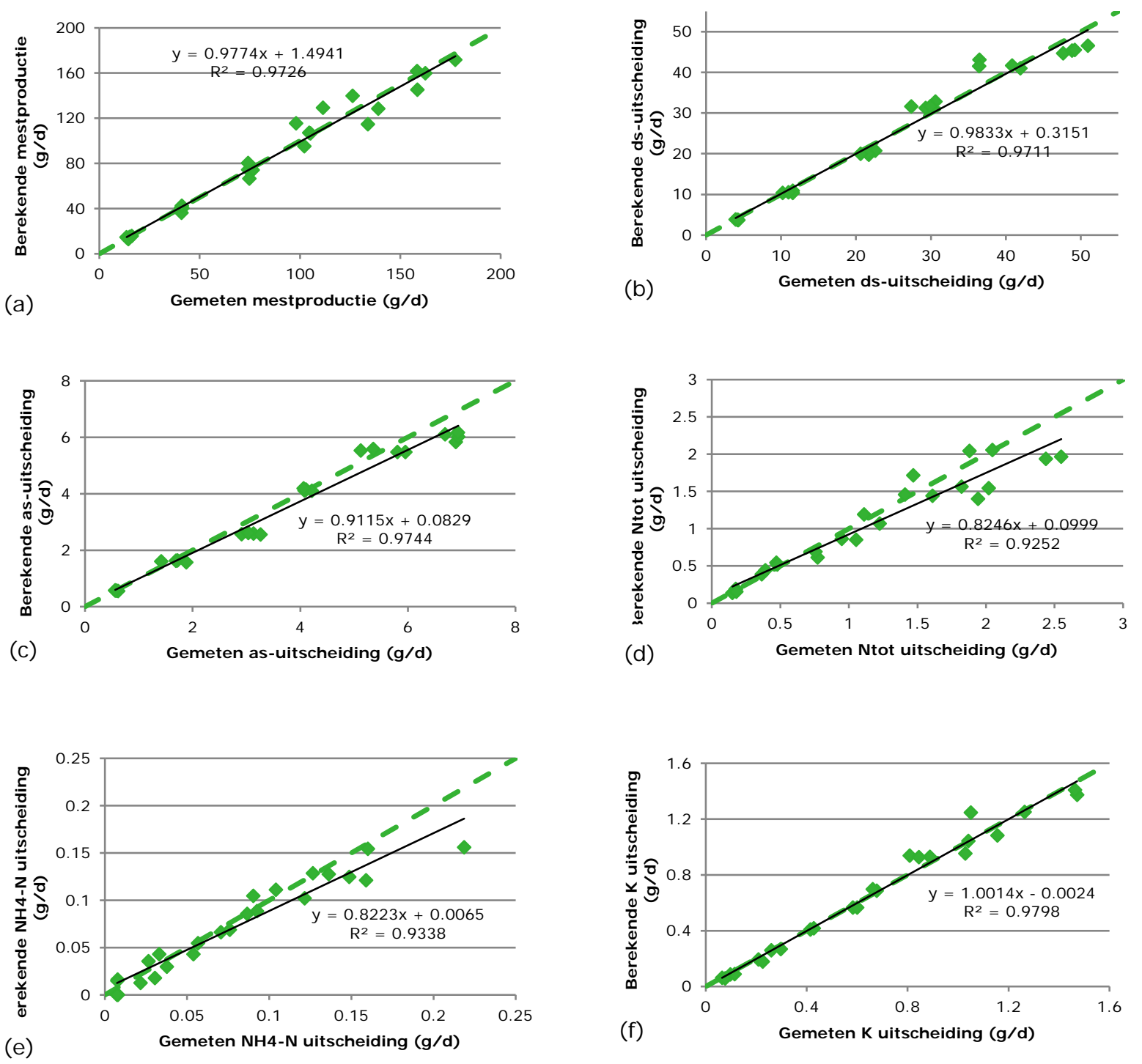

Figur 9 Vergelijking tussen berekende $(Y)$ en gemeten $(X)$ waarden in ronde 4 voor uitgescheiden hoeveelheden mest (a), ds (b), as (c), Ntot (d), NH4-N (e) en $K$ ( $f$ ) (allen in g/d per vleeskuiken). Elk punt is het gemiddelde van 4 hokken met dezelfde behandeling op een bepaalde meetdag. De dikke groen gestippelde lijn is de $Y=X$ lijn en de dunne zwarte lijn is de lineaire regressie van berekende waarden op gemeten waarden. De formule die bij de zwarte lijn hoort is steeds in de figuur gegeven. 
In figuur 10 wordt het gemiddeld gemeten (alleen ronde 4) en berekend (alle ronden) verloop gedurende de groeiperiode getoond. Hieruit blijkt dat het gemiddelde verloop van de berekende hoeveelheid uitgescheiden mest in ronde 4 goed overeen komt met de gemeten waarden. Hetzelfde geldt, in iets mindere mate, ook voor de verschillende uitgescheiden componenten. Op dag 11 en 33 zijn knikken te zien in de verschillende curves. Deze zijn het gevolg van de voerovergangen op die dagen. Deze overgangen zijn niet goed zichtbaar in de gemeten waarden.

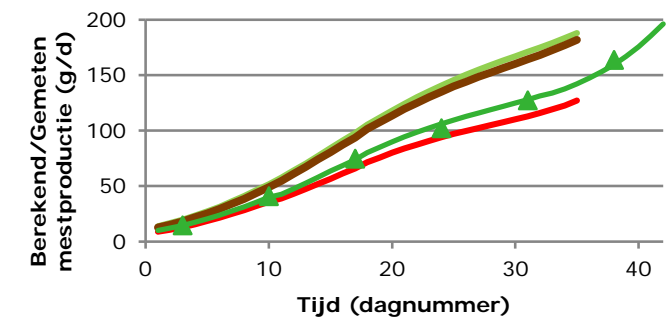

(a)
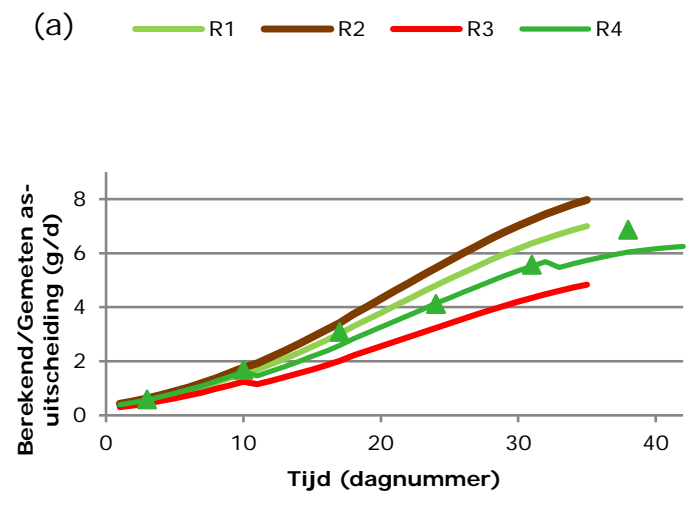

(c)
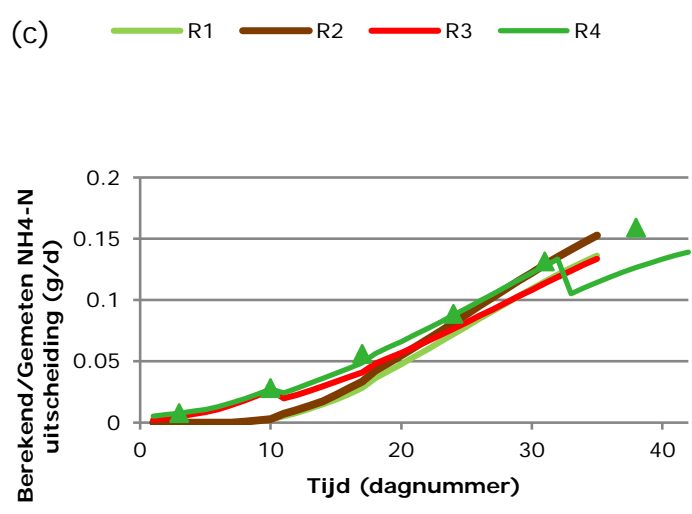

(e)

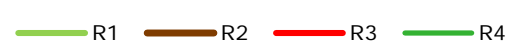

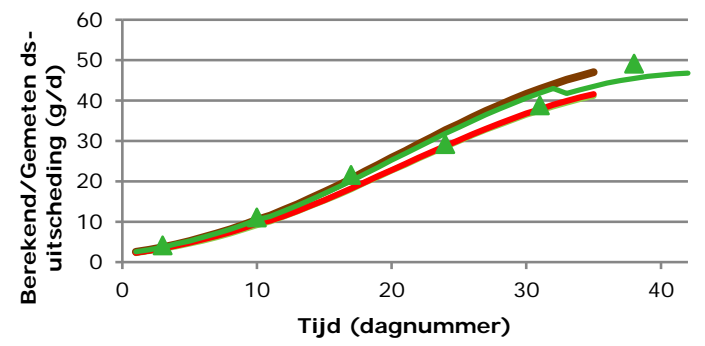

(b) R3 R4

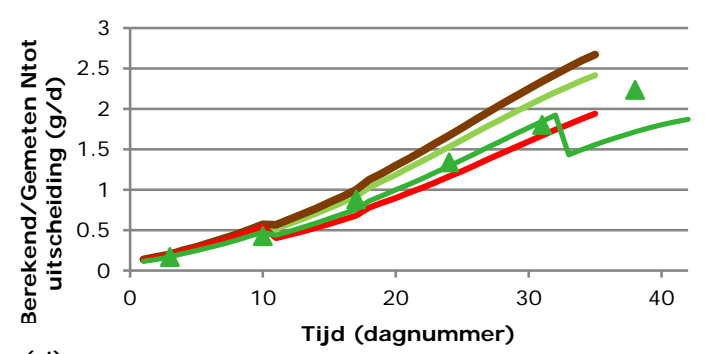

(d)
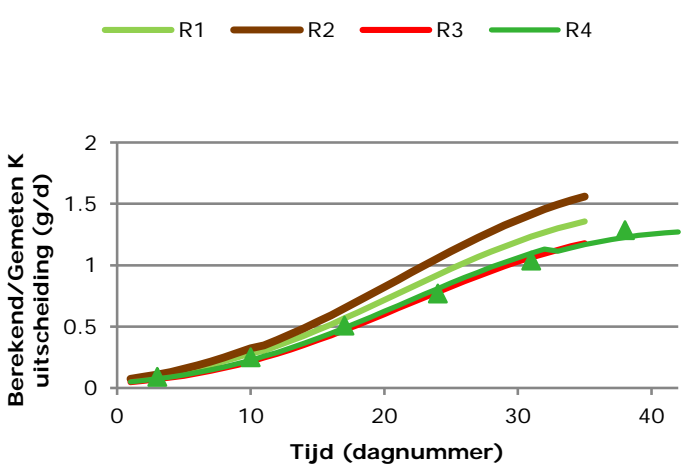

(f)

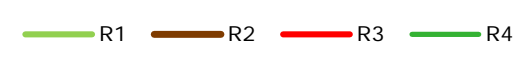

Figuur 10 Gemeten (punt; alleen ronde 4) en berekend (lijn) verloop van de uitgescheiden hoeveelheid mest (a), ds (b), as (c), Ntot (d), NH4-N (e) en K (f) ( $g / d$ per vleeskuiken) in de verschillende ronden ( $\mathrm{R} 1 \mathrm{t} / \mathrm{m} \mathrm{R} 4)$. Elk punt is het gemiddelde van 16 hokken.

In figuren 11 en 12 worden de $\mathrm{Y}=\mathrm{X}$ grafieken en het verloop tijdens de ronde gegeven voor de gehalten in de mest van ds, as, Ntot, NH4-N en K. Uit figuur 11 blijkt dat er grote variaties zijn tussen berekende en gemeten waarden. Vooral het ds-gehalte wijkt in ronde 3 in een aantal gevallen sterk af van de $Y=X$ lijn. Het is moeilijk aan te geven of de verschillen worden veroorzaakt door meetfouten of dat deze verschillen worden veroorzaakt door een foute inschatting door het model. Aangezien de berekende uitgescheiden hoeveelheden van de verschillende componenten goed overeenkomen met de gemeten hoeveelheden, lijkt de waterbalans een belangrijke bron van variatie te zijn. De waterbalans bepaald immers voor een belangrijk deel de berekende mestproductie.

In het verloop gedurende de groeiperiode (figuur 12) valt op dat voor de berekende waarden de voerovergangen heel goed te zien zijn in de berekende samenstelling van de feces, terwijl dit in de gemeten waarden vrijwel niet is terug te vinden. 


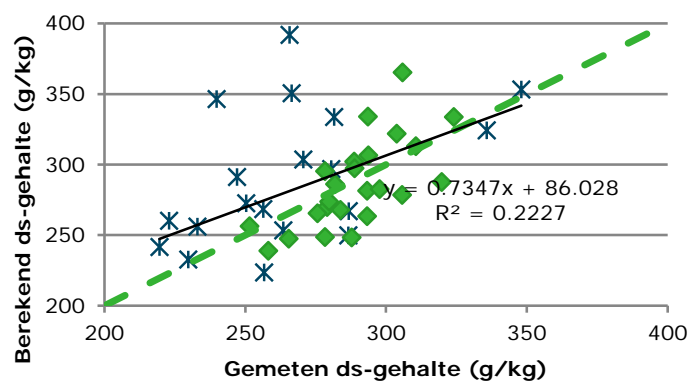

(a)

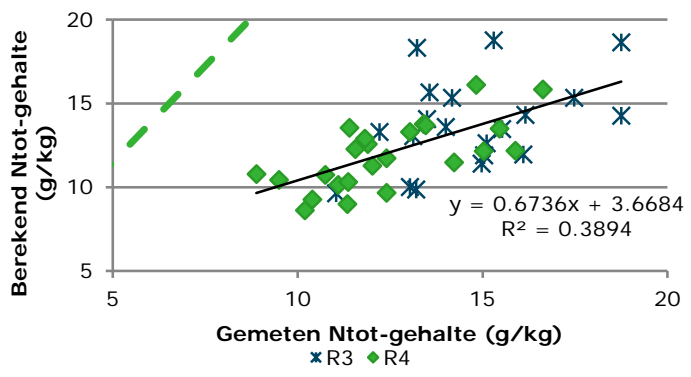

(c)

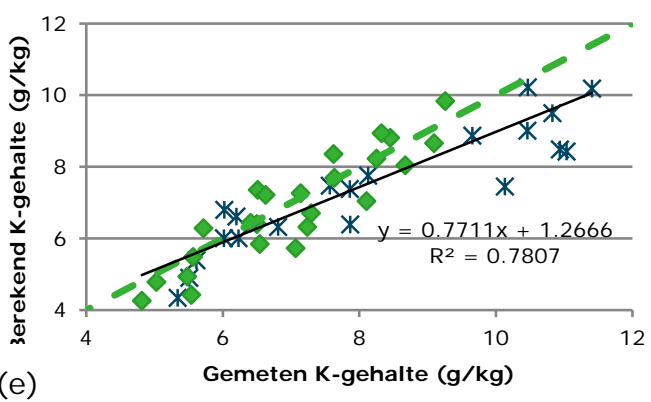

x R3 $\bullet \mathrm{R} 4$

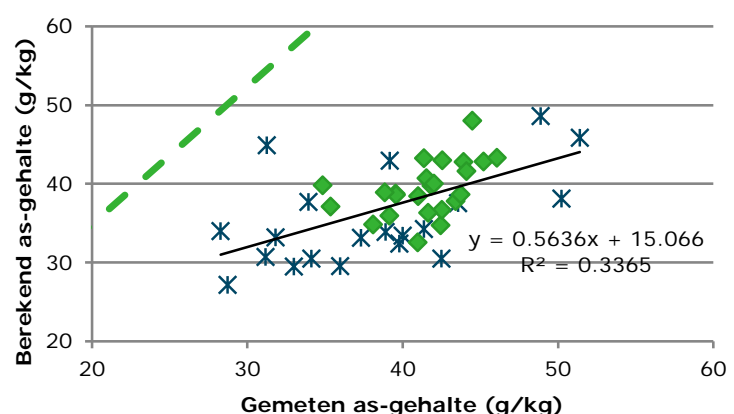

(b)

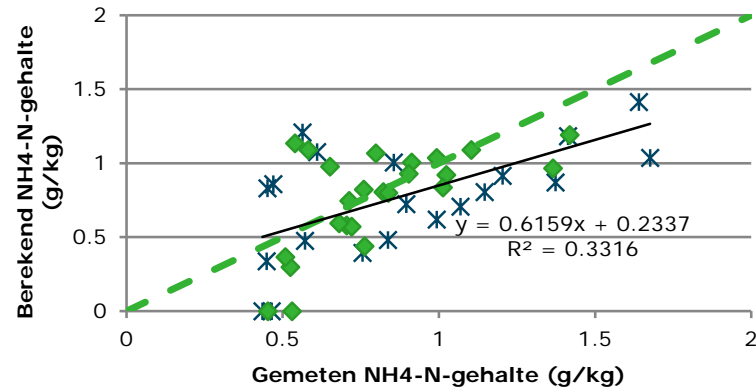

(d)

*R3 $\bullet$ R4

Figuur 11 Vergelijking tussen berekende $(Y)$ en gemeten $(X)$ waarden voor de gehalten in de uitgescheiden mest van ds (a), as (b), Ntot (c), NH4-N (d) en K (e) in $\mathrm{g} / \mathrm{kg}$ in ronden 3 en 4 (alleen in R3 en R4 is de mest-samenstelling bepaald). Elk punt is het gemiddelde van 4 hokken met dezelfde behandeling. De dikke groen gestippelde lijn is de $Y=X$ lijn en de dunne zwarte lijn is de lineaire regressie van berekende waarden op gemeten waarden. De formule die bij de zwarte lijn hoort is steeds in de figuur gegeven. 


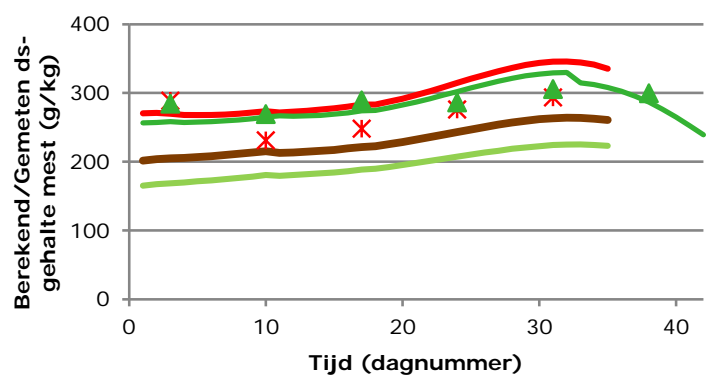

(a)

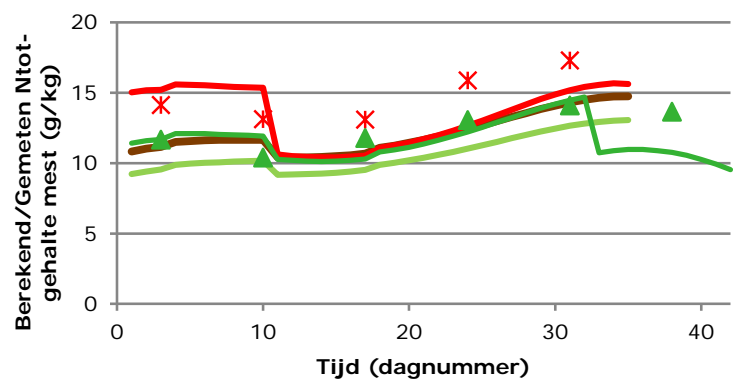

(c)
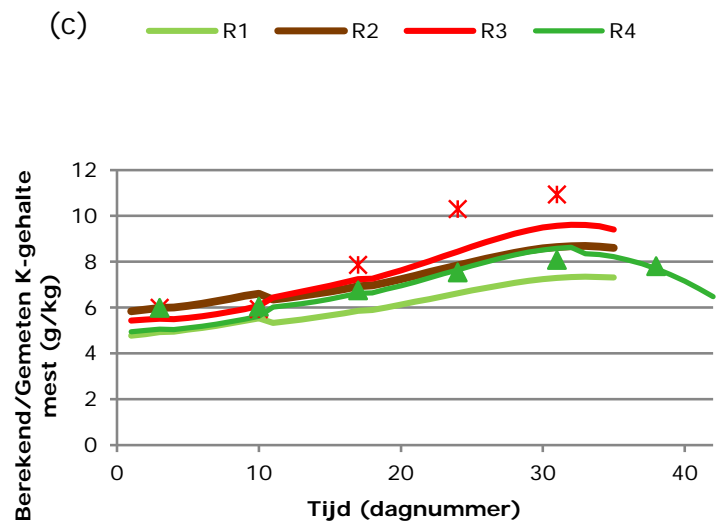

(e)

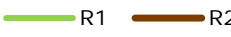

$3 \longrightarrow \mathrm{R} 4$

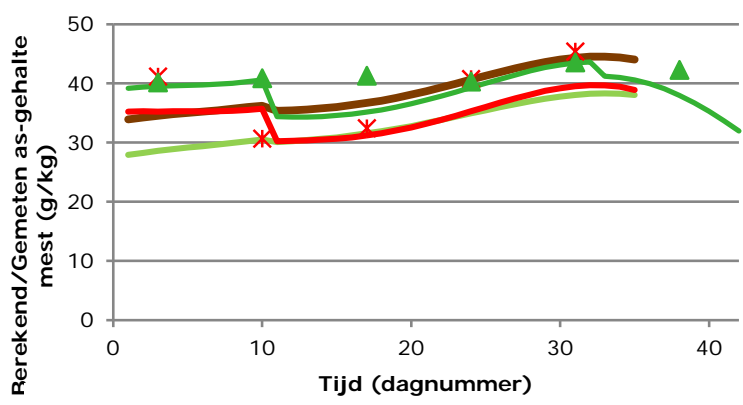

(b)

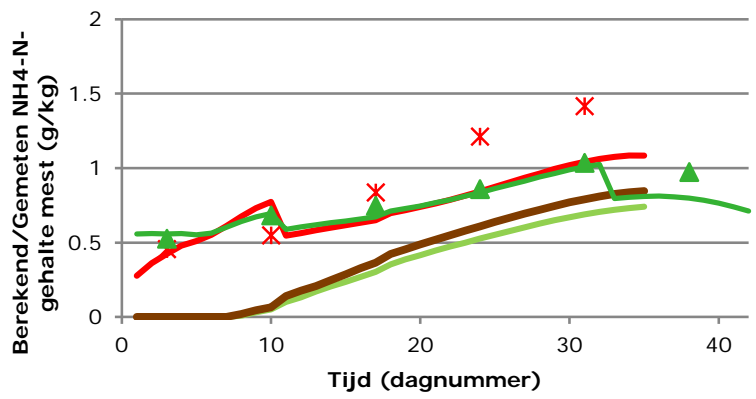

(d)

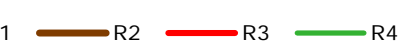

Figuur 12 Gemeten (punt; alleen R3 en R4) en berekend (lijn) verloop van de gehalten in de uitgescheiden mest van ds (a), as (b), Ntot (c), NH4-N (d) en K (e) (g/ kg) in de verschillende ronden (R1 t/m R4). Elk punt is het gemiddelde van 16 hokken. 


\subsection{Processen in het strooisel}

Het hok begint met schoon strooiselmateriaal, in dit onderzoek houtkrullen. Hieraan wordt de dagelijkse mestproductie van de vleeskuikens aan toegevoegd. Eventueel wordt er nog enig strooisel toegevoegd tijdens de groeiperiode als het strooisel te nat wordt. In de praktijk wordt dit laatste echter vrijwel niet gedaan. Vanuit het strooisel verdampt water en kunnen gassen emitteren. In het strooisel kunnen ook afbraakprocessen plaatsvinden waarbij organische stof wordt omgezet naar $\mathrm{CO}_{2}$ en water. De hoeveelheid strooisel(mest) per vleeskuiken op dag $t$ kan met de volgende formule worden beschreven:

$\operatorname{Litter}_{A_{-} t}=\sum_{0}^{t}\left(\right.$ Bedding $_{t}+S_{A_{-} t}-$ Litter $\left._{\text {Evap }_{-} t}-\left(1-f_{M W}\right) \cdot k_{O M_{-} t} \cdot S_{O M_{-} t}\right)$

Waarin: Litter A_t $_{-}$is de hoeveelheid strooisel(mest) op dag $\mathrm{t}(\mathrm{kg})$

Beddingt is de hoeveelheid toegevoegd strooisel op dag $t$ (vooral strooisel dat bij de start $(t=0)$ is aangebracht in de stal; alleen bij zeer nat strooisel, zoals in ronden 1 en 2, is tijdens de ronde strooisel toegevoegd $(\mathrm{kg})$

$\mathrm{S}_{\mathrm{A}_{\mathrm{L}} \mathrm{t}}$ is de mestproductie op dag $\mathrm{t}(\mathrm{kg})$

Litter $_{\text {Evap }} \mathrm{t}$ is de waterverdamping uit het strooisel op dag $\mathrm{t}(\mathrm{kg} / \mathrm{d})$

$f_{M W}$ is de hoeveelheid water die gevormd wordt door de bacteriële omzetting van $1 \mathrm{~kg}$ organische stof, de rest vervluchtigt als $\mathrm{CO}_{2}(\mathrm{~kg} / \mathrm{kg})$

Kom_t $_{\mathrm{t}}$ is het deel van de organische stof in de uitgescheiden mest dat omgezet wordt door bacteriën op dag $\mathrm{t}$ $(\mathrm{kg} / \mathrm{kg})$

Som_t is de totale hoeveelheid organische mest die uitgescheiden is door de vleeskuikens op dag $\mathrm{t}(\mathrm{kg})$

De verwachting is dat de microbiële omzetting in het strooisel relatief gering is, daarom wordt dit (voorlopig) verwaarloosd. De hoeveelheid verstrekt strooisel is input in het model. De totale mestproductie kan berekend worden uit de informatie in paragraaf 3.2. De verdamping uit het strooisel is gerelateerd aan het dampspanningsverschil tussen strooisel en lucht en is evenredig met het verdampend oppervlak. Deze verdamping kan als volgt worden berekend:

$\operatorname{evap}_{\text {litter }}=k_{-}$evap $\cdot\left(p_{\text {litter }}-p_{\text {air }}\right) \cdot A_{\text {litter }}$

Waarin: evaplitter is de waterverdamping uit het strooisel $(\mathrm{kg} / \mathrm{d})$

k_evap is de verdampingscoëfficiënt $\left(\mathrm{kg} /\left(\mathrm{m}^{2} \cdot \mathrm{kPa} \cdot \mathrm{d}\right)\right)$

( litter - pair) is het dampspanningsverschil op de grenslaag tussen strooisel en lucht ( $\mathrm{KPa}$ )

Alitter is het (verdampend) strooiseloppervlak $\left(\mathrm{m}^{2}\right)$

Hierbij wordt verondersteld dat de relatieve luchtvochtigheid van het verdampend oppervlak in het strooisel $100 \%$ is (het effect van ds-gehalte van het strooisel is verwerkt in $k_{\text {Evap, }}$ zie formule 30 ). De temperatuur van het oppervlak van het strooisel is via regressie op gemeten waarden bepaald.

Aangezien we voor de eerste 2 weken geen meetdata hebben van de oppervlaktetemperatuur en we voor die periode nog weinig warmteproductie in het strooisel verwachten wordt de oppervlaktetemperatuur voor deze periode gelijk gesteld aan de staltemperatuur. Hierna kan deze temperatuur worden beschreven met een kwadratische functie op dagnummer (dagen na start groeiperiode). Met deze functie kon $72 \%$ van de variatie in oppervlaktetemperatuur van ronde 4 worden verklaard. De constante en de regressiecoëfficiënten zijn: a T_surface $_{-}=33,438$ (s.e. 0,139 ), b1 $1_{T_{-} \text {surface }}$ (lineair) $=-0,4909$ (s.e. 0,0189), $b 2_{T_{-} \text {surface }}$ (quadratisch) $=0,009546$ (s.e. 0,000459).

De verdampingscoëfficiënt kevap kan berekend worden met behulp van de volgende aangepaste formule van Beeking et al. (1994):

$k_{\text {Evap }}=a_{k_{\text {Evap }}}+b_{k_{\text {Evap }}} \cdot \sqrt{v} \cdot\left(\frac{\left(\text { Litter }_{W \%}-16\right)}{0,03}+21\right)$

Waarin: $k_{\text {Evap }}$ is de verdampingscoëfficiënt $\left(\mathrm{kg} /\left(\mathrm{m}^{2} . \mathrm{kPa} . \mathrm{d}\right)\right)$

$a_{k_{-}}$Evap is een constante

$b_{k_{-} E v a p}$ is een regressiecoëfficiënt

$v$ is de luchtsnelheid over het verdampend oppervlak $(\mathrm{m} / \mathrm{s})$

Litterw\% is het watergehalte van het strooisel in percentage (\%)

$a_{k_{-} E v a p}$ en $b_{k_{-} E v a p}$ zijn berekend in het model via kalibratie op het watergehalte van het strooisel van alle ronden. Voor $a_{k_{-} \text {Evap }}=0,2513$ en $b_{k_{-} \text {Evap }}=0,0001312$ werd de beste fit verkregen. 
De luchtsnelheid wordt berekend met behulp van de volgende relatie van Aarnink en Elzing (1998) voor de luchtsnelheid op vloerniveau afhankelijk van het ventilatiedebiet per $\mathrm{m}^{2}$ staloppervlak:

$v=0,106+4,62 \cdot$ vent $_{m^{2}}$

Waarin: $\quad v$ is de luchtsnelheid over het verdampend oppervlak $(\mathrm{m} / \mathrm{s})$

vent $_{\mathrm{m} 2}$ is het ventilatiedebiet per $\mathrm{m}^{2}$ staloppervlak $\left(\mathrm{m}^{3} / \mathrm{s}\right.$ per $\mathrm{m}^{2}$ staloppervlak)

De $\mathrm{pH}$ van het strooisel is bepaald via regressie van gemeten potentiele invloedvariabelen op de gemeten $\mathrm{pH}$ :

Litter $_{p H}=a_{p H}+b 1_{p H} \cdot$ Litter $_{N H 4 N}+b 2_{p H} \cdot$ Feed $_{d E B}+b 3_{p H} \cdot$ Day

Waarin: Litter $\mathrm{pH}$ is de $\mathrm{pH}$ van de bulk strooisel (-)

$a_{p H}$ is een constante, $b 1_{p H}, b 2_{p H}$ en $b 3{ }_{p H}$ zijn regressiecoëfficiënten

Litter $_{\mathrm{NH} 4 \mathrm{~N}}$ is het ammoniumgehalte van het strooisel $(\mathrm{kg} / \mathrm{kg})$

Feed $_{\mathrm{dEB}}$ is het dEB (dietary electrolyte balance) van het voer $(\mathrm{mEq} / \mathrm{kg}$ )

Day is dagen na opzet vleeskuikens (dagnummer)

De beste fit voor $\mathrm{pH}$-data van ronde 4 werd verkregen met de volgende waarden: $\mathrm{apH}_{\mathrm{pH}}=8,453$ (s.e. 0,568), b1 = 575 (s.e. 91), b2 =0,00590 (s.e. 0,00231), b3 =-0,1413 (s.e. 0,0125). Met deze regressielijn kon $65 \%$ van de variatie in de $\mathrm{pH}$ in ronde 4 worden verklaard.

Uit de statistische analyse van de gemeten resultaten blijkt dat de rulheid van het strooisel een belangrijke invloedfactor is op de ammoniakemissie. Analyse laat zien dat de rulheid vooral wordt beïnvloed door het ds-gehalte van het strooisel (gemeten waarde) en van het verschil tussen de dagelijkse hoeveelheid water dat toegevoegd wordt aan het strooisel via de mest en de hoeveelheid water dat verdampt uit het strooisel (berekende waarde):

Litter $_{\text {Loos_t }}=a_{\text {Loos }}+b 1_{\text {Loos }} \cdot$ Litter $_{\text {DM }}+b 2_{\text {Loos }} \cdot$ Water $_{\text {Added_t }}$

(33)

Waarin: Litter Loos_t $_{\text {t }}$ is de rulheid van het strooisel op dag t (zie par. 2.3.1 voor een beschrijving van de kwalitatieve rulheidsscore) (-)

$a_{\text {Loos, }}$ b1 $1_{\text {Loos }}$ en b2 Loos $z i j n$ respectievelijk de constante en de regressiecoëfficiënten

Litter ${ }_{D M}$ is het ds-gehalte van het strooisel $(\mathrm{kg} / \mathrm{kg})$

Water $_{\text {Added_t }}$ is de hoeveelheid water die toegevoegd is aan het strooisel op dag $\mathrm{t}$, berekend als het verschil tussen het toegevoegde water via de mest en de waterverdamping uit het strooisel $(\mathrm{kg} / \mathrm{d})$

Aangezien de rulheid van het strooisel sterk varieerde tussen de verschillende ronden, is bovenstaande regressielijn gefit met data van alle ronden. De beste fit werd verkregen met de volgende waarden: $a_{\text {Rulheid }}=8,453$ (s.e. 0,568), b1 = 575 (s.e. 91), b2 =0,00590 (s.e. 0,00231), b3 $=-0,1413$ (s.e. 0,0125$)$.

De temperatuur van het emitterend oppervlak is gedurende de eerste twee weken niet gemeten. Aangezien er gedurende die periode nog weinig warmte wordt gevormd in het strooisel, veronderstellen we dat deze gelijk is aan de staltemperatuur, in ons experiment gemeten in de uitgaande lucht. Vanaf de derde week ging de temperatuur van het strooiseloppervlak eerst naar een minimum en nam vervolgens weer toe. Deze toename kan enerzijds worden veroorzaakt door opwarming van het strooisel door de vleeskuikens en anderzijds door warmteproductie als gevolg van composteringsprocessen in het strooisel. De kwadratisch curve, waarmee (slechts) $43 \%$ van de variatie in gemeten oppervlaktetemperatuur van ronde 4 vanaf dag 14 kon worden verklaard, ziet er als volgt uit:

$T_{\text {surface }}=44,2-1,19 \cdot$ Day $+0,020 \cdot$ Day $^{2}$

Waarin: $\mathrm{T}_{\text {surface }}$ is de temperatuur van het emitterend oppervlak $\left({ }^{\circ} \mathrm{C}\right)$

Day is dagen na opzet vleeskuikens (dagnummer) 
In figuur 13 zijn de berekende waarden uitgezet tegen de gemeten waarden in $\mathrm{Y}=\mathrm{X}$ grafieken. Hieruit blijkt dat het ds-gehalte van het strooisel, over de gehele linie genomen, redelijk geschat wordt met het rekenmodel. Alhoewel er behoorlijke verschillen kunnen optreden tussen ronden (b.v. de verschillen tussen ronden 3 en 4 bij gemeten waarden tussen de 600 en $700 \mathrm{~g} / \mathrm{kg}$ ). Het as-gehalte laat grote verschillen tussen ronden zien, vooral tussen ronden 1 en 2 . Ntot fit redelijk bij lagere waarden maar wijkt af bij hogere waarden, waarbij de berekende waarden lager liggen dan de gemeten waarden. Opvallend is vooral de ruime systematische onderschatting van het Ntot-gehalte in ronde 3. Het $\mathrm{NH} 4 \mathrm{~N}$-gehalte wordt systematisch over de gehele range onderschat met het rekenmodel. Voor het K-gehalte geldt hetzelfde als voor Ntot, een duidelijke onderschatting door het rekenmodel ten opzichte van de berekende waarden. De pH van het strooisel wordt enigszins onderschat door het rekenmodel. Dit wordt waarschijnlijk vooral veroorzaakt door de onderschatting van het $\mathrm{NH} 4 \mathrm{~N}$-gehalte van het strooisel. De rulheid van het strooisel wordt gemiddeld goed geschat, maar wordt bij lage waarden enigszins overschat en bij hoge waarden enigszins onderschat. De temperatuur van het (emitterend) oppervlak van het strooisel blijkt moeilijk te schatten. Ondanks dat de regressielijn is gefit op data van ronde 4 , is de schatting van de gemeten waarden met het model zeer mager. De gemeten waarden van ronde 3 liggen allemaal boven de $Y=X$ lijn. Dit betekent dat de gemeten waarden systematisch lager waren dan de berekende waarden. De absolute verschillen tussen berekende en gemeten temperaturen vallen echter mee $\left(<3^{\circ} \mathrm{C}\right)$. 


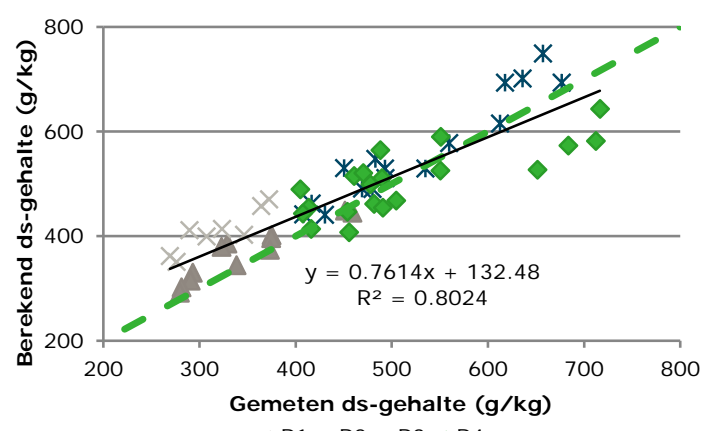

(a)

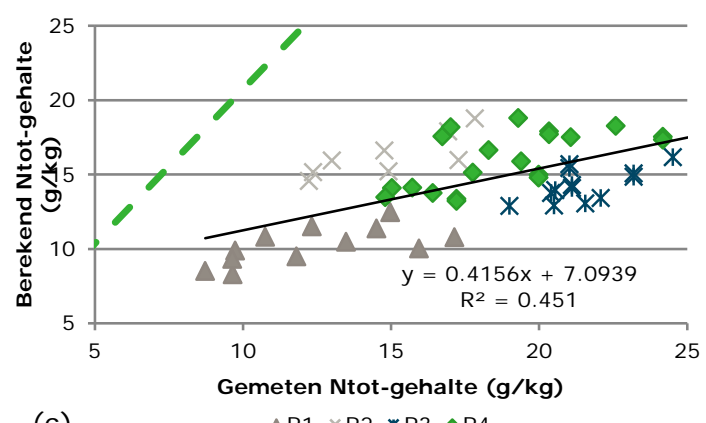

(c)

$\triangle \mathrm{R} 1 \times \mathrm{R} 2 \times \mathrm{R} 3 \bullet \mathrm{R} 4$

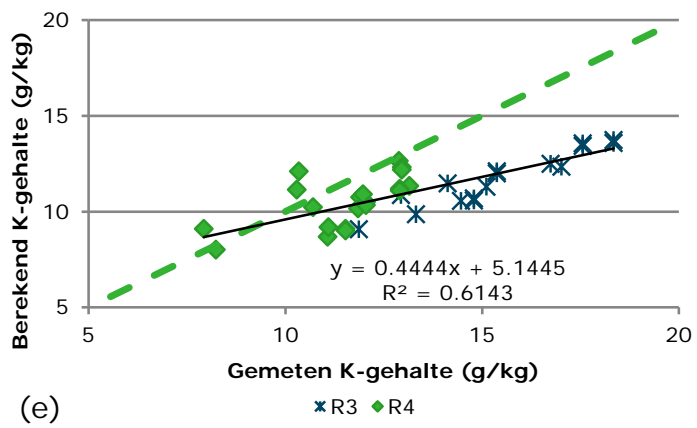

(e)

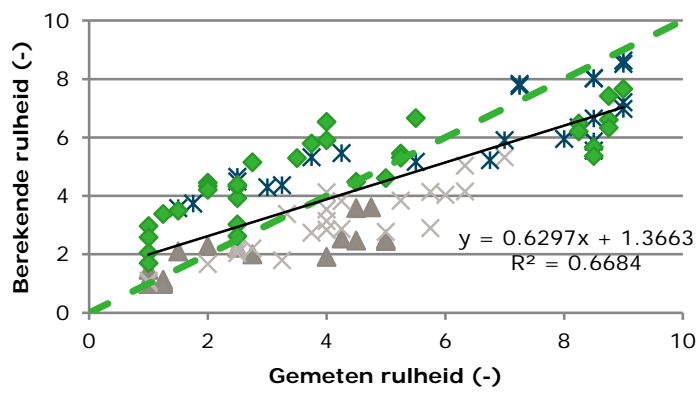

(g)

$\triangle R 1 \times R 2 \times R 3 \bullet R 4$

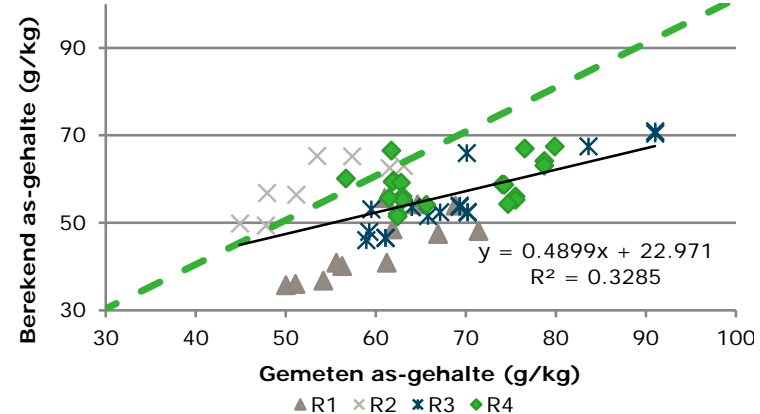

(b)

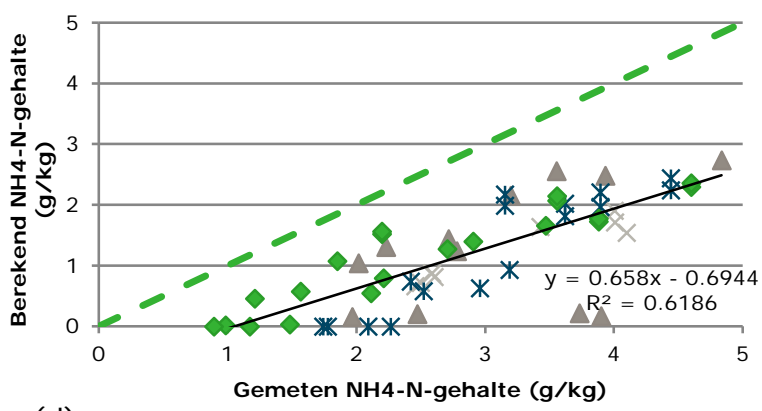

(d)

$\triangle \mathrm{R} 1 \times \mathrm{R} 2 \times \mathrm{R} 3 \bullet \mathrm{R} 4$
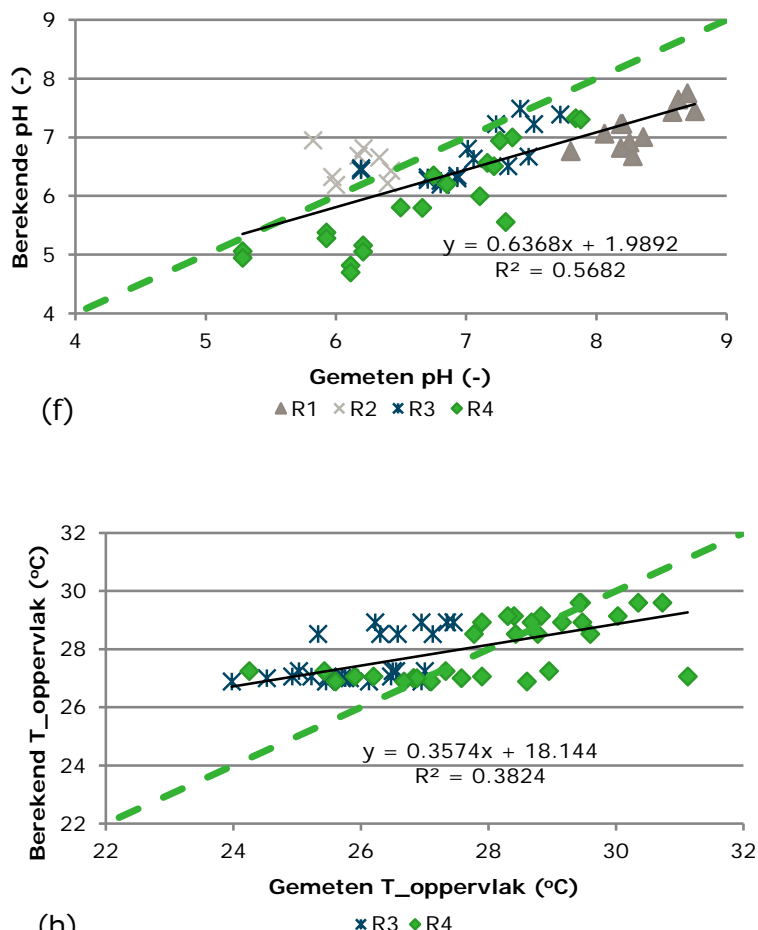

(h)

Figuur 13 Vergelijking tussen berekende $(Y)$ en gemeten $(X)$ waarden voor de gehalten in het strooisel van ds (a), as (b), Ntot (c), NH4-N (d), K (e) (allen in $\mathrm{g} / \mathrm{kg}$ ), $\mathrm{pH}$ (f) en rulheid (g) van het strooisel in de verschillende ronden (R1 t/m R4; $K$ is alleen in R3 en R4 bepaald). Elk punt is het gemiddelde van 4 hokken met dezelfde behandeling. De dikke groen gestippelde lijn is de $Y=X$ lijn en de dunne zwarte lijn is de lineaire regressie van berekende waarden op gemeten waarden. De formule die bij de zwarte lijn hoort is steeds in de figuur gegeven. Het K-gehalte en de oppervlakte temperatuur van het strooisel zijn alleen in ronde 3 en 4 gemeten. 


\subsection{Berekening van de ammoniakemissie}

De ammoniakemissie kan als volgt worden berekend (Aarnink \& Elzing, 1998):

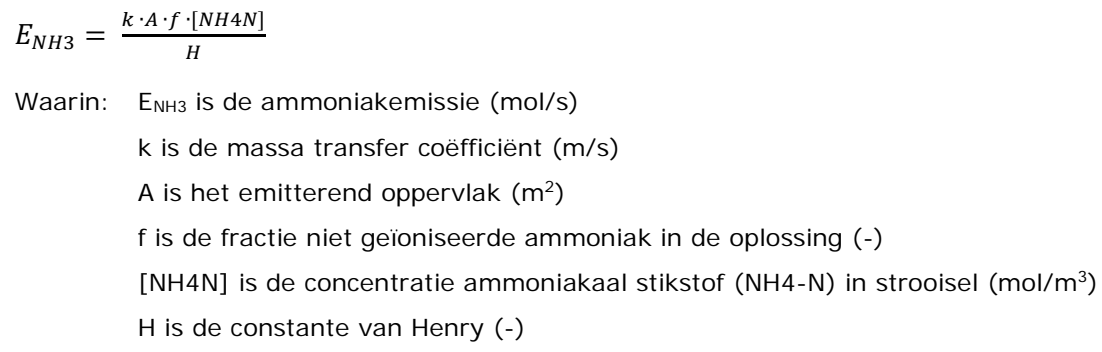

De ammoniakemissie wordt vervolgens omgerekend naar $\mathrm{g} / \mathrm{d}$ per vleeskuiken. Hierbij veronderstellen we een soortelijk gewicht van het strooisel van $600 \mathrm{~kg} / \mathrm{m}^{3}$. De massa transfer coëfficiënt $(k)$ is afhankelijk van de luchtsnelheid over en de temperatuur van het emitterende oppervlak.

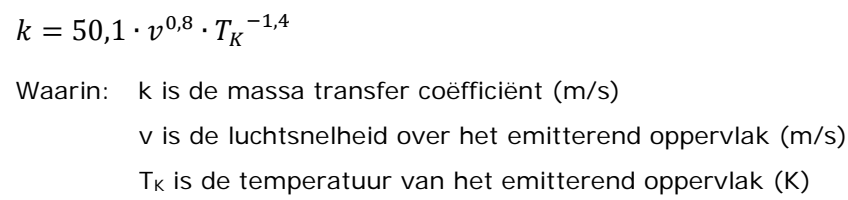

De emitterende oppervlakte $(A)$ wordt gelijk verondersteld aan het verdampend oppervlak zoals beschreven in de vorige paragraaf. De fractie niet geïoniseerde ammoniak in de oplossing (f) is afhankelijk van de $\mathrm{pH}$ ( Litter $_{\mathrm{pH}}$ ) en de temperatuur van het emitterend oppervlak ( $\left.\mathrm{T}_{\text {surface }}\right)$ en kan beschreven worden met de volgende formule (Groot Koerkamp \& Elzing, 1996):

$f=1 /\left(1+\exp \left(-2,303 *\left(\right.\right.\right.$ Litter $\left.\left.\left._{p H}-\left(8,65-\left(T_{\text {surface }}-20\right) * \log _{10}(1,074)\right)\right)\right)\right)$

Waarin: $f$ is de fractie niet geïoniseerde ammoniak in de oplossing (-)

Litter $_{\mathrm{pH}}$ is de $\mathrm{pH}$ van strooisel (-)

$\mathrm{T}_{\text {surface }}$ is de temperatuur van het emitterend oppervlak $\left({ }^{\circ} \mathrm{C}\right)$

De $\mathrm{pH}$ van het strooisel wordt berekend met formule 32. De temperatuur van het emitterend oppervlak wordt berekend met formule 34.

De constante van Henry is afhankelijk van de temperatuur van het emitterende oppervlak (Aarnink \& Elzing, 1998):

$H=1431 \cdot 1,053^{\left(20-T_{\text {surface }}\right)}$

Waarin: $\quad H$ is de constante van Henry (-)

$\mathrm{T}_{\text {surface }}$ is de temperatuur van het emitterend oppervlak $\left({ }^{\circ} \mathrm{C}\right)$

De NH4-N-concentratie in strooisel kan als volgt worden berekend:

$[N H 4 N]_{(t)}=\frac{\text { Litter }_{N H 4 N(t-1)}+S_{N H 4 N(t)}+f_{U A N} \cdot \text { Litter }_{U A N(t)}-E_{N H 3 N(t)}}{\text { Litter }_{A(t)} / \rho_{\text {Litter }}} \cdot \frac{1000}{14}$

Waarin: $[\mathrm{NH} 4 \mathrm{~N}]_{(\mathrm{t})}$ is de ammoniakaal- $\mathrm{N}(\mathrm{NH} 4-\mathrm{N})$ concentratie van strooisel op dag $\mathrm{t}\left(\mathrm{mol} / \mathrm{m}^{3}\right)$

Litter $_{\mathrm{NH} 4 \mathrm{~N}(\mathrm{t}-1)}$ is de hoeveelheid $\mathrm{NH} 4-\mathrm{N}$ in strooisel op dag t-1 $(\mathrm{kg})$

$\mathrm{S}_{\mathrm{NH} 4 \mathrm{~N}(\mathrm{t})}$ is de hoeveelheid $\mathrm{NH} 4-\mathrm{N}$ uitgescheiden in de verse mest op dag $\mathrm{t}(\mathrm{kg})$

$\mathrm{f}_{\text {UAN }}$ is de fractie van urinezuur- $\mathrm{N}$ die dagelijks wordt omgezet naar NH4-N (-)

Litteruan(t) is de hoeveelheid urinezuur- $\mathrm{N}$ in strooisel op dag $\mathrm{t}(\mathrm{kg})$

$E_{N H 3 N(t)}$ is de ammoniak- $N$ emissie uit strooisel op dag $t(\mathrm{~kg})$

Litter $_{A(t)}$ is de hoeveelheid strooisel(mest) op dag $\mathrm{t}(\mathrm{kg})$

$\rho_{\text {Litter }}$ is het soortelijk gewicht van strooisel $\left(\mathrm{kg} / \mathrm{m}^{3}\right)$

$1000 / 14$ is de conversiefactor van $\mathrm{kg} \mathrm{N}$ naar mol N 
De rulheid van het strooisel heeft invloed op de ammoniakemissie. Deze invloed kan op twee manieren worden verklaard:

1. Voor de omzetting van urinezuur naar ammoniak is zuurstof nodig. In nat strooisel kan weinig zuurstof toetreden waardoor deze omzetting veel trager verloopt.

2. Ruller strooisel heeft een groter contactoppervlak met de lucht dan nat strooisel. De ammoniakemissie is evenredig met het emitterend contactoppervlak met de lucht.

Om de ammoniakemissie te corrigeren voor de rulheid van het strooisel is de volgende empirische relatie ontwikkeld op basis van data van ronde 4 :

$f_{\text {Loos }}=\frac{0,8193\left(10-\text { Litter }_{\text {Loos }}\right)}{0,3209}$

Waarin: $f_{\text {Loos }}$ is de correctiefactor voor de ammoniakemissie voor de rulheid van het strooisel (-)

Litter Loos is de score voor rulheid van het strooisel, berekend met formule 33 (-)

Een factor die we niet kennen maar wel van belang is, is de snelheid van omzetting van urinezuur naar NH4-N. In formule 39 is dit weergegeven als een fractie van de totale hoeveelheid urinezuur- $\mathrm{N}$ die dagelijks wordt omgezet naar NH4-N (fUAN). We hebben twee scenario's doorgerekend, één scenario waarbij we fuan gelijk veronderstellen voor alle ronden en één scenario waarbij de urinezuuromzetting kan verschillen tussen ronden. Bij beide scenario's hebben we fuan gekalibreerd op gemeten data van zowel de NH4-N-concentratie als de ammoniakemissie. Voor de luchtsnelheid over het emitterend oppervlak zijn de luchtsnelheden genomen die ten tijde van de $\mathrm{NH}_{3}$-emissiemetingen werden opgelegd met behulp van de meetbox. De luchtsnelheid is daarbij berekend door het luchtdebiet (in $\mathrm{m}^{3} / \mathrm{s}$ ) te delen door het doorstroomoppervlak van de meetbox. Bij de kalibratie is de som van de kleinste kwadraten (zie formule 8 ) voor $\mathrm{NH} 4-\mathrm{N}$ en voor de $\mathrm{NH}_{3}$-emissie geminimaliseerd.

In figuur 14 zijn de resultaten van de modelberekeningen uitgezet tegen de gemeten waarden in $Y=X$ figuren. Voor figuren $14 \mathrm{a}$ en $\mathrm{b}$ is een vaste urinezuuromzetting per dag (fUAN) aangehouden in de verschillende ronden van 3,0\% per dag van de aanwezige urinezuur en in figuren $14 \mathrm{c}$ en $\mathrm{d}$ is deze bij de kalibratie variabel gemaakt. Uit deze figuren blijkt dat bij een vaste urinezuuromzetting de grote verschillen in ammoniakemissie tussen de verschillende ronden niet te verklaren zijn. Bij een variabele urinezuuromzetting zijn de verschillen tussen ronden 1, 2 en 4 redelijk te verklaren, maar zijn de hoge waarden die gemeten zijn in ronde 3 nog steeds niet te verklaren. 


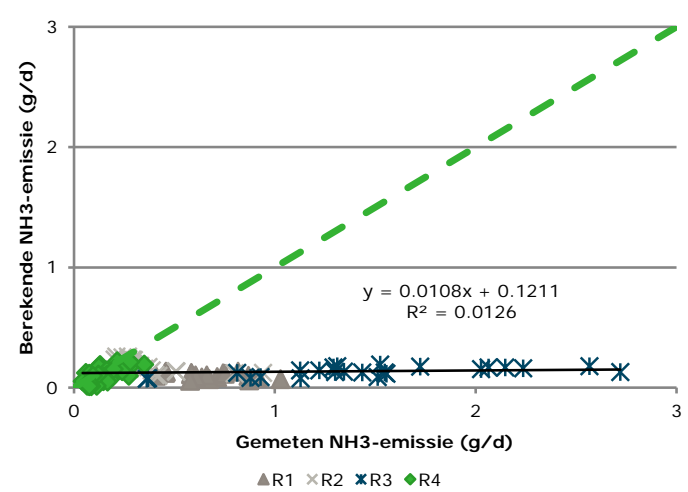

(a)

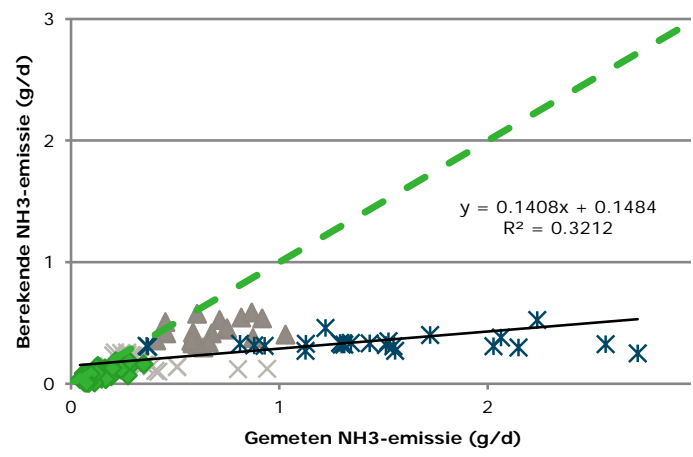

(c)

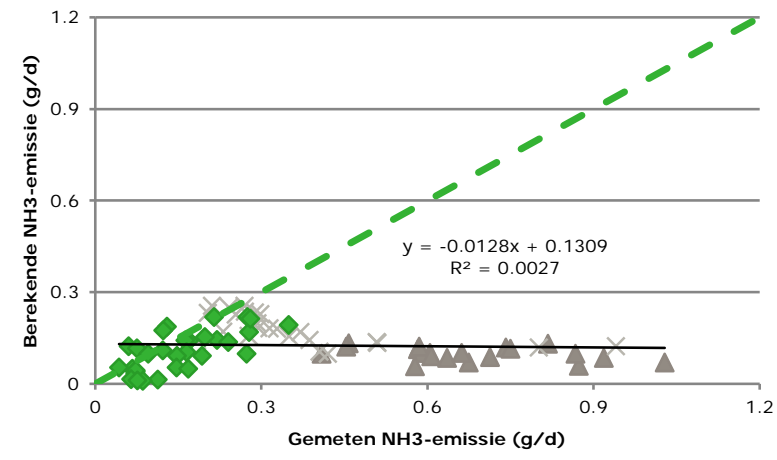

(b)

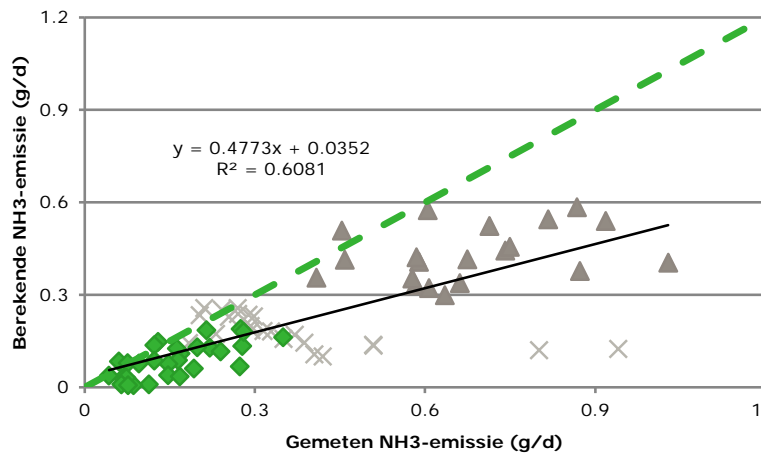

(d) $\triangle \mathrm{R} 1 \times \mathrm{R} 2 \bullet \mathrm{R} 4$

Figuur 14 Vergelijking tussen berekende $(Y)$ en gemeten $(X)$ waarden voor de ammoniakemissie uit het strooisel in $\mathrm{g} / \mathrm{d}$ per vleeskuiken; (a) bij een vaste omzetting van urinezuur van 3,0\% per dag voor R1 t/m R4; (b) gelijk aan a zonder R3; (c) bij een variabele omzetting van urinezuur van $15,8 \%$ voor R1, 3,0\% voor R2, 7,2\% voor R3 en 1,9\% voor R4; (d) gelijk aan c zonder R3. Elk punt is het gemiddelde van 4 hokken met dezelfde behandeling. De dikke groen gestippelde lijn is de $Y=X$ lijn en de dunne zwarte lijn is de lineaire regressie van berekende waarden op gemeten waarden. De formule die bij de zwarte lijn hoort is steeds in de figuur gegeven. 


\section{$5 \quad$ Algemene discussie}

Dit onderzoek had twee doelstellingen: 1 ) het bepalen van het effect van het ruw eiwit- en K-gehalte van het voer op de strooiselkwaliteit/-karakteristieken en de ammoniakemissie; 2) het ontwikkelen van een rekentool om het effect van voermaatregelen op de ammoniakemissie te kunnen voorspellen.

Uit dit onderzoek blijkt dat vooral het K-gehalte een zeer sterke invloed heeft op de strooiselkwaliteit, gekarakteriseerd door ds-gehalte en rulheid van het strooisel (zie tabel 16). Hogere K-gehalten in het voer zorgen voor natter en minder rul strooisel. Het gevolg hiervan is dat de mate van voorkomen en de ernst van voetzoollaesies en hakdermatitis toenemen (zie tabellen 10, 11 en 12). Deze problemen lijken ook de oorzaak te zijn van de lagere voeropname en lagere groei bij gebruik van voeders met relatief hoge gehalten aan kalium (De Jong et al, 2014). Er lijkt geen effect te zijn van het eiwitgehalte op de strooiselkwaliteit of op het voorkomen van voetzoollaesies en hakdermatitis. Wel was de voerconversie enigszins verslechterd bij het lagere eiwitniveau. Dit lijkt een rechtstreeks gevolg te zijn van het lagere eiwitgehalte in het voer, waardoor er toch een tekort lijkt te zijn van één of meerdere (essentiële) aminozuren (bijvoorbeeld glycine of serine), wat zich uit in een lagere groei. Opvallend genoeg heeft zowel het K-gehalte van het voer als het eiwitgehalte van het voer geen significant effect op de ammoniakemissie, wanneer deze gehalten als continue variabelen zijn opgenomen in een lineaire regressie. In een analyse waarbij verschillende strooiselkarakteristieken ( Ntot, NH4- N, pH, rulheid) en ventilatiedebiet zijn opgenomen in het model blijkt dat Ntot en NH4- $\mathrm{N}$ gehalten geen significant effect hebben op de ammoniakemissie (zie tabel 17). De pH en de rulheid van het strooisel en het ventilatiedebiet hebben daarentegen een sterk effect op de ammoniakemissie. Het effect van eiwitgehalte op de ammoniakemissie zou vooral via het Ntot en NH4-N gehalte van het strooisel moeten werken. Als deze variabelen geen significant effect blijken te hebben op de ammoniakemissie dan is daarmee ook verklaard waarom geen effect van eiwitgehalte kan worden aangetoond. Het K-gehalte heeft een sterk negatief effect op de rulheid van het strooisel. De rulheid van het strooisel is positief gerelateerd met de ammoniakemissie. Daarom zou een negatief verband tussen $\mathrm{K}$-gehalte van het voer en de ammoniakemissie verwacht mogen worden. Dit werd echter niet gevonden (zie tabel 16), waarschijnlijk vanwege het feit dat het K-gehalte tevens zorgt voor een scala aan andere effecten, waaronder de eerder genoemde verminderde productie.

De ontwikkelde rekentool is op dit moment nog vooral een onderzoekmodel en nog niet geschikt voor brede toepassing voor het doorrekenen van effecten. De huidige stand van het model is dat het gewichtsverloop van de vleeskuikens en de voer- en wateropname gedurende de groeiperiode goed voorspeld kunnen worden als het eindgewicht en de totale voer- en wateropname bekend zijn en als input in het model kunnen worden gebruikt. De uitgescheiden hoeveelheden van de verschillende componenten in de verse mest lijken ook goed voorspeld te kunnen worden, alhoewel dit nog niet getoetst is met een onafhankelijke dataset, maar alleen nog met de gegevens uit ronde 4, waarmee tevens bepaalde parameters in het model zijn gekalibreerd. Ondanks de goede voorspelling van de uitgescheiden hoeveelheden zit er behoorlijk veel variatie op de $Y=X$ lijn voor de concentraties van de verschillende componenten in de verse mest. Dit geldt vooral voor het ds-gehalte van de mest. Vooral een aantal berekende waarden in ronde 3 liggen beduidend boven de $Y=X$ lijn. Voor de andere componenten lijkt de spreiding meer willekeurig rond de $Y=X$ lijn te liggen, alleen lijken de hogere waarden iets vaker onder de $Y=X$ lijn te liggen dan de lagere waarden, waardoor de regressiecoëfficiënten allemaal een lagere waarde hebben dan 1. De oorzaak van de grote variatie in de verschillen tussen de berekende en de gemeten gehalten in de mest is moeilijk aan te geven. Het zou te maken kunnen hebben met de moeilijkheid om de waterbalans goed te voorspellen. Vooral de waterverdamping door het dier kan sterk variëren en dit heeft ook een sterk effect op de berekende wateruitscheiding. Het lijkt er op dat de vleeskuikens continu bezig zijn met het in balans houden van opgenomen en uitgescheiden hoeveelheden water. Op dit moment wordt de waterexcretie in het model bepaald door van de wateropname (+ metabolisch water) de waterverdamping en wateraanzet af te trekken. Deze benadering kan veel variatie in het watergehalte van de uitgescheiden mest veroorzaken. In de praktijk is deze variatie waarschijnlijk veel minder. Een andere benadering voor de waterexcretie zou kunnen zijn om de noodzakelijke wateruitscheiding te berekenen. 
Een vleeskuiken moet water uitscheiden voor afvoer van de fecescomponenten en voor afvoer van de urinecomponenten. In de literatuur is wel het één en ander bekend over de factoren die deze noodzakelijke uitscheidingen bepalen (o.a. effecten van verschillende mineralen op het watergehalte van de mest).

Het verloop van de concentraties van de verschillende componenten in de uitgescheiden feces over de groeiperiode wordt redelijk voorspeld. Voerovergangen zijn in de berekende waarden heel duidelijk terug te vinden, maar vrijwel niet in de gemeten waarden. Dit zou voor een deel verklaard kunnen worden door het feit dat de metingen slechts één maal per week zijn gedaan en de berekeningen voor alle dagen van de groeiperiode zijn gedaan. Het zou ook voor een deel verklaard kunnen worden door het feit dat de dieren vaak even moeten wennen aan het nieuwe voer en daardoor een paar dagen wat minder opnemen waardoor de concentraties in de mest anders reageren dan voorspeld zou worden zonder enige aanpassing door het dier.

Gezien de grote spreiding in de concentraties van de verschillende componenten in de uitgescheiden feces is het niet verwonderlijk dat er ook een behoorlijke spreiding zit op de concentraties in het strooisel. De spreiding lijkt echter niet groter te zijn dan die voor de feces. Wel lijkt er een duidelijk verschil te zijn tussen ronden voor met name Ntot en $\mathrm{K}$ gehalte van het strooisel, waarbij de waarden in ronde 3 allemaal onder de $Y=X$ lijn liggen. Het ammoniumgehalte van het strooisel wordt systematisch onderschat over de gehele range van alle groeiperioden. Hier zal nader naar moeten worden gekeken in het vervolgonderzoek. De ammoniakemissie lijkt een samenspel te zijn tussen de snelheid van omzetting van urinezuur naar ammonium en de vervluchtiging uit de mest als gevolg van de beïnvloedende factoren ammoniumgehalte en $\mathrm{pH}$ van het strooisel en van de luchtsnelheid (ventilatiedebiet in de meetbox) over het strooisel. De limiterende stap(pen) bepalen de concentraties urinezuur en ammonium en de emissiesnelheid van ammoniak.

De ammoniakemissie blijkt met het huidige model nog niet goed voorspeld te kunnen worden. Daarvoor hebben we beter inzicht nodig in het hiervoor genoemde samenspel tussen de snelheid van de urinezuuromzetting en de snelheid waarin de ammoniak vervluchtigt uit het strooisel. Uit de resultaten blijkt dat we de grote verschillen in ammoniakemissie die we hebben gemeten tussen de experimentele ronden beter kunnen verklaren wanneer we de snelheid van urinezuuromzetting variabel maken tussen ronden. Dan kunnen we de verschillen tussen ronden 1, 2 en 4 al een stuk beter verklaren. De hoge emissiewaarden van ronde 3 blijken dan nog steeds moeilijk te verklaren. Het lijkt er op dat in ronde 3 een acceleratie heeft plaatsgevonden waardoor de ammoniakemissie zeer hoog kon oplopen. Deze acceleratie kan veroorzaakt zijn door een relatief hoge urinezuuromzetting in ronde 3, waardoor het ammoniumgehalte stijgt. Met het ammoniumgehalte stijgt tevens de $\mathrm{pH}$. De $\mathrm{pH}$ is een zeer belangrijke drijvende factor voor de ammoniakemissie. De urinezuuromzetting is een bacterieel proces en dit proces is o.a. afhankelijk van de bacteriepopulaties die aanwezig zijn in de verse mest en van de omstandigheden in het strooisel. De eerste stap in de omzetting van urinezuur naar ammonium is een aeroob proces (Groot Koerkamp, 1994), dit betekent dat de bacteriën hiervoor zuurstof nodig hebben. In vochtig, dichtgeslagen strooisel, dus strooisel met een slechte rulheidsscore, treedt weinig zuurstof binnen. Dit zou de achtergrond kunnen zijn van het effect van rulheid op de ammoniakemissie. Het effect van rulheid wordt waarschijnlijk ook veroorzaakt door het feit dat ruller strooisel een groter emitterend oppervlak heeft. Met rulheid is echter maar een deel van de variatie binnen en tussen ronden te verklaren. Welke andere factor of factoren de omzetting van urinezuur bepalen is met de huidige stand van kennis moeilijk aan te geven. De hypothese is dat de bacteriepopulaties die aanwezig zijn in het darmkanaal van de vleeskuikens hierop weleens een belangrijke invloed zouden kunnen hebben. Door welke factoren deze darmpopulaties beïnvloed worden is op dit moment ook nog onduidelijk.

Dit onderzoek toont aan dat mogelijke effecten van een veranderende voersamenstelling volledig worden ondergesneeuwd door andere factoren die de ammoniakemissie veel meer lijken te beïnvloeden. Deze factoren zijn vooral de pH en de rulheid van het strooisel. De pH lijkt beïnvloed te worden door de omzettingssnelheid van urinezuur in het strooisel. Door welke factoren deze urinezuuromzetting wordt bepaald is op dit moment nog onduidelijk.

Ook is nog onduidelijk wat het precieze effect is van de rulheid van het strooisel. Deze rulheid wordt door de opbouw van het strooisel in het verleden bepaald (ontwikkeling ds-gehalte van strooisel) en 
door de actuele waterbalans van het strooisel (toevoeging water - verdamping water). De actuele waterbalans kan het strooisel in één keer dicht laten slaan en dit kan de ammoniakemissie sterk beïnvloeden. Kortom, er is op dit moment nog veel variatie in de ammoniakemissie uit strooiselhuisvesting voor vleeskuikens die we op dit moment nog niet goed begrijpen. Ook in praktijkstallen worden grote verschillen in ammoniakemissies tussen bedrijven en tussen ronden op hetzelfde bedrijf gevonden (Van Harn, persoonlijke mededeling). Als we een vinger achter de oorzaak van deze variaties kunnen krijgen dan biedt dit (nieuwe) mogelijkheden om de ammoniakemissie in vleeskuikenstallen te reduceren. Aangezien kalkoenen en leghennen in vergelijkbare omstandigheden worden gehouden (strooiselstallen), biedt dit misschien ook voor deze diercategorieën aanknopingspunten tot reductie van de ammoniakemissie. 


\section{Conclusies}

Uit de analyse van de resultaten en uit de modelberekeningen en - validatie kunnen we het volgende concluderen:

- Er is een grote variatie in de ammoniakemissie tussen de verschillende ronden. Het grootste verschil in ammoniakemissie was tussen ronden 3 en 4. De ammoniakemissie in ronde 3 was bijna een factor 10 hoger dan in ronde 4. Deze verschillen waren slechts voor een deel te verklaren met de huidige variabelen in het model (ammoniumgehalte, $\mathrm{pH}$, temperatuur, luchtsnelheid (ventilatiedebiet) en rulheid van het strooisel).

- Het eiwit- en het K-gehalte hadden geen significant (lineair) effect op de ammoniakemissie.

- Van de variabelen die, naar verwachting, de emissie vanuit de bron (het strooisel) beïnvloeden hebben de $\mathrm{pH}$ (regressiecoëfficiënt (r.c.) $=0.250$ (s.e. 0.072); $\mathrm{P}<0.001$ ), rulheid van het strooisel (r.c. $=0.112$ (s.e. 0.020); P<0.001) en het box-debiet (luchtsnelheid over het emitterend oppervlak; r.c. $=0.0223$ (s.e. 0.0039); $\mathrm{P}<0.001$ ) de sterkste invloed op de ammoniakemissie. De effecten van temperatuur (r.c. $=0.075$ (s.e. 0.035 ); $P=0.032$ ) en Ntot-gehalte (r.c. $=-0.030$ (s.e. 0.017); $\mathrm{P}=0.078$ ) van het strooisel zijn minder sterk. Het effect van $\mathrm{NH} 4-\mathrm{N}$-gehalte was niet significant ( r.c. $=0.052$ (s.e. 0.060); $\mathrm{P}=0.383$ ).

- Een hoger K-gehalte in het voer heeft een negatief effect op de productieresultaten, de strooiselkwaliteit en de voetzoollaesiescore.

- Het verstrekken van een voerprogramma met een verhoogd eiwitgehalte, maar met eenzelfde aminozurenpatroon, leidde niet tot een verhoogde wateropname of water/voer verhouding; ook de overige productieresultaten werden hierdoor niet beïnvloed. Het resulteerde wel in een toename van het aantal en ernst van hakdermatitis en voetzoollaesies.

- Het verstrekken van een voerprogramma met een verlaagd eiwitgehalte, maar met eenzelfde aminozurenpatroon, had geen aantoonbaar effect op de productieresultaten. Wel verslechterde de voerconversie enigszins. Het verstrekken van een laag eiwitvoer had geen effect op de ernst en voorkomen van voetzoollaesies en hakdermatitis.

- De ammoniakemissie blijkt met het huidige rekenmodel nog niet goed voorspeld te kunnen worden. Daarvoor is beter inzicht nodig in de snelheid van urinezuuromzetting en de snelheid waarin de ammoniak vervluchtigt uit het strooisel, mede in afhankelijkheid van de $\mathrm{pH}$ en de rulheid van het strooisel. 


\section{Aanbevelingen}

Aanbevolen wordt om extra onderzoek te doen naar de snelheid van de urinezuuromzetting in strooisel(mest). Deze lijkt sterk te kunnen verschillen tussen verschillende batches vleeskuikens. De oorzaak van deze verschillen moet achterhaald worden. Dit zou gedaan kunnen worden door verschillende strooiselmonsters te nemen uit verschillende praktijkstallen en van verschillende batches vleeskuikens. In een lab-opstelling kan de snelheid van urinezuuromzetting van deze verschillen in het strooisel worden bepaald en worden gerelateerd aan de karakteristieken van de stal en van de vleeskuikens (o.a. herkomst en broederijomstandigheden). 


\section{Literatuur}

Aarnink, A.J.A., Elzing, A. 1998. Dynamic model for ammonia volatilization in housing with partially slatted floors, for fattening pigs. Livest. Prod. Sci. 53: 153-169.

Aarnink, A.J.A., Van Ouwerkerk, E.N.J., Verstegen, M.W.A. 1992. A mathematical model for estimating the amount and composition of slurry from fattening pigs. Livest. Prod. Sci., 31, 133-147.

Anonymous. 2011. Handboek voor de Pluimveehouderij. Praktijkonderzoek Veehouderij, Animal Sciences Group, Lelystad.

Beeking, F.F.E., Ingelaat, F.B.J.M., van Beek, G. 1994. De specifieke vochtafgifte van leghennenmest. Report 607, COVP-DLO, Beekbergen.

CIGR. 2002. Heat and moisture production at animal and house levels. CIGR Working Group on Climatization of Animal Houses.

Dozier, W., Kidd, M., Corzo, A., Owens, P., Branton, S. 2008. Live performance and environmental impact of broiler chickens fed diets varying in amino acids and phytase. Animal feed science and technology, 141(1), 92-103.

Elwinger, K., Svensson, L. 1996. Effect of dietary protein content, litter and drinker type on ammonia emission from broiler houses. Journal of Agricultural Engineering Research, 64(3), 197-208.

Gates, R.S., Pescatore, A.J., Taraba, J., Cantor, A.H., Liberty, K., Ford, M.J., Burnham, D.J. 2000. Dietary manipulation of crude protein and amino acids for reduced ammonia emission from broiler litter. ASAE Annual International Meeting. 9-12 July 2000 Milwaukee, Wisconsin, USA. pp. 1-16.

Genstat Committee. 2014. GenStat Seventeenth Edition, Version-17.1.0.14713. VSN International Ltd, Hemel Hempstead, UK.

Gous, R., Moran, E., Stilborn, H., Bradford, G., Emmans, G. 1999. Evaluation of the parameters needed to describe the overall growth, the chemical growth, and the growth of feathers and breast muscles of broilers. Poultry Science, 78(6), 812-821.

Groot Koerkamp, P., Elzing, A. 1996. Degradation of nitrogenous components in and volatilization of ammonia from litter in aviary housing systems for laying hens. Transactions of the ASAE, 39(1), 211-218.

Groot Koerkamp, P.W.G. 1994. Review on emissions of ammonia from housing systems for laying hens in relation to sources, processes, building design and manure handling. J. Agric. Engng Res. 59, p. 7387.

Hancock, C., Bradford, G., Emmans, G., Gous, R. 1995. The evaluation of the growth parameters of six strains of commercial broiler chickens. British Poultry Science, 36(2), 247-264.

Harn, J.v., Ellen, H.H., Veldkamp, T., Aarnink, A.J.A. 2012. Effect van huisvestings- en managementmaatregelen op ammoniakemissie bij leghennen, vleeskuikers, kalkoenen en eenden. Wageningen UR Livestock Research. Rapport 560.

Holsheimer, J., Schutte, J., REUSINK, E., DE JONG, J. 1993. Eiwitverlaging van vleeskuikenvoeders in relatie tot de $\mathrm{N}$-excretie. Stikstof en fosfor in de voeding van eenmagige landbouwhuisdieren in relatie tot de milieuproblematiek. Produktschap voor veevoeding. Kwaliteitsreeks(25), 27-45.

Kielanowski, J. 1965. Estimates of the energy cost of protein deposition in growing animals. Proceedings of the 3rd Symposium on Energy Metabolism. EAAP Publ. no. 11. Academic Press, London, UK. pp. 1320.

Lopez, G., Leeson, S. 2008. Aspects of energy metabolism and energy partitioning in broiler chickens. CABI.

Morgan, N.K., Scholey, D.V., Burton, E.J. 2014. A comparison of two methods for determining titanium dioxide marker content in broiler digestibility studies. . Animal, 8, 529-533.

Mosquera, J., G.J. Kasper, K. Blanken, F. Dousma en A.J.A. Aarnink (2010). Ontwikkeling snelle meetmethode ter bepaling van ammoniakemissie reductie van vloergebonden maatregelen (=Development of a fast measurement method for the determination of ammonia emission reduction from floor related measures). Rapport 291

Nagaraj, M., Wilson, C., Hess, J., Bilgili, S. 2007. Effect of high-protein and all-vegetable diets on the incidence and severity of pododermatitis in broiler chickens. The Journal of Applied Poultry Research, 16(3), 304-312. 
Namroud, N., Shivazad, M., Zaghari, M. 2008. Effects of fortifying low crude protein diet with crystalline amino acids on performance, blood ammonia level, and excreta characteristics of broiler chicks. Poultry science, 87(11), 2250-2258.

Shepherd, E. M. en B. D. Fairchild (2010). Footpad dermatitis in poultry. Poult. Sci. 89:2043-2051.

Short, F.J., Gorton, P., Wiseman, J., Boorman, K.N. 1996. Determination of titanium dioxide added as an inert marker in chicken digestibility studies. Animal Feed Science \& Technology 59, 215-221.

Van Harn, J., de Jong, I. 2012. Minder eiwit, minder laesies. De Pluimveehouderij, 42(3), 22-23.

Van Harn, J., Van Middelkoop, J.H. 1996. Invloed van eiwitverlaging in voer op resultaten en stikstofuitscheiding bij vleeskuikens. Praktijkonderzoek 96/2.

Veldkamp, T., L. Star, J.D. van der Klis en J. van Harn, 2012. Reductie van ammoniakemissie op pluimveebedrijven via voeding. Rapport 490, Wageningen Livestock Research, Lelystad.

Welfare Quality ${ }^{\circledR}, 2009$. Welfare Quality ${ }^{\circledR}$ assessment protocol for poultry (broilers, laying hens). Welfare Quality ${ }^{\circledR}$ Consortium, Lelystad, The Netherlands. 


\section{Bijlage 1 Samenstelling basismelen start- en groei-/eindvoeders in ronde 1 en 2}

\begin{tabular}{|c|c|c|c|c|c|}
\hline \multicolumn{2}{|l|}{ Grondstof (g/ kg) } & \multicolumn{2}{|c|}{ Startvoer ( 0 - 10 dagen) } & \multicolumn{2}{|c|}{ Groei-/ eindvoer (11-35 dagen) } \\
\hline Mais & & 333,3 & 333,3 & 243,8 & 244,3 \\
\hline Tarwe + xylanase & & 250,0 & 250,0 & 350,0 & 350,0 \\
\hline Sojaschroot RC $<50$ & & 283,0 & 283,0 & 280,0 & 280,0 \\
\hline Maisglutenmeel & & 30,0 & 30,0 & -- & -- \\
\hline Raapschroot RE $<380$ & & 20,0 & 20,0 & 20,0 & 20,0 \\
\hline Plantaardige olie & & 37,5 & 37,5 & 66,5 & 66,5 \\
\hline Krijt (fijn gemalen) & & 14,0 & 19,0 & 11,5 & 15,5 \\
\hline Monocalciumfosfaat & & 13,0 & 2,5 & 8,5 & -- \\
\hline Zout & & 1,9 & 1,9 & 1,7 & 1,7 \\
\hline Natriumbicarbonaat & & 2,5 & 2,5 & 2,1 & 2,1 \\
\hline L-Lysine & & 2,4 & 2,4 & 2,0 & 2,0 \\
\hline DL-Methionine & & 1,9 & 1,9 & 2,2 & 2,2 \\
\hline L-Threonine & & 0,5 & 0,5 & 0,7 & 0,7 \\
\hline Vleeskuikenpremix $5 \mathrm{~g} / \mathrm{kg}$ & & 5,0 & 5,0 & 5,0 & 5,0 \\
\hline Bindmiddel & & 5,0 & -- & 6,0 & -- \\
\hline $\mathrm{KH}_{2} \mathrm{PO}_{4}$ & & -- & 10,5 & -- & 8,5 \\
\hline \multirow[t]{2}{*}{$\mathrm{KHCO}^{3}$} & & -- & -- & -- & 1,5 \\
\hline & & 1000,0 & 1000,0 & 1000,0 & 1000,0 \\
\hline \multicolumn{6}{|l|}{ Nutriëntengehalten } \\
\hline DS & $\mathrm{g} / \mathrm{kg}$ & 880 & 885 & 881 & 886 \\
\hline RAS & $\mathrm{g} / \mathrm{kg}$ & 59 & 59 & 51 & 52 \\
\hline RE & $\mathrm{g} / \mathrm{kg}$ & 220 & 220 & 204 & 204 \\
\hline RVET & $\mathrm{g} / \mathrm{kg}$ & 61 & 61 & 86 & 86 \\
\hline $\mathrm{RC}$ & $\mathrm{g} / \mathrm{kg}$ & 27 & 27 & 27 & 27 \\
\hline ZET (Ewers) & $\mathrm{g} / \mathrm{kg}$ & 379 & 379 & 377 & 378 \\
\hline $\mathrm{Ca}$ & $\mathrm{g} / \mathrm{kg}$ & 8,8 & 8,8 & 7,0 & 7,0 \\
\hline $\mathrm{P}$ & $\mathrm{g} / \mathrm{kg}$ & 6,5 & 6,5 & 5,5 & 5,5 \\
\hline OP & $\mathrm{g} / \mathrm{kg}$ & 4,0 & 4,0 & 3,1 & 3,1 \\
\hline $\mathrm{Ca} / \mathrm{oP}$ & & 2,2 & 2,2 & 2,3 & 2,3 \\
\hline $\mathrm{Mg}$ & $\mathrm{g} / \mathrm{kg}$ & 1,6 & 1,5 & 1,5 & 1,4 \\
\hline $\mathbf{K}$ & $\mathbf{g} / \mathbf{~ k g}$ & 8,0 & 11,0 & 8,0 & 11,0 \\
\hline $\mathrm{Na}$ & $\mathrm{g} / \mathrm{kg}$ & 1,5 & 1,5 & 1,3 & 1,3 \\
\hline $\mathrm{Cl}$ & $\mathrm{g} / \mathrm{kg}$ & 2,0 & 2,0 & 1,8 & 1,8 \\
\hline Base excess & $\mathrm{meq} / \mathrm{kg}$ & 213 & 290 & 211 & 287 \\
\hline OEslk & $\mathrm{MJ} / \mathrm{kg}$ & 11,9 & 11,9 & 12,6 & 12,6 \\
\hline vLYSp & $\mathrm{g} / \mathrm{kg}$ & 11,0 & 11,0 & 10,5 & 10,5 \\
\hline vMETp & $\mathrm{g} / \mathrm{kg}$ & 5,0 & 5,0 & 4,9 & 4,9 \\
\hline$v M+C p$ & $\mathrm{~g} / \mathrm{kg}$ & 8,0 & 8,0 & 7,7 & 7,7 \\
\hline vTHRp & $\mathrm{g} / \mathrm{kg}$ & 7,2 & 7,2 & 6,8 & 6,8 \\
\hline vTRPp & $\mathrm{g} / \mathrm{kg}$ & 2,2 & 2,2 & 2,1 & 2,1 \\
\hline vILEp & $\mathrm{g} / \mathrm{kg}$ & 8,0 & 8,0 & 7,4 & 7,4 \\
\hline VVALp & $\mathrm{g} / \mathrm{kg}$ & 8,7 & 8,7 & 8,1 & 8,1 \\
\hline vLEUp & $\mathrm{g} / \mathrm{kg}$ & 16,9 & 16,9 & 13,9 & 13,9 \\
\hline vARGp & $\mathrm{g} / \mathrm{kg}$ & 12,1 & 12,1 & 11,7 & 11,7 \\
\hline Linolzuur & $\mathrm{g} / \mathrm{kg}$ & 30,6 & 30,6 & 44,3 & 44,3 \\
\hline
\end{tabular}




\section{Bijlage 2 Samenstelling voeders ronde 3}

\begin{tabular}{|c|c|c|c|c|c|c|c|c|}
\hline & S1 & S2 & S3 & 54 & E1 & E2 & E3 & E4 \\
\hline Mais & 413.2 & 413.2 & 414.5 & 414.5 & 200.0 & 200.0 & 200.0 & 200.0 \\
\hline Tarwe & 194.8 & 194.8 & 229.3 & 229.3 & 460.7 & 460.7 & 488.6 & 488.6 \\
\hline Sojaschroot, $\mathrm{RC}<45 \mathrm{RE}<480$ & 166.5 & 166.5 & 162.7 & 162.7 & 203.2 & 203.2 & 194.3 & 194.3 \\
\hline Aardappeleiw. RAS $<10$ & 50.0 & 50.0 & 25.9 & 25.9 & 40.0 & 40.0 & 2.6 & 2.6 \\
\hline Maïsglutenmeel & 25.7 & 25.7 & 8.7 & 8.7 & 1.6 & 1.6 & 0.0 & 0.0 \\
\hline Zonblosr RC 160-200 & 70.0 & 70.0 & 70.0 & 70.0 & 3.3 & 3.3 & 12.1 & 12.1 \\
\hline Raapschroot RE $<380$ & 0.0 & 0.0 & 0.0 & 0.0 & 0.0 & 0.0 & 0.0 & 0.0 \\
\hline Sojaolie & 28.7 & 28.7 & 29.8 & 29.8 & 53.0 & 53.0 & 55.0 & 55.0 \\
\hline Krijt (fijn gemalen) & 15.3 & 15.3 & 15.4 & 15.4 & 11.4 & 11.4 & 11.4 & 11.4 \\
\hline Mono-Calcium fosfaat & 15.1 & 15.1 & 15.2 & 15.2 & 10.0 & 10.0 & 10.0 & 10.0 \\
\hline Landbouwzout & 1.0 & 1.0 & 0.4 & 0.4 & 1.8 & 1.8 & 1.0 & 1.0 \\
\hline Natriumbicarbonaat & 3.8 & 3.8 & 4.6 & 4.6 & 2.6 & 2.6 & 3.7 & 3.7 \\
\hline Kaliumcarbonaat & 0.0 & 2.7 & 0.0 & 2.7 & 0.0 & 2.7 & 0.0 & 2.7 \\
\hline Diamol & 3.0 & 0.3 & 3.0 & 0.3 & 3.0 & 0.3 & 3.0 & 0.3 \\
\hline Std vlkpremix $5 \mathrm{~g} / \mathrm{kg}$ & 5.0 & 5.0 & 5.0 & 5.0 & 5.0 & 5.0 & 5.0 & 5.0 \\
\hline Roxazyme G2; $0,1 \mathrm{~g} / \mathrm{kg}$ & 0.1 & 0.1 & 0.1 & 0.1 & 0.1 & 0.1 & 0.1 & 0.1 \\
\hline L-Lysine $\mathrm{HCl}$ & 3.8 & 3.8 & 5.6 & 5.6 & 1.7 & 1.7 & 4.4 & 4.4 \\
\hline DL-Methionine & 2.4 & 2.4 & 3.3 & 3.3 & 1.8 & 1.8 & 2.7 & 2.7 \\
\hline L-Threonine & 0.6 & 0.6 & 1.8 & 1.8 & 0.2 & 0.2 & 1.7 & 1.7 \\
\hline L-Tryptofaan & 0.2 & 0.2 & 0.5 & 0.5 & 0.0 & 0.0 & 0.3 & 0.3 \\
\hline L-Isoleucine & 0.0 & 0.0 & 1.0 & 1.0 & 0.0 & 0.0 & 0.8 & 0.8 \\
\hline L-Arginine & 0.9 & 0.9 & 2.1 & 2.1 & 0.6 & 0.6 & 2.0 & 2.0 \\
\hline L-Valine & 0.0 & 0.0 & 1.1 & 1.1 & 0.0 & 0.0 & 1.3 & 1.3 \\
\hline Totaal & 1000.0 & 1000.0 & 1000.0 & 1000.0 & 1000.0 & 1000.0 & 1000.0 & 1000.0 \\
\hline DS & 884 & 884 & 884 & 884 & 882 & 882 & 883 & 883 \\
\hline RAS & 64 & 64 & 65 & 65 & 53 & 53 & 54 & 54 \\
\hline RE & 220 & 220 & 200 & 200 & 200 & 200 & 180 & 180 \\
\hline RVETh & 60 & 60 & 60 & 60 & 78 & 78 & 79 & 79 \\
\hline $\mathrm{RC}$ & 33 & 33 & 34 & 34 & 24 & 24 & 26 & 26 \\
\hline ZETam & 368 & 368 & 384 & 384 & 382 & 382 & 397 & 397 \\
\hline $\mathrm{Ca}$ & 9.4 & 9.4 & 9.5 & 9.5 & 7.0 & 7.0 & 7.0 & 7.0 \\
\hline g & 7.0 & 7.0 & 7.0 & 7.0 & 5.6 & 5.6 & 5.6 & 5.6 \\
\hline $\mathrm{OP}$ & 4.0 & 4.0 & 4.0 & 4.0 & 3.1 & 3.1 & 3.1 & 3.1 \\
\hline $\mathrm{Ca}: \mathrm{oP}$ & 2.4 & 2.4 & 2.4 & 2.4 & 2.3 & 2.3 & 2.3 & 2.3 \\
\hline $\mathrm{Na}$ & 1.5 & 1.5 & 1.5 & 1.5 & 1.5 & 1.5 & 1.5 & 1.5 \\
\hline $\mathbf{K}$ & 7.0 & 8.5 & 7.0 & 8.5 & 7.0 & 8.5 & 7.0 & 8.5 \\
\hline $\mathrm{Cl}$ & 2.0 & 2.0 & 2.0 & 2.0 & 2.0 & 2.0 & 2.0 & 2.0 \\
\hline meq & 187 & 226 & 187 & 226 & 187 & 226 & 187 & 226 \\
\hline OEslk & 12.00 & 12.00 & 12.00 & 12.00 & 12.55 & 12.55 & 12.55 & 12.55 \\
\hline VLYSp & 11.9 & 11.9 & 11.9 & 11.9 & 10.2 & 10.2 & 10.2 & 10.2 \\
\hline VMETp & 5.9 & 5.9 & 6.2 & 6.2 & 4.7 & 4.7 & 5.0 & 5.0 \\
\hline $\mathrm{VM}+\mathrm{Cp}$ & 8.8 & 8.8 & 8.8 & 8.8 & 7.5 & 7.5 & 7.5 & 7.5 \\
\hline VTHRp & 7.7 & 7.7 & 7.7 & 7.7 & 6.6 & 6.6 & 6.6 & 6.6 \\
\hline VTRPp & 2.3 & 2.3 & 2.3 & 2.3 & 2.1 & 2.1 & 2.0 & 2.0 \\
\hline VARGp & 12.5 & 12.5 & 12.5 & 12.5 & 11.3 & 11.3 & 11.3 & 11.3 \\
\hline VVALp & 9.3 & 9.3 & 8.9 & 8.9 & 8.4 & 8.4 & 7.9 & 7.9 \\
\hline
\end{tabular}




\section{Bijlage 3 Voersamenstelling (ronde 4)}

\begin{tabular}{|c|c|c|c|c|c|c|c|c|c|c|c|c|}
\hline Voercode & $A E 2$ S1 & $A E 2 \_s 2$ & $A E 2 \_s 3$ & $A E 2 \_54$ & AE2_G1 & AE2_G2 & AE2_G3 & AE2_G4 & AE2_E1 & AE2_E2 & AE2_E3 & $A E 2 \_E 4$ \\
\hline \multicolumn{13}{|l|}{ Grondstof } \\
\hline Mais AE2 & 350.0 & 350.0 & 350.0 & 350.0 & 228.8 & 228.8 & 250.0 & 250.0 & 200.0 & 200.0 & 200.0 & 200.0 \\
\hline Tarwe AE2 & 258.4 & 258.4 & 288.7 & 288.7 & 401.1 & 401.1 & 407.9 & 407.9 & 464.8 & 464.8 & 497.2 & 497.2 \\
\hline Sojaschroot AE2 & 182.9 & 182.9 & 166.5 & 166.5 & 183.5 & 183.5 & 173.6 & 173.6 & 184.9 & 184.9 & 139.5 & 139.5 \\
\hline Aardappeleiwit AE1 & 70.7 & 70.7 & 36.2 & 36.2 & 53.0 & 53.0 & 16.5 & 16.5 & 27.5 & 27.5 & 5.0 & 5.0 \\
\hline Zonblosr RC 200-240 AE2 & 54.5 & 54.5 & 65.0 & 65.0 & 37.3 & 37.3 & 46.5 & 46.5 & 21.8 & 21.8 & 46.6 & 46.6 \\
\hline Sojaolie & 31.9 & 31.9 & 32.8 & 32.8 & 55.2 & 55.2 & 55.5 & 55.5 & 62.1 & 62.1 & 63.2 & 63.2 \\
\hline Krijt (fijn gemalen) & 14.2 & 14.2 & 14.1 & 14.1 & 10.3 & 10.3 & 10.3 & 10.3 & 9.3 & 9.3 & 9.2 & 9.2 \\
\hline $\begin{array}{l}\text { Mono-Calcium } \\
\text { fosfaat }\end{array}$ & 14.7 & 14.7 & 14.8 & 14.8 & 9.6 & 9.6 & 9.7 & 9.7 & 8.0 & 8.0 & 8.2 & 8.2 \\
\hline Landbouwzout & 1.5 & 1.5 & 0.7 & 0.7 & 1.8 & 1.8 & 1.0 & 1.0 & 1.9 & 1.9 & 1.0 & 1.0 \\
\hline Natriumbicarbonaat & 3.2 & 3.2 & 4.3 & 4.3 & 2.7 & 2.7 & 3.9 & 3.9 & 2.6 & 2.6 & 3.8 & 3.8 \\
\hline Kaliumcarbonaat & 0.0 & 3.6 & 0.2 & 3.8 & 0.0 & 3.6 & 0.0 & 3.6 & 0.0 & 3.6 & 0.9 & 4.5 \\
\hline Diamol & 4.0 & 0.4 & 4.0 & 0.4 & 4.0 & 0.4 & 4.0 & 0.4 & 4.0 & 0.4 & 4.0 & 0.4 \\
\hline $\begin{array}{l}\text { Std vlkpremix } 5 \\
\mathrm{~g} / \mathrm{kg}\end{array}$ & 5.0 & 5.0 & 5.0 & 5.0 & 5.0 & 5.0 & 5.0 & 5.0 & 5.0 & 5.0 & 5.0 & 5.0 \\
\hline Hostazym; $0,1 \mathrm{~g} / \mathrm{kg}$ & 0.1 & 0.1 & 0.1 & 0.1 & 0.1 & 0.1 & 0.1 & 0.1 & 0.1 & 0.1 & 0.1 & 0.1 \\
\hline Titaanoxide & 4.0 & 4.0 & 4.0 & 4.0 & 4.0 & 4.0 & 4.0 & 4.0 & 4.0 & 4.0 & 4.0 & 4.0 \\
\hline L-Lysine $\mathrm{HCl}$ & 2.1 & 2.1 & 4.8 & 4.8 & 1.5 & 1.5 & 4.2 & 4.2 & 1.6 & 1.6 & 4.3 & 4.3 \\
\hline DL-Methionine & 2.5 & 2.5 & 3.4 & 3.4 & 2.1 & 2.1 & 3.0 & 3.0 & 2.0 & 2.0 & 2.7 & 2.7 \\
\hline L-Threonine & 0.0 & 0.0 & 1.5 & 1.5 & 0.0 & 0.0 & 1.5 & 1.5 & 0.4 & 0.4 & 1.7 & 1.7 \\
\hline L-Tryptofaan & 0.0 & 0.0 & 0.4 & 0.4 & 0.0 & 0.0 & 0.3 & 0.3 & 0.0 & 0.0 & 0.3 & 0.3 \\
\hline L-I soleucine & 0.0 & 0.0 & 0.8 & 0.8 & 0.0 & 0.0 & 0.8 & 0.8 & 0.0 & 0.0 & 0.9 & 0.9 \\
\hline L-Arginine & 0.3 & 0.3 & 1.8 & 1.8 & 0.0 & 0.0 & 1.4 & 1.4 & 0.0 & 0.0 & 1.3 & 1.3 \\
\hline L-Valine & 0.0 & 0.0 & 0.9 & 0.9 & 0.0 & 0.0 & 0.8 & 0.8 & 0.0 & 0.0 & 1.1 & 1.1 \\
\hline Totaal & 1000.0 & 1000.0 & 1000.0 & 1000.0 & 1000.0 & 1000.0 & 1000.0 & 1000.0 & 1000.0 & 1000.0 & 1000.0 & 1000.0 \\
\hline
\end{tabular}




\section{Vervolg voersamenstelling ronde 4 (nutriëntengehalten)}

\begin{tabular}{|c|c|c|c|c|c|c|c|c|c|c|c|c|c|}
\hline \multicolumn{2}{|l|}{ Voercode } & $A E 2$ S1 & AE2_S2 & $A E 2$ S3 & AE2_S4 & AE2_G1 & AE2__G2 & AE2_G3 & $A E 2 \_G 4$ & AE2_E1 & AE2_E2 & AE2_E3 & AE2_E4 \\
\hline \multicolumn{2}{|c|}{ Verstrekkingsperiode } & \multicolumn{4}{|c|}{0 - 10 dagen } & \multicolumn{4}{|c|}{11 - 31 dagen } & \multicolumn{4}{|c|}{32 - 42 dagen } \\
\hline DS & $\mathrm{g}$ & 881 & 881 & 880 & 880 & 881 & 881 & 881 & 881 & 880 & 880 & 881 & 881 \\
\hline RAS & $\mathrm{g}$ & 67 & 67 & 68 & 68 & 57 & 57 & 58 & 58 & 54 & 54 & 55 & 55 \\
\hline RE & $\mathrm{g}$ & 220 & 220 & 200 & 200 & 205 & 205 & 185 & 185 & 185 & 185 & 165 & 165 \\
\hline RVETh & $\mathrm{g}$ & 60 & 60 & 60 & 60 & 80 & 80 & 80 & 80 & 86 & 86 & 86 & 86 \\
\hline RC & $\mathrm{g}$ & 32 & 32 & 34 & 34 & 29 & 29 & 31 & 31 & 27 & 27 & 31 & 31 \\
\hline ZETam & $\mathrm{g}$ & 357 & 357 & 373 & 373 & 363 & 363 & 379 & 379 & 381 & 381 & 398 & 398 \\
\hline SUI & $\mathrm{g}$ & 35 & 35 & 34 & 34 & 36 & 36 & 36 & 36 & 36 & 36 & 34 & 34 \\
\hline NSP & $g$ & 144 & 144 & 147 & 147 & 141 & 141 & 144 & 144 & 139 & 139 & 144 & 144 \\
\hline $\mathrm{Ca}$ & $\mathrm{g}$ & 9.00 & 9.00 & 9.00 & 9.00 & 6.90 & 6.90 & 6.90 & 6.90 & 6.30 & 6.30 & 6.30 & 6.30 \\
\hline $\mathrm{P}$ & $\mathrm{g}$ & 6.99 & 6.99 & 7.06 & 7.06 & 5.80 & 5.80 & 5.86 & 5.86 & 5.37 & 5.37 & 5.45 & 5.45 \\
\hline $\mathrm{Ca} / \mathrm{P}$ & $\mathrm{g}$ & 1.29 & 1.29 & 1.28 & 1.28 & 1.19 & 1.19 & 1.18 & 1.18 & 1.17 & 1.17 & 1.16 & 1.16 \\
\hline OP & $\mathrm{g}$ & 4.00 & 4.00 & 4.00 & 4.00 & 3.10 & 3.10 & 3.10 & 3.10 & 2.80 & 2.80 & 2.80 & 2.80 \\
\hline Ca: oP & & 2.25 & 2.25 & 2.25 & 2.25 & 2.23 & 2.23 & 2.23 & 2.23 & 2.25 & 2.25 & 2.25 & 2.25 \\
\hline $\mathrm{Na}$ & $\mathrm{g}$ & 1.50 & 1.50 & 1.50 & 1.50 & 1.50 & 1.50 & 1.50 & 1.50 & 1.50 & 1.50 & 1.50 & 1.50 \\
\hline K & $\mathrm{g}$ & 7.00 & 9.00 & 7.00 & 9.00 & 7.00 & 9.00 & 7.00 & 9.00 & 7.00 & 9.00 & 7.00 & 9.00 \\
\hline $\mathrm{Cl}$ & g & 2.00 & 2.00 & 2.00 & 2.00 & 2.00 & 2.00 & 2.00 & 2.00 & 2.00 & 2.00 & 2.00 & 2.00 \\
\hline EB & $\mathrm{kg}$ & 188 & 239 & 188 & 239 & 188 & 239 & 188 & 239 & 188 & 239 & 188 & 239 \\
\hline OEslk & MJ & 12.00 & 12.00 & 12.00 & 12.00 & 12.55 & 12.55 & 12.55 & 12.55 & 12.76 & 12.76 & 12.76 & 12.76 \\
\hline VLYSp & $\mathrm{g}$ & 11.9 & 11.9 & 11.9 & 11.9 & 10.5 & 10.5 & 10.5 & 10.5 & 9.2 & 9.2 & 9.2 & 9.2 \\
\hline VMETp & $g$ & 6.0 & 6.0 & 6.2 & 6.2 & 5.3 & 5.3 & 5.6 & 5.6 & 4.7 & 4.7 & 4.9 & 4.9 \\
\hline VCYSp & $\mathrm{g}$ & 2.9 & 2.9 & 2.6 & 2.6 & 2.8 & 2.8 & 2.5 & 2.5 & 2.6 & 2.6 & 2.3 & 2.3 \\
\hline $\mathrm{VM}+\mathrm{Cp}$ & $\mathrm{g}$ & 8.8 & 8.8 & 8.8 & 8.8 & 8.0 & 8.0 & 8.0 & 8.0 & 7.2 & 7.2 & 7.2 & 7.2 \\
\hline VTHRp & $\mathrm{g}$ & 7.7 & 7.7 & 7.7 & 7.7 & 6.9 & 6.9 & 6.9 & 6.9 & 6.2 & 6.2 & 6.2 & 6.2 \\
\hline VTRPp & $\mathrm{g}$ & 2.3 & 2.3 & 2.3 & 2.3 & 2.2 & 2.2 & 2.1 & 2.1 & 1.9 & 1.9 & 1.9 & 1.9 \\
\hline VILEp & $\mathrm{g}$ & 8.6 & 8.6 & 7.9 & 7.9 & 7.9 & 7.9 & 7.2 & 7.2 & 6.8 & 6.8 & 6.3 & 6.3 \\
\hline VARGp & $\mathrm{g}$ & 12.5 & 12.5 & 12.5 & 12.5 & 11.3 & 11.3 & 11.3 & 11.3 & 10.2 & 10.2 & 9.8 & 9.8 \\
\hline
\end{tabular}




\section{Bijlage $4 \quad$ Klimaatinstellingen}

\section{Eerste en tweede ronde}

\begin{tabular}{|c|c|c|c|c|c|c|c|c|c|}
\hline \multirow[t]{2}{*}{ Dagnummer } & \multicolumn{4}{|c|}{ Eerste ronde } & \multicolumn{5}{|c|}{ Tweede ronde } \\
\hline & $\begin{array}{l}\text { Stal T } \\
\left({ }^{\circ} \mathrm{C}\right)\end{array}$ & $\begin{array}{l}\text { Debiet } \\
\text { ( } m^{3} / \text { uur) }\end{array}$ & $\begin{array}{l}\text { CEL } 30 \\
\text { RV }(\%)\end{array}$ & $\begin{array}{l}\text { CEL } 32 \\
\text { RV (\%) }\end{array}$ & $\begin{array}{l}\text { Stal } \\
\mathrm{T} \\
\left({ }^{\circ} \mathrm{C}\right)\end{array}$ & $\begin{array}{l}\text { RV } \\
(\%)\end{array}$ & $\begin{array}{l}\text { CEL } 32 \\
\text { Debiet } \\
\text { ( } \mathrm{m}^{3} / \text { uur) }\end{array}$ & $\begin{array}{l}\text { CEL } 30 \\
\text { Debiet } \\
\text { ( } \mathrm{m}^{3} / \text { uur) }\end{array}$ & $\begin{array}{l}\text { Stal } \\
\mathrm{T} \\
\left({ }^{\circ} \mathrm{C}\right)\end{array}$ \\
\hline 1 & 34.0 & 300 & 40,0 & 40,0 & 34,0 & 40,0 & 300 & 600 & 34,0 \\
\hline 2 & 33.3 & 300 & 40,7 & 42,5 & 33,3 & 40,7 & 300 & 600 & 33,3 \\
\hline 3 & 32.7 & 300 & 41,4 & 45,0 & 32,7 & 41,4 & 300 & 600 & 32,7 \\
\hline 4 & 32.0 & 300 & 42,1 & 47,5 & 32,0 & 42,1 & 300 & 600 & 32,0 \\
\hline 5 & 31.3 & 300 & 42,9 & 50,0 & 31,3 & 42,9 & 300 & 600 & 31,3 \\
\hline 6 & 30.7 & 300 & 43,6 & 52,5 & 30,7 & 43,6 & 300 & 600 & 30,7 \\
\hline 7 & 30.0 & 300 & 44,3 & 55,0 & 30,0 & 44,3 & 300 & 600 & 30,0 \\
\hline 8 & 29.8 & 300 & 45,0 & 57,5 & 29,8 & 45,0 & 300 & 600 & 29,8 \\
\hline 9 & 29.6 & 300 & 45,7 & 60,0 & 29,6 & 45,7 & 300 & 600 & 29,6 \\
\hline 10 & 29.4 & 300 & 46,4 & 62,5 & 29,4 & 46,4 & 300 & 600 & 29,4 \\
\hline 11 & 29.2 & 300 & 47,1 & 65,0 & 29,2 & 47,1 & 300 & 600 & 29,2 \\
\hline 12 & 29.0 & 300 & 47,9 & 67,5 & 29,0 & 47,9 & 300 & 600 & 29,0 \\
\hline 13 & 28.8 & 300 & 48,6 & 70,0 & 28,8 & 48,6 & 300 & 600 & 28,8 \\
\hline 14 & 28.6 & 300 & 49,3 & 72,5 & 28,6 & 49,3 & 300 & 600 & 28,6 \\
\hline 15 & 28.4 & 300 & 50,0 & 75,0 & 28,4 & 50,0 & 300 & 600 & 28,4 \\
\hline 16 & 28.2 & 300 & 50,0 & 75,0 & 28,2 & 50,0 & 300 & 600 & 28,2 \\
\hline 17 & 28.0 & 300 & 50,0 & 75,0 & 28,0 & 50,0 & 300 & 600 & 28,0 \\
\hline 18 & 27.3 & 300 & 50,0 & 75,0 & 27,3 & 50,0 & 300 & 600 & 27,3 \\
\hline 19 & 26.5 & 300 & 50,0 & 75,0 & 26,5 & 50,0 & 300 & 600 & 26,5 \\
\hline 20 & 25.8 & 300 & 50,0 & 75,0 & 25,8 & 50,0 & 300 & 600 & 25,8 \\
\hline 21 & 25.0 & 300 & 50,0 & 75,0 & 25,0 & 50,0 & 300 & 600 & 25,0 \\
\hline 22 & 24.6 & 314 & 50,0 & 75,0 & 24,6 & 50,0 & 314 & 628 & 24,6 \\
\hline 23 & 24.1 & 329 & 50,0 & 75,0 & 24,1 & 50,0 & 329 & 658 & 24,1 \\
\hline 24 & 23.7 & 343 & 50,0 & 75,0 & 23,7 & 50,0 & 343 & 686 & 23,7 \\
\hline 25 & 23.3 & 357 & 50,0 & 75,0 & 23,3 & 50,0 & 357 & 714 & 23,3 \\
\hline 26 & 22.9 & 371 & 50,0 & 75,0 & 22,9 & 50,0 & 371 & 742 & 22,9 \\
\hline 27 & 22.4 & 386 & 50,0 & 75,0 & 22,4 & 50,0 & 386 & 772 & 22,4 \\
\hline 28 & 22.0 & 400 & 50,0 & 75,0 & 22,0 & 50,0 & 400 & 800 & 22,0 \\
\hline 29 & 21.7 & 414 & 50,0 & 75,0 & 21,7 & 50,0 & 414 & 828 & 21,7 \\
\hline 30 & 21.4 & 429 & 50,0 & 75,0 & 21,4 & 50,0 & 429 & 858 & 21,4 \\
\hline 31 & 21.1 & 443 & 50,0 & 75,0 & 21,1 & 50,0 & 443 & 886 & 21,1 \\
\hline 32 & 20.9 & 457 & 50,0 & 75,0 & 20,9 & 50,0 & 457 & 914 & 20,9 \\
\hline 33 & 20.6 & 471 & 50,0 & 75,0 & 20,6 & 50,0 & 471 & 942 & 20,6 \\
\hline 34 & 20.3 & 486 & 50,0 & 75,0 & 20,3 & 50,0 & 486 & 972 & 20,3 \\
\hline 35 & 20.0 & 500 & 50,0 & 75,0 & 20,0 & 50,0 & 500 & 1000 & 20,0 \\
\hline
\end{tabular}




\section{Vervolg Bijlage 4 Klimaatinstellingen}

\section{Derde ronde}

\begin{tabular}{|c|c|c|c|c|}
\hline Dagnummer & Stal T $\left({ }^{\circ} \mathrm{C}\right)$ & Debiet ( $\mathrm{m}^{3} / \mathrm{uur}$ ) & CEL 32 RV (\% ) & CEL 34 RV (\%) \\
\hline 1 & 34,0 & 300 & 40,0 & 40,0 \\
\hline 2 & 33,3 & 300 & 40,8 & 41,7 \\
\hline 3 & 32,7 & 300 & 41,5 & 43,3 \\
\hline 4 & 32,0 & 300 & 42,3 & 45,0 \\
\hline 5 & 31,3 & 300 & 43,1 & 46,7 \\
\hline 6 & 30,7 & 300 & 43,8 & 48,3 \\
\hline 7 & 30,0 & 300 & 44,6 & 50,0 \\
\hline 8 & 29,8 & 300 & 45,4 & 51,4 \\
\hline 9 & 29,6 & 300 & 46,2 & 52,9 \\
\hline 10 & 29,4 & 300 & 46,9 & 54,3 \\
\hline 11 & 29,2 & 300 & 47,7 & 55,7 \\
\hline 12 & 29,0 & 300 & 48,5 & 57,1 \\
\hline 13 & 28,8 & 300 & 49,2 & 58,6 \\
\hline 14 & 28,6 & 300 & 50,0 & 60,0 \\
\hline 15 & 28,4 & 300 & 50,0 & 60,0 \\
\hline 16 & 28,2 & 300 & 50,0 & 60,0 \\
\hline 17 & 28,0 & 300 & 50,0 & 60,0 \\
\hline 18 & 27,3 & 300 & 50,0 & 60,0 \\
\hline 19 & 26,5 & 300 & 50,0 & 60,0 \\
\hline 20 & 25,8 & 300 & 50,0 & 60,0 \\
\hline 21 & 25,0 & 300 & 50,0 & 60,0 \\
\hline 22 & 24,6 & 314 & 50,0 & 60,0 \\
\hline 23 & 24,1 & 329 & 50,0 & 60,0 \\
\hline 24 & 23,7 & 343 & 50,0 & 60,0 \\
\hline 25 & 23,3 & 357 & 50,0 & 60,0 \\
\hline 26 & 22,9 & 371 & 50,0 & 60,0 \\
\hline 27 & 22,4 & 386 & 50,0 & 60,0 \\
\hline 28 & 22,0 & 400 & 50,0 & 60,0 \\
\hline 29 & 21,7 & 414 & 50,0 & 65,0 \\
\hline 30 & 21,4 & 429 & 50,0 & 65,0 \\
\hline 31 & 21,1 & 443 & 50,0 & 65,0 \\
\hline 32 & 20,9 & 457 & 50,0 & 65,0 \\
\hline 33 & 20,6 & 471 & 50,0 & 65,0 \\
\hline 34 & 20,3 & 486 & 50,0 & 65,0 \\
\hline 35 & 20,0 & 500 & 50,0 & 65,0 \\
\hline
\end{tabular}




\section{Vervolg Bijlage $4 \quad$ Klimaatinstellingen}

\section{Vierde ronde}

\begin{tabular}{|c|c|c|c|}
\hline Dagnummer & Stal T $\left({ }^{\circ} \mathrm{C}\right)$ & RV (\%) & $\begin{array}{l}\text { Debiet }\left(\mathrm{m}^{3} / \text { uur) }\right. \\
\left(1,2 \mathrm{~m}^{3} / \mathrm{kg} \text { per uur) }\right.\end{array}$ \\
\hline 1 & 34,0 & 40,0 & 300 \\
\hline 2 & 33,3 & 41,7 & 300 \\
\hline 3 & 32,7 & 43,3 & 300 \\
\hline 4 & 32,0 & 45,0 & 300 \\
\hline 5 & 31,3 & 46,7 & 300 \\
\hline 6 & 30,7 & 48,3 & 300 \\
\hline 7 & 30,0 & 50,0 & 300 \\
\hline 8 & 29,8 & 51,4 & 300 \\
\hline 9 & 29,6 & 52,9 & 300 \\
\hline 10 & 29,4 & 54,3 & 300 \\
\hline 11 & 29,2 & 55,7 & 300 \\
\hline 12 & 29,0 & 57,1 & 300 \\
\hline 13 & 28,8 & 58,6 & 300 \\
\hline 14 & 28,6 & 60,0 & 300 \\
\hline 15 & 28,4 & 60,0 & 300 \\
\hline 16 & 28,2 & 60,0 & 300 \\
\hline 17 & 28,0 & 60,0 & 300 \\
\hline 18 & 27,3 & 60,0 & 300 \\
\hline 19 & 26,5 & 60,0 & 300 \\
\hline 20 & 25,8 & 60,0 & 300 \\
\hline 21 & 25,0 & 60,0 & 300 \\
\hline 22 & 24,6 & 60,0 & 300 \\
\hline 23 & 24,1 & 60,0 & 300 \\
\hline 24 & 23,7 & 60,0 & 300 \\
\hline 25 & 23,3 & 60,0 & 322 \\
\hline 26 & 22,9 & 60,0 & 345 \\
\hline 27 & 22,4 & 60,0 & 368 \\
\hline 28 & 22,0 & 60,0 & 391 \\
\hline 29 & 21,7 & 65,0 & 416 \\
\hline 30 & 21,4 & 65,0 & 440 \\
\hline 31 & 21,1 & 65,0 & 465 \\
\hline 32 & 20,9 & 65,0 & 490 \\
\hline 33 & 20,6 & 65,0 & 515 \\
\hline 34 & 20,3 & 65,0 & 541 \\
\hline 35 & 20,0 & 65,0 & 567 \\
\hline 36 & 19,8 & 70,0 & 593 \\
\hline 37 & 19,6 & 70,0 & 619 \\
\hline 38 & 19,5 & 70,0 & 646 \\
\hline 39 & 19,3 & 70,0 & 672 \\
\hline 40 & 19,2 & 70,0 & 698 \\
\hline 41 & 19,1 & 70,0 & 725 \\
\hline 42 & 19,0 & 70,0 & 751 \\
\hline
\end{tabular}




\section{Bijlage 5 Gerealiseerde temperaturen, relatieve luchtvochtigheden en ventilatiedebieten per klimaatcel}

\section{Eerste ronde}

\begin{tabular}{|c|c|c|c|c|c|c|c|}
\hline & & & CEL 30 & & & CEL 32 & \\
\hline Datum & Dagno. & RV (\%) & $\mathrm{T}\left({ }^{\circ} \mathrm{C}\right)$ & $\begin{array}{l}\text { Debiet } \\
\text { ( } \mathrm{m}^{3} / \text { uur) }\end{array}$ & RV (\%) & $\mathrm{T}\left({ }^{\circ} \mathrm{C}\right)$ & $\begin{array}{l}\text { Debiet } \\
\text { (m³/uur) }\end{array}$ \\
\hline 23-11-2012 & 0 & 38,4 & 34,2 & 360 & 40,8 & 34,4 & 410 \\
\hline 24-11-2012 & 1 & 39,7 & 33,4 & 379 & 42,2 & 33,4 & 330 \\
\hline $25-11-2012$ & 2 & 40,2 & 32,8 & 401 & 44,3 & 32,8 & 337 \\
\hline 26-11-2012 & 3 & 40,4 & 32,0 & 397 & 47,3 & 32,0 & 339 \\
\hline 27-11-2012 & 4 & 41,2 & 31,3 & 414 & 49,5 & 31,3 & 332 \\
\hline 28-11-2012 & 5 & 42,4 & 30,7 & 418 & 52,2 & 30,8 & 334 \\
\hline 29-11-2012 & 6 & 42,2 & 30,0 & 398 & 54,4 & 30,0 & 337 \\
\hline 30-11-2012 & 7 & 43,0 & 29,8 & 383 & 57,3 & 29,8 & 295 \\
\hline $1-12-2012$ & 8 & 44,3 & 29,6 & 383 & 60,0 & 29,6 & 302 \\
\hline $2-12-2012$ & 9 & 44,7 & 29,4 & 372 & 62,3 & 29,4 & 297 \\
\hline 3-12-2012 & 10 & 45,1 & 29,2 & 372 & 64,4 & 29,2 & 301 \\
\hline 4-12-2012 & 11 & 46,5 & 29,0 & 351 & 67,0 & 28,8 & 302 \\
\hline 5-12-2012 & 12 & 47,0 & 28,8 & 321 & 69,4 & 28,8 & 300 \\
\hline $6-12-2012$ & 13 & 47,4 & 28,6 & 340 & 72,4 & 28,6 & 299 \\
\hline 7-12-2012 & 14 & 48,7 & 28,4 & 319 & 75,4 & 28,1 & 746 \\
\hline 8-12-2012 & 15 & 48,4 & 28,2 & 369 & 75,0 & 28,2 & 305 \\
\hline $9-12-2012$ & 16 & 49,1 & 28,0 & 370 & 74,9 & 27,9 & 331 \\
\hline $10-12-2012$ & 17 & 48,5 & 27,3 & 373 & 75,0 & 27,3 & 338 \\
\hline $11-12-2012$ & 18 & 48,6 & 26,6 & 422 & 75,1 & 26,4 & 335 \\
\hline $12-12-2012$ & 19 & 49,0 & 25,9 & 406 & 75,1 & 25,8 & 341 \\
\hline $13-12-2012$ & 20 & 49,0 & 25,1 & 404 & 75,0 & 25,1 & 329 \\
\hline $14-12-2012$ & 21 & 48,8 & 24,6 & 367 & 75,2 & 24,6 & 314 \\
\hline $15-12-2012$ & 22 & 49,8 & 24,1 & 389 & 75,2 & 24,1 & 361 \\
\hline $16-12-2012$ & 23 & 49,7 & 23,7 & 412 & 75,2 & 23,7 & 374 \\
\hline $17-12-2012$ & 24 & 50,0 & 23,3 & 386 & 75,0 & 23,3 & 383 \\
\hline $18-12-2012$ & 25 & 50,0 & 22,9 & 406 & 74,9 & 22,8 & 406 \\
\hline $19-12-2012$ & 26 & 51,1 & 22,4 & 379 & 74,9 & 22,3 & 409 \\
\hline $20-12-2012$ & 27 & 49,5 & 22,0 & 428 & 75,0 & 22,0 & 426 \\
\hline $21-12-2012$ & 28 & 49,8 & 21,6 & 419 & 75,2 & 21,7 & 443 \\
\hline $22-12-2012$ & 29 & 53,1 & 21,4 & 456 & 75,0 & 21,3 & 428 \\
\hline $23-12-2012$ & 30 & 55,4 & 21,0 & 447 & 74,9 & 21,1 & 443 \\
\hline $24-12-2012$ & 31 & 55,6 & 20,8 & 461 & 74,8 & 20,9 & 452 \\
\hline $25-12-2012$ & 32 & 55,0 & 20,5 & 496 & 74,8 & 20,5 & 471 \\
\hline $26-12-2012$ & 33 & 54,8 & 20,2 & 486 & 74,9 & 20,2 & 480 \\
\hline $27-12-2012$ & 34 & 54,4 & 19,8 & 531 & 75,0 & 19,9 & 503 \\
\hline
\end{tabular}




\section{Tweede ronde}

\begin{tabular}{|c|c|c|c|c|c|c|c|}
\hline \multirow[t]{2}{*}{ Datum } & \multirow[t]{2}{*}{ Dagno. } & \multicolumn{3}{|c|}{ CEL 32} & \multicolumn{3}{|c|}{ CEL 30} \\
\hline & & RV (\%) & $\mathrm{T}\left({ }^{\circ} \mathrm{C}\right)$ & $\begin{array}{l}\text { Debiet } \\
\text { (m³/uur) }\end{array}$ & RV (\%) & $\mathrm{T}\left({ }^{\circ} \mathrm{C}\right)$ & $\begin{array}{l}\text { Debiet } \\
\text { ( } \mathrm{m}^{3} / \mathrm{ur} \text { ) }\end{array}$ \\
\hline $15-1-2013$ & 0 & 40,1 & 34,4 & 360 & 36,4 & 34,5 & 884 \\
\hline $16-1-2013$ & 1 & 39,7 & 33,4 & 408 & 35,6 & 33,3 & 617 \\
\hline $17-1-2013$ & 2 & 38,4 & 32,8 & 408 & 38,0 & 32,8 & 622 \\
\hline $18-1-2013$ & 3 & 38,5 & 32,1 & 386 & 38,7 & 32,0 & 617 \\
\hline 19-1-2013 & 4 & 41,2 & 31,3 & 365 & 40,3 & 31,3 & 621 \\
\hline 20-1-2013 & 5 & 42,5 & 30,7 & 340 & 39,9 & 30,7 & 601 \\
\hline 21-1-2013 & 6 & 42,6 & 30,1 & 322 & 42,2 & 30,0 & 620 \\
\hline $22-1-2013$ & 7 & 43,7 & 29,8 & 338 & 42,5 & 29,9 & 621 \\
\hline 23-1-2013 & 8 & 44,7 & 29,6 & 334 & 44,3 & 29,6 & 617 \\
\hline 24-1-2013 & 9 & 45,5 & 29,4 & 347 & 46,2 & 29,5 & 601 \\
\hline 25-1-2013 & 10 & 46,3 & 29,2 & 348 & 45,1 & 29,1 & 599 \\
\hline 26-1-2013 & 11 & 47,2 & 29,0 & 352 & 47,9 & 29,0 & 619 \\
\hline 27-1-2013 & 12 & 47,7 & 28,8 & 352 & 48,6 & 28,8 & 599 \\
\hline 28-1-2013 & 13 & 48,7 & 28,6 & 358 & 49,3 & 28,6 & 597 \\
\hline 29-1-2013 & 14 & 48,9 & 28,4 & 360 & 49,3 & 28,5 & 602 \\
\hline 30-1-2013 & 15 & 49,1 & 28,2 & 355 & 47,3 & 28,2 & 601 \\
\hline $31-1-2013$ & 16 & 49,4 & 28,0 & 364 & 50,0 & 28,0 & 601 \\
\hline $1-2-2013$ & 17 & 49,3 & 27,3 & 389 & 50,0 & 27,3 & 616 \\
\hline $2-2-2013$ & 18 & 49,3 & 26,6 & 381 & 50,0 & 26,6 & 617 \\
\hline $3-2-2013$ & 19 & 49,1 & 25,8 & 409 & 50,1 & 25,9 & 622 \\
\hline $4-2-2013$ & 20 & 48,9 & 24,9 & 396 & 50,1 & 25,1 & 622 \\
\hline $5-2-2013$ & 21 & 48,8 & 24,6 & 382 & 49,1 & 24,6 & 636 \\
\hline $6-2-2013$ & 22 & 49,0 & 24,2 & 385 & 50,0 & 24,1 & 667 \\
\hline $7-2-2013$ & 23 & 49,3 & 23,7 & 379 & 50,0 & 23,7 & 701 \\
\hline 8-2-2013 & 24 & 49,0 & 23,3 & 365 & 50,1 & 23,3 & 725 \\
\hline $9-2-2013$ & 25 & 49,5 & 23,0 & 421 & 50,2 & 22,9 & 756 \\
\hline $10-2-2013$ & 26 & 49,4 & 22,5 & 416 & 50,1 & 22,4 & 787 \\
\hline $11-2-2013$ & 27 & 49,3 & 22,0 & 397 & 50,1 & 22,1 & 798 \\
\hline $12-2-2013$ & 28 & 48,8 & 21,7 & 441 & 50,1 & 21,7 & 823 \\
\hline $13-2-2013$ & 29 & 48,8 & 21,2 & 429 & 49,9 & 21,4 & 868 \\
\hline $14-2-2013$ & 30 & 48,7 & 21,3 & 470 & 50,1 & 21,1 & 885 \\
\hline $15-2-2013$ & 31 & 49,5 & 20,8 & 462 & 49,9 & 20,9 & 917 \\
\hline $16-2-2013$ & 32 & 50,5 & 20,3 & 496 & 50,1 & 20,6 & 949 \\
\hline $17-2-2013$ & 33 & 49,8 & 20,2 & 487 & 49,8 & 20,3 & 970 \\
\hline $18-2-2013$ & 34 & 49,9 & 19,9 & 500 & 50,1 & 20,0 & 995 \\
\hline $19-2-2013$ & 35 & 49,9 & 19,8 & 500 & 49,6 & 20,0 & 1004 \\
\hline
\end{tabular}




\section{Derde ronde}

\begin{tabular}{|c|c|c|c|c|c|c|c|}
\hline \multirow[t]{2}{*}{ Datum } & \multirow[t]{2}{*}{ Dagno. } & \multicolumn{3}{|c|}{ Cel 32} & \multicolumn{3}{|c|}{ Cel 34} \\
\hline & & $\begin{array}{l}\text { RV } \\
(\%)\end{array}$ & $\mathrm{T}\left({ }^{\circ} \mathrm{C}\right)$ & $\begin{array}{l}\text { Debiet } \\
\text { ( } \mathrm{m}^{3} / \text { uur) }\end{array}$ & $\mathrm{RV}(\%)$ & $\mathrm{T}\left({ }^{\circ} \mathrm{C}\right)$ & $\begin{array}{l}\text { Debiet } \\
\text { ( } m^{3} / \text { uur) }\end{array}$ \\
\hline 4-7-2014 & 0 & 39,2 & 33,6 & 388,7 & 40,0 & 34,0 & 434,0 \\
\hline 5-7-2014 & 1 & 40,1 & 33,6 & 359,4 & 40,1 & 33,5 & 423,9 \\
\hline 6-7-2014 & 2 & 41,0 & 32,9 & 384,0 & 41,5 & 32,9 & 421,7 \\
\hline 7-7-2014 & 3 & 41,2 & 32,2 & 383,3 & 42,9 & 32,2 & 424,6 \\
\hline 8-7-2014 & 4 & 41,9 & 31,5 & 380,1 & 44,3 & 31,5 & 423,3 \\
\hline 9-7-2014 & 5 & 43,5 & 30,9 & 393,0 & 46,5 & 30,9 & 431,0 \\
\hline $10-7-2014$ & 6 & 45,8 & 30,2 & 372,1 & 49,0 & 30,1 & 425,3 \\
\hline $11-7-2014$ & 7 & 45,7 & 29,8 & 376,2 & 49,8 & 29,8 & 427,6 \\
\hline $12-7-2014$ & 8 & 42,3 & 29,6 & 341,2 & 47,3 & 29,7 & 423,2 \\
\hline $13-7-2014$ & 9 & 46,1 & 29,5 & 330,7 & 52,1 & 29,5 & 434,1 \\
\hline $14-7-2014$ & 10 & 47,5 & 29,3 & 392,2 & 53,3 & 29,3 & 430,4 \\
\hline $15-7-2014$ & 11 & 47,6 & 29,1 & 387,7 & 55,4 & 29,1 & 425,9 \\
\hline $16-7-2014$ & 12 & 45,7 & 28,9 & 344,3 & 52,2 & 28,9 & 428,2 \\
\hline $17-7-2014$ & 13 & 46,3 & 28,7 & 337,2 & 53,6 & 28,6 & 428,0 \\
\hline $18-7-2014$ & 14 & 50,2 & 28,4 & 326,7 & 55,2 & 28,5 & 424,8 \\
\hline 19-7-2014 & 15 & 48,3 & 28,2 & 328,4 & 53,2 & 28,3 & 434,6 \\
\hline 20-7-2014 & 16 & 53,2 & 28,1 & 378,5 & 57,8 & 28,1 & 432,8 \\
\hline 21-7-2014 & 17 & 55,2 & 27,5 & 376,4 & 59,8 & 27,6 & 421,0 \\
\hline $22-7-2014$ & 18 & 47,3 & 27,2 & 376,2 & 53,4 & 27,8 & 417,9 \\
\hline 23-7-2014 & 19 & 44,8 & 26,0 & 343,2 & 48,6 & 28,0 & 424,9 \\
\hline 24-7-2014 & 20 & 46,0 & 25,2 & 340,2 & 56,2 & 25,2 & 417,9 \\
\hline 25-7-2014 & 21 & 44,6 & 24,7 & 333,8 & 61,5 & 24,7 & 421,4 \\
\hline 26-7-2014 & 22 & 44,7 & 24,2 & 373,9 & 61,0 & 24,2 & 412,9 \\
\hline 27-7-2014 & 23 & 48,0 & 23,8 & 439,0 & 61,0 & 23,8 & 465,1 \\
\hline 28-7-2014 & 24 & 49,6 & 23,4 & 441,1 & 63,6 & 23,5 & 472,7 \\
\hline 29-7-2014 & 25 & 47,5 & 23,0 & 465,5 & 60,3 & 23,0 & 483,2 \\
\hline $30-7-2014$ & 26 & 48,4 & 22,5 & 484,2 & 58,3 & 22,5 & 505,6 \\
\hline $31-7-2014$ & 27 & 48,9 & 22,1 & 495,1 & 56,1 & 22,1 & 513,6 \\
\hline $1-8-2014$ & 28 & 50,4 & 21,8 & 503,9 & 58,9 & 21,8 & 518,8 \\
\hline 2-8-2014 & 29 & 51,3 & 21,7 & 520,2 & 59,3 & 21,7 & 530,9 \\
\hline 3-8-2014 & 30 & 51,1 & 21,3 & 539,5 & 58,5 & 21,3 & 548,0 \\
\hline 4-8-2014 & 31 & 52,7 & 21,0 & 557,3 & 58,9 & 21,0 & 574,4 \\
\hline 5-8-2014 & 32 & 52,6 & 20,7 & 578,2 & 59,5 & 20,7 & 597,5 \\
\hline $6-8-2014$ & 33 & 54,4 & 20,4 & 588,6 & 59,7 & 20,4 & 616,3 \\
\hline 7-8-2014 & 34 & 54,6 & 20,3 & 585,9 & 59,9 & 20,4 & 612,2 \\
\hline 8-8-2014 & 35 & 53,9 & 20,0 & 594,1 & 61,8 & 20,0 & 614,1 \\
\hline
\end{tabular}




\section{Vervolg Bijlage 5 Gerealiseerde temperaturen, relatieve luchtvochtigheden en ventilatie-}

debieten per klimaatcel

\section{Vierde ronde}

\begin{tabular}{|c|c|c|c|}
\hline Dagnummer & Stal $\mathrm{T}\left({ }^{\circ} \mathrm{C}\right)$ & RV (\%) & $\begin{array}{l}\text { Debiet ( } \mathrm{m}^{3} / \text { uur) } \\
\left(1,2 \mathrm{~m}^{3} / \mathrm{kg} \text { per uur) }\right.\end{array}$ \\
\hline 1 & 34,0 & 40,0 & 300 \\
\hline 2 & 33,3 & 41,7 & 300 \\
\hline 3 & 32,7 & 43,3 & 300 \\
\hline 4 & 32,0 & 45,0 & 300 \\
\hline 5 & 31,3 & 46,7 & 300 \\
\hline 6 & 30,7 & 48,3 & 300 \\
\hline 7 & 30,0 & 50,0 & 300 \\
\hline 8 & 29,8 & 51,4 & 300 \\
\hline 9 & 29,6 & 52,9 & 300 \\
\hline 10 & 29,4 & 54,3 & 300 \\
\hline 11 & 29,2 & 55,7 & 300 \\
\hline 12 & 29,0 & 57,1 & 300 \\
\hline 13 & 28,8 & 58,6 & 300 \\
\hline 14 & 28,6 & 60,0 & 300 \\
\hline 15 & 28,4 & 60,0 & 300 \\
\hline 16 & 28,2 & 60,0 & 300 \\
\hline 17 & 28,0 & 60,0 & 300 \\
\hline 18 & 27,3 & 60,0 & 300 \\
\hline 19 & 26,5 & 60,0 & 300 \\
\hline 20 & 25,8 & 60,0 & 300 \\
\hline 21 & 25,0 & 60,0 & 300 \\
\hline 22 & 24,6 & 60,0 & 300 \\
\hline 23 & 24,1 & 60,0 & 300 \\
\hline 24 & 23,7 & 60,0 & 300 \\
\hline 25 & 23,3 & 60,0 & 322 \\
\hline 26 & 22,9 & 60,0 & 345 \\
\hline 27 & 22,4 & 60,0 & 368 \\
\hline 28 & 22,0 & 60,0 & 391 \\
\hline 29 & 21,7 & 65,0 & 416 \\
\hline 30 & 21,4 & 65,0 & 440 \\
\hline 31 & 21,1 & 65,0 & 465 \\
\hline 32 & 20,9 & 65,0 & 490 \\
\hline 33 & 20,6 & 65,0 & 515 \\
\hline 34 & 20,3 & 65,0 & 541 \\
\hline 35 & 20,0 & 65,0 & 567 \\
\hline 36 & 19,8 & 70,0 & 593 \\
\hline 37 & 19,6 & 70,0 & 619 \\
\hline 38 & 19,5 & 70,0 & 646 \\
\hline 39 & 19,3 & 70,0 & 672 \\
\hline 40 & 19,2 & 70,0 & 698 \\
\hline 41 & 19,1 & 70,0 & 725 \\
\hline 42 & 19,0 & 70,0 & 751 \\
\hline
\end{tabular}




\section{Bijlage 6 Werkwijze boxmetingen project 4413801750 'Strooiselkwaliteit' - Klimaatstal DB-CVI}

In onderstaande figuur wordt de ijklijn gegeven voor gebruikte meetventilator in de meetbox.

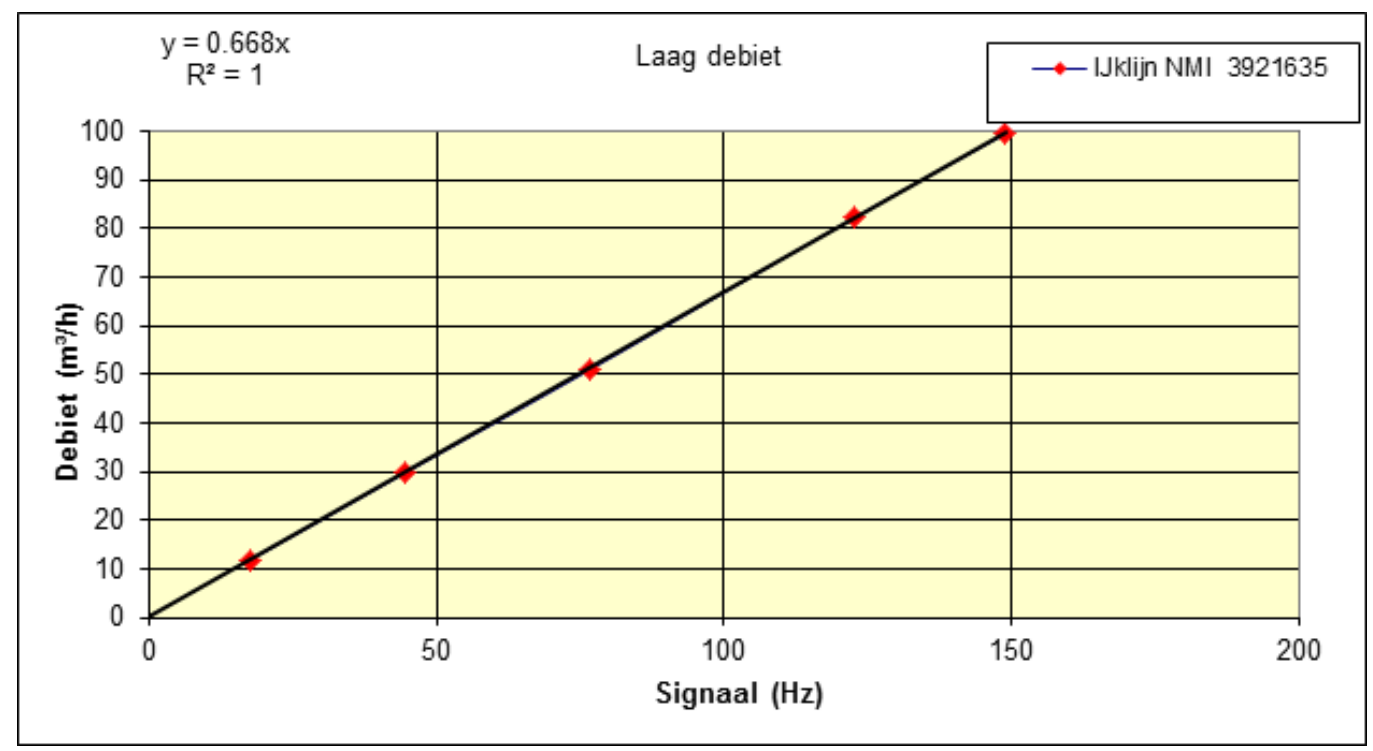

Figuur

IJ klijn van de gebruikte ventilator in de meetbox

De procedure voor het meten van de ammoniakemissie met behulp van de meetbox was als volgt:

1a Innova's alvast laten opwarmen (op elektriciteit aanzetten);

Graag beide Innova's voorafgaand aan de metingen gedurende 15 minuten inkomende lucht laten samplen.

1b Slang voor ingaande lucht van de meetbox uitrollen en bevestigen aan aansluitpunt wand.

Voorkom knikken in de flexibele slang.

Plaats het frame waarop meetbox moet komen in het hok en druk mesrand tot op betonvloer. Let er op dat het te bemeten oppervlak hierbij zo minimaal mogelijk wordt beroerd.

Werkwijze:

Aan begin van meetdag: plaats het eerste frame in het eerst te bemeten hok en plaats het tweede frame in het tweede hok. Na beëindiging meting eerste hok, verplaatst het frame naar het derde te bemeten hok, etcetera

2 Plaats meetbox zodanig in hok dat de opening ingaande lucht naar voor-/kleedruimte is gericht. Let erop dat tijdens de metingen de deur naar de kleedruimte gesloten is. Indien deur open is kan klimaat niet goed worden geregeld.

3 Sluit de tubes van Innova's aan op de ingaande en uitgaande buis van de meetbox. Gebruik altijd dezelfde Innova voor ingaande en uitgaande lucht. Noteer welke Innova's dit zijn!

$4 \quad$ Ventilator van de meetbox inschakelen; NOTEER op FORMULIER: de actuele tijd van Innova ingaande lucht (tx); de actuele tijd van de Innova uitgaande lucht; stopwatch starten ( $t x=0)$. (Of noteer tijd één van beide Innova's)

5 Controleer ventilator + meetventilator meetbox (afvinken op formulier). Streef naar een debiet van $20 \mathrm{~m} 3 /$ uur. Luchtsnelheid over strooisel zo minimaal mogelijk houden $(0,2 \mathrm{~m} / \mathrm{s})$ Opmerking: In de tweede ronde is er gewerkt met twee boxdebieten: 20 en $40 \mathrm{m3} / \mathrm{uur}$ Controleer na 4 minuten ( $x+4)$ met de flow(pulsenteller, beeldscherm). 
Bepaal na 8 minuten $(t x+8)$ met Kitagawa de NH3 concentratie van ingaande lucht via gaatje in slang meetbox. CONCENTRATIE en tijdstip NOTEREN OP FORMULIER. In geval van een lage ammoniakconcentratie ( $<1$ ppm), meerdere keren pompen, met een max. van vijf. NH3concentratie $=$ afgelezen concentratie / aantal keren pompen.

7b Bepaal na 10 minuten $(t x+10)$ met Kitagawa de $\mathrm{NH} 3$ concentratie van ingaande lucht via gaatje in slang meetbox. CONCENTRATIE en tijdstip NOTEREN OP FORMULIER

8 Controleer na 13 minuten $(t x+13)$ nogmaals de flow(visueel op beeldscherm).

9 Na $15(t x+15)$ minuten Innova meting beëindigen. Noteer de STOPWATCH TIJD (of tijd monitor) noteren op formulier op het moment van uitzetten.

10 De NH3 sampling tubes loskoppelen van de ingaande en uitgaande buis van de box. NOTEER op FORMULIER: de actuele tijd van Innova ingaande lucht; de actuele tijd van de Innova uitgaande lucht; EI NDTIJD STOPWATCH

11 Daarna (altijd als laatste) pas de ventilator van de meetbox uit

12 Verplaats de meetbox naar het volgend hok. Let er hierbij op dat de meetveldjes bij het verplaatsten zo minimaal mogelijk worden beroerd.

13 Bemonstering strooisel in de rechthoek waar de meetbox net verwijderd. Neem hierbij een op twee plaatsen (diagonaal) een monster tot op betonvloer. Monsters in plastic zakje doen (Codering: Datum + hoknummer)

Let op: Strooiselmonster behoeven alleen op de eerste meetdag van een week te worden verzameld. Gebruik voor de monstername een mestboor (conservenblik) met een diameter van ca. $10 \mathrm{~cm}$.

\section{Werkvolgorde}

Meetdag 1 (donderdag)

Meet eerst hok 1 - 4 (afdeling 30), vervolgens hok 9 - 12 (afdeling 32), vervolgens hok 5 - 8 (afdeling 30) en tenslotte hok 13 - 16 (afdeling 32).

Meetdag 2 (vrijdag)

Meet eerst hok 9 - 12 (afdeling 32), vervolgens hok 1 - 4 (afdeling 30), vervolgens hok 13 - 16 (afdeling 32) en tenslotte hok 5 - 8 (afdeling 30).

De NH3-concentratie van de ingaande lucht zal tevens nat-chemisch worden vastgesteld. Hiertoe zal gedurende de gehele meetdag (08:00u - 16:00u) de inkomende lucht gesampled worden. 


\section{Bijlage 7 Productieresultaten per voerprogramma (Ronde 3 en 4)}

Tabel B8.1 Effect voerprogramma op de productieresultaten van vleeskuikens 0 - 35 dagen (ronde 3)

\begin{tabular}{lrrrr} 
& Normaal re & $\begin{array}{c}\text { Normaal re / } \\
\text { Kenmerk }\end{array}$ & Hoog re / & Hoog re / \\
\hline Begingewicht $(\mathrm{g})$ & 42 & 42 & 43 & 43 \\
\hline Eindgewicht $(\mathrm{g})$ & 2398 & 2270 & 2476 & 2363 \\
\hline Groei D0_35 $(\mathrm{g})$ & 2356 & 2228 & 2433 & 2321 \\
\hline Uitval D0_35 $(\%)$ & 2,0 & 5,0 & 4,0 & 9,0 \\
\hline Voerconversie $(\mathrm{g} / \mathrm{g})$ & 1,408 & 1,394 & 1,389 & 1,408 \\
\hline Voerverbruik $(\mathrm{g})$ & 3316 & 3106 & 3380 & 3267 \\
\hline Water/voer & 1,57 & 1,77 & 1,76 & 1,87 \\
\hline Waterverbruik $(\mathrm{ml})$ & 5221 & 5518 & 5964 & 6099 \\
\hline Voetzoollaesiescore & 2 & 28 & 39 & 53 \\
\hline Hakdermatitisscore & 0 & 8 & 10 & 36
\end{tabular}

Tabel B8.2 Effect voerprogramma op de productieresultaten van vleeskuikens 0 - 42 dagen (ronde 4)

\begin{tabular}{lrrrr} 
Kenmerk & Laag re / & Laag re / Normal K & Normaal re / & Normaal re / \\
Leagingewicht $(\mathrm{g})$ & 45 & 44 & 44 & 45 \\
\hline Eindgewicht $(\mathrm{g})$ & 3085 & 2937 & 3180 & 2980 \\
\hline Groei D0_35 (g) & 3040 & 2893 & 3136 & 2936 \\
\hline Uitval D0_35 (\%) & 2,1 & 3,1 & 7,3 & 4,2 \\
\hline Voerconversie (g/g) & 1,571 & 1,637 & 1,571 & 1,582 \\
\hline Voerverbruik $(\mathrm{g})$ & 4777 & 4731 & 4924 & 4644 \\
\hline Water/voer & 1,60 & 1,71 & 1,67 & 1,70 \\
\hline Waterverbruik (ml) & 7622 & 8096 & 8208 & 7914 \\
\hline Productiegetal & 451 & 408 & 446 & 423 \\
\hline Voetzoollaesiescore & 2 & 28 & 39 & 53 \\
\hline Hakdermatitisscore & 0 & 8 & 10 & 36 \\
\hline
\end{tabular}





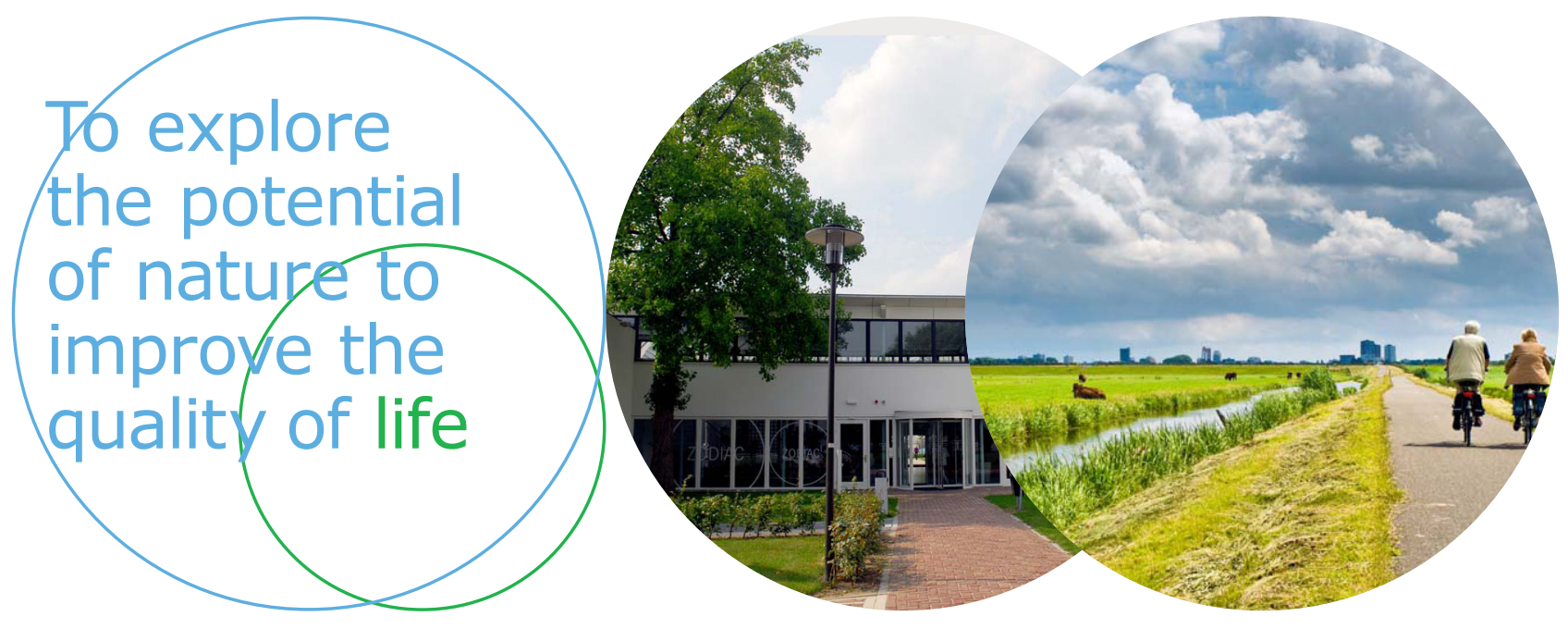

Wageningen Livestock Research Postbus 338

Wageningen Livestock Research ontwikkelt kennis voor een zorgvuldige en $6700 \mathrm{AH}$ Wageningen

T 0317483953

renderende veehouderij, vertaalt deze naar praktijkgerichte oplossingen en innovaties, en zorgt voor doorstroming van deze kennis. Onze wetenschappelijke E info.livestockresearch@wur.nl www.wur.nl/ livestock-research kennis op het gebied van veehouderijsystemen en van voeding, genetica, welzijn en milieu-impact van landbouwhuisdieren integreren we, samen met onze klanten, tot veehouderijconcepten voor de $21 \mathrm{e}$ eeuw.

De missie van Wageningen University \& Research is 'To explore the potential of nature to improve the quality of life'. Binnen Wageningen University \& Research bundelen 9 gespecialiseerde onderzoeksinstituten van Stichting Wageningen Research en Wageningen University hun krachten om bij te dragen aan de oplossing van belangrijke vragen in het domein van gezonde voeding en leefomgeving. Met ongeveer 30 vestigingen, 6.500 medewerkers en 10.000 studenten behoort Wageningen University \& Research wereldwijd tot de aansprekende kennisinstellingen binnen haar domein. De integrale benadering van de vraagstukken en de samenwerking tussen verschillende disciplines vormen het hart van de unieke Wageningen aanpak. 